\title{
EL ACOSO EN EL TRABAJO: ALGUNOS ASPECTOS DOCTRINARIOS, JURISPRUDENCIALES Y LEGALES DEL ACOSO MORAL Y SEXUAL EN CHILE
}

\author{
Álvaro Eduardo Domínguez Montoya* \\ Abogado \\ Patricio Eleodoro Mella Cabrera** \\ Universidad de Concepción \\ Rodolfo Teodoro Walter Díaz ${ }^{* * *}$ \\ Universidad de Concepción
}

\begin{abstract}
RESUMEN: La conducta de apremio o persecutoria podemos denominarla "Conducta de hostigamiento", la cual es de particular interés para el derecho del trabajo en los casos en que se produce un asedio dentro de la relación laboral y hostigamiento y con ocasión de su término, distinguiéndose entre hostigamiento o acoso laboral y hostigamiento o acoso sexual, hipótesis lesivas para los intervinientes en la relación de trabajo y en particular de los derechos fundamentales. Si bien, las conductas en ambas instituciones tienen algunas coincidencias (asedio del hechor, ausencia de consentimiento de la víctima y el perjuicio en el empleo u ocupación), se reconocen relevantes diferencias. Así, en el acoso laboral, el hostigamiento no tiene por finalidad obtener algún favor sexual, y además debe tener una cierta periodicidad o duración más o menos extendida en el tiempo. En cambio, en el acoso sexual un solo hecho que revista gravedad suficiente puede satisfacer el ilícito laboral, sin que sea necesario una repetición o duración más o menos prolongada. El trabajo desarrolla ambas hipótesis de hostigamiento laboral, refiriéndose a su regulación, concepto, infracción a los derechos fundamentales y otras infracciones, elemento, características y recepción de estas instituciones en la jurisprudencia y doctrina.
\end{abstract}

Palabras clave: Hostigamiento en el trabajo - acoso laboral y sexual

ABSTRACT: The conduct of enforcement or persecution can call it "Conduct of harassment", which is of particular interest for the right to work in the cases in which a siege within the employment relationship and harassment occurs and during its term, distinguishing between harassment or workplace harassment and harassment or sexual harassment, hypothesis prejudicial for those involved in the relationship of work and in particular of fundamental rights. While attitudes in both institutions have some overlap (siege of the hechor, absence of consent of the victim and the prejudice in employment or occupation), relevant differences are recognized. Thus, in the workplace harassment, harassment not aims to obtain a sexual favor, and must also have a certain regularity or more or less extended duration in time. Instead, in the sexual harassment a single fact that magazine sufficient severity can satisfy the illicit labour, without requiring a repeated or more or less prolonged duration. The work develops both hypotheses of harassment labour, referring to its regulation, concept, violation of fundamental rights and other violations, element, features and reception of these institutions in the jurisprudence and doctrine.

Key words: Harassment at work - work and sexual harassment

\footnotetext{
Licenciado en Ciencias Jurídicas y Sociales por la Universidad de Concepción; Estudiante [2014-2015] en Màster en Drets Sociolaborals, Universitat Autónoma de Barcelona. España. Contacto: aedodominguez@gmail.com

* Abogado. Magíster en Derecho y Licenciado en Ciencias Jurídicas y Sociales por la Universidad de Concepción. Profesor de Derecho del Trabajo, Facultad de Ciencias Jurídicas y Sociales, Universidad de Concepción. Contacto: patmella@udec.cl

*** Abogado, Doctor y Magíster en Derecho por la Universidad Nacional de Rosario, Argentina. Licenciado en Ciencias Jurídicas y Sociales por la Universidad de Concepción; profesor de Derecho de Trabajo, Facultad de Ciencias Jurídicas y Sociales, Universidad de Concepción. Contacto: twalter@udec.cl
} 
Álvaro Eduardo Domínguez Montoya, Patricio Eleodoro Mella Cabrera, Teodoro Rodolfo Walter Díaz / El acoso en el trabajo: algunos aspectos doctrinarios, jurisprudenciales y legales del acoso moral y sexual en Chile

\section{INTRODUCCION}

El tema que nos convoca - y aunque el estado legislativo nos diga otras cosa- "es tan antiguo como el trabajo" , siendo un fenómeno de larga data pero de reciente actualidad desde un punto de vista jurídico laboral, por cuanto evoca un fenómeno ligado a las relaciones desiguales de poder y los espacios que permiten el ejercicio de un tipo de violencia privada, encontrándose presente en toda forma de organización que reproduzca una estructura jerárquica normativa, agudizándose en la empresa por la organización del trabajo y la configuración de la relación de laboral que facilita el ejercicio de un poder muchas veces polimorfo y polivalente ${ }^{2}$.

Por lo mismo, "al margen de la sanción jurídica y de la mayor o menor admisibilidad social que se haya dado en cada caso siempre han existido conductas en las relaciones humanas en las que se acosaba al rival más débil, se sacrifica a un individuo en aras de la unidad del grupo (chivo expiatorio o cabeza de turco) o simplemente se redirigía la violencia que se sufría de la institución en la que se encontraban inmersos contra los nuevos miembros (caso de las novatada). El poder, como la vida, siempre quiere más, tiende a excederse" ${ }^{3}$, lo que se expresa en las relaciones laborales. Recordemos que "en el contrato de trabajo la subordinación no significa solamente que el trabajador está obligado a prestar el servicio al cual se comprometió, sino que debe prestarlo con sujeción personal al poder directivo del empleador, lo cual crea, en la relación de trabajo, un sometimiento jerárquico de la persona del trabajador a la persona del empleador que no se produce en los contratos civiles y mercantiles"4.

En este contexto, la vuelta de tuerca en la observación del Derecho del Trabajo viene dada por "la publificación de las relaciones privadas y el redimensionamiento de la persona"s lo que ha permitido redefinir las relaciones de trabajo y por lo mismo facilitar el desarrollo y conceptualización de figuras destinadas a la limitación de la violencia privada y los espacios abiertos a la arbitrariedad, cuestiones de las cuales deben arrancar cualquier estudio contemporáneo de las instituciones laborales.

La conducta de apremio o persecutoria podemos denominarla "Conducta de hostigamiento", la cual es de particular interés para el derecho del trabajo en los casos en que se produce un asedio dentro de la relación laboral y hostigamiento y con ocasión de su término, distinguiéndose entre hostigamiento o acoso laboral y hostigamiento o acoso sexual, ambas hipótesis lesiva para los intervinientes en la relación de trabajo. Sobre este punto, los tribunales del trabajo han tenido ocasión de pronunciarse respecto de si un hostigamiento debe calificarse de una u otra institución, según criterios que veremos más adelante.

Si bien, las conductas en ambas instituciones tienen algunas coincidencias (asedio del hechor, ausencia de consentimiento de la víctima y el perjuicio en el empleo u ocupación), es preciso reconocer que también existen relevantes diferencias. Así, en el acoso laboral, el hostigamiento no tiene por finalidad obtener algún favor sexual, y además debe tener una cierta periodicidad o duración más o menos extendida en el tiempo. En cambio, en el acoso sexual un solo hecho que revista gravedad suficiente puede satisfacer el ilícito laboral, sin que sea necesario una repetición o duración más o menos prolongada.

\footnotetext{
Dejours, C. Trabajo y violencia. Cuando la injusticia se hace banal. Madrid, España: Modus Laborandi, 2009, p. 9.

2 Foucault, Michel. La verdad y las formas jurídicas. Barcelona, España: Gedisa, 2005, pp. 141 y 142.

3 Urrutikoet xea Barrutia, Mikel. Acoso Laboral y Lesión de Derechos Fundamentales. Madrid, España: Boromarzo, 2014, p. 25.

4 Uriarte, Óscar; Hernández, Oscar. "Crítica de la Subordinación. Parte I" en: Revista Laboral Chilena, Abril. Santiago, Chile,

$5 \quad$ Ibid., p. 17.
} 2002 . 
A continuación desarrollaremos ambas hipótesis de hostigamiento laboral:

\section{EL ACOSO MORAL EN MATERIA LABORAL}

\subsection{Aspectos Generales}

Si bien el tema de estudio es abordado desde una perspectiva jurídica- se debe hacer una observación gravitante en la comprensión del acoso laboral como instituto y es que "se trata de una hipótesis cuyo origen no se encuentra en el campo del derecho, sino de la etología, psiquiatría y la psicología", , por lo que su estudio, interpretación y aplicación desde lo jurídico necesariamente debe hacerse desde lo sociolaboral. Recordemos que "el enemigo número uno del Derecho del Trabajo es la abstracción o el esquematismo"'. En tal esquema, se debe ser desconfiado y crítico en la confluencia de ambos predicados, ya que el reconocer las particularidades del acoso desde el punto de vista de la psicología y psiquiatría irrestrictamente, puede generar inconvenientes en su coexistencia con cuestiones estrictamente jurídicas -computo de plazos, bienes jurídicos protegidos, forma de afectación, prueba, daño, tipicidad, entre otros- lo que más que ayudar en el tránsito de la tutela del acoso moral en las relaciones de trabajo lo entramparía.

Por lo mismo, creemos que se debe ser doblemente cuidadoso y no pecar -como de costumbredesde la soberbia autorreferencial del Derecho ${ }^{8}$ pero tampoco aceptar, sin mayor reflexión, una conceptualización estrictamente sicológico/psiquiátrica del acoso moral, debiendo ser el norte en tal confluencia, la tutela de los derechos fundamentales en las relaciones de trabajo, como apuntaremos más adelante.

En tal esquema, buscando los orígenes explicativos del acoso, estos pueden ubicarse en la etología, en particular en los estudios realizados por Konrad LoREnz, quien introduce el concepto de Mobbing al analizar el comportamiento agresivo de un grupo de animales pequeños (aves), que acosaban a un animal solitario, mayor, con el objetivo de que abandonase su territorio, mediante actos indirectos no frontales, de hostigamiento sistemático, de perturbación reiterada, que obtenía como resultado el agotamiento de la resistencia del animal que finalmente terminaba por marcharse voluntariamente del territorio ${ }^{9}$. Esta última categoría fue trasladada al análisis de las relaciones sociales por parte Peter-Paul Heinemann, quien interesado en el comportamiento social infantil fuera del aula, tomó prestado el término para identificar un comportamiento colectivo de niños sobre individuos aislados, que se comportaban de manera similar a las conductas observadas por LORENZ ${ }^{10}$.

Posterior a lo anterior -y curiosamente sin relación a los estudios indicados-, aparece en EEUU los primeros acercamientos del Mobbing al mundo del Trabajo, realizados por Carrol Bro-

\footnotetext{
6 Gamonal Contreras, Sergio; Prado López, Pamela. El mobbing o acoso mora laboral. Santiago, Chile: Lexis Nexis, 2006, p. 7.

7 Camerlynk, G.H.; Lyon- Caen. Derecho del Trabajo. Madrid, España: Editorial Aguilar, 1974, p. 5.

8 Diría Javillier, Jean-Claude: "las reglas del Derecho del Trabajo no se pueden aislar de su contexto: el jurista debe dar prueba de gran humildad", todo lo anterior a propósito del "método de análisis" y la autorreferencia epistemológica del derecho, afirmando el autor en páginas posteriores que "ninguna disciplina concreta es capaz, pese a su entidad, de captar todos los aspectos del análisis social, es porque la naturaleza del análisis social requiere de un método de síntesis". JAVILLIER, Jean-Claude. Derecho del Trabajo. Madrid, España: Edición de Instituto de Estudios Laborales y Seguridad Social, 1982, pp. 28 y ss.

- Ver LoRenz, Konrad. El comportamiento animal y humano. Barcelona, España: Plaza \& Janés, 1985; Sobre la agresión: el pretendido mal. Madrid, España: Siglo veintiuno de España, 1985.

10 Ver Heinemann, Peter-Paul. Mobbning-grupvald bland barn och vuxna. Estocolmo, Suecia: Natur och kultur, 1972.
} 
Álvaro Eduardo Domínguez Montoya, Patricio Eleodoro Mella Cabrera, Teodoro Rodolfo Walter Díaz / El acoso en el trabajo: algunos aspectos doctrinarios, jurisprudenciales y legales del acoso moral y sexual en Chile

DSKY, el cual fue presentado de manera expositiva en un conjunto de materias sobre accidentes laborales y episodios de estrés, sin hacer una mayor profundización en el desarrollo del mismo ${ }^{11}$. No obstante, el salto en tal conducta en materia laboral, es realizado por HEINz LEYMANN quien imprime un desarrollo al estudiar ciertas situaciones de hostigamiento en el marco de las situaciones laborales ${ }^{12}$, concluyendo que el sicoterror o mobbing en la vida laboral importa una comunicación hostil y desprovista de ética que es administrada de manera sistemática por uno o unos pocos sujetos, principalmente contra un único individuo, quien a consecuencia de esto, es lanzado a una situación de soledad e indefensión prolongada, a base de acciones de hostigamiento frecuentes y persistentes (por lo menos una vez por semana) y a lo largo de un prolongado período (al menos durante seis meses). Para este autor, el acoso es detectable mediante una comparación de la conducta del hostigador, con alguna o varias de las conductas que se estima constitutiva de acoso, a las que se suelen agregar los elementos de repetición y temporalidad ${ }^{13}$.

En términos lingüísticos, no es baladí indicar que existe una disparidad terminológica y conceptual para referirse al acoso moral, reflejando distintos ángulos de observación y diversas cargas culturales. Con intención aclarativa, haremos un repaso de alguna de ellas.

El primer término empleado fue el de "mobbing", neologismo creado a partir del inglés "to mob" que evoca la expresión abalanzarse, perseguir y que se usó en sentido de violencia psicológica laboral en 1984 por primera vez por LEYMANN ${ }^{14}$. Igualmente se ha indicado una serie de anglicanismos para designar distintas hipótesis de acoso como bossing, bullying y harassment ${ }^{15}$ las cuales más que aclarar confunden por su poco desarrollo técnico. De igual forma se ha designado para conceptualizar la materia en comento el concepto de "Acoso Moral"16, el que ha tenido una notable influencia y recepción

11 Ver Brodsky, Carroll. The Harassed Worker. D.C. Health and Company, Lexington, 1976.
12 Heinz Leymann confeccionó un inventario conocido mundialmente como LIPT (Leymann Inventory of Psychological Terrorization), en el cual se hace una distinción de las conductas atendiendo al objetivo o efecto hostigatorio buscado por el ofensor, así por ejemplo, se agrupan las primeras once conductas por ser Actividades de acoso para reducir las posibilidades de la víctima de comunicarse adecuadamente con otros, incluido el propio acosador, dentro de esta categoría se encuentran actividades como: 1) El jefe o acosador no permite a la víctima la posibilidad de comunicarse, 2) Se interrumpe continuamente a la víctima cuando habla, entre otras. Otro grupo está formado por Actividades de acoso dirigidas a desacreditar o impedir a la víctima mantener su reputación personal o laboral, $y$ dentro de esta clase tenemos conductas como las siguientes: 17) Se maldice o se calumnia a la víctima, 18) Se hacen correr cotilleos y rumores orquestados por el acosador o el gang de acoso sobre la víctima. De esta manera se desarrollan las 45 conductas agrupadas en cinco categorías. Actualmente, se señala que el LIPT ha sido desplazado por el NAQ (Negative Acts Questionnaire) desarrollado por EINARSEN y RAKNEs (1997). El NAQ proviene de la investigación sobre acoso psicológico o "bullying" en las escuelas. El cuestionario está compuesto por 22 ítems, cada uno de ellos redactado conductualmente.

13 Leymann, Heinz. "The mobbing Encyclopedia", disponible en www.leymann.se.; The content and development of Mobbing at work; European Journal of Work and Organizational Psychology, 1996, 5 (2), disponible y traducido al español por Francisco Fuentes, en www.ste.uji.es, pp. 5 y 6.

14 Dejando patente que el concepto fue desarrollado primeramente en la etología por LORENZ y posteriormente por HEINEMANN en el campo de las relaciones sociales.

15 El primero se utiliza en aquellos casos en que el acosador es el jefe dentro de la empresa, diferenciando entre corporate bullying (acoso empresarial), serial bullying (cuando es realizado por compañeros de trabajo), gang bullying (si es ejecutado por un grupo frente a un individuo aislado) y, finalmente, client bullying, cuando la agresión es perpetrada por el cliente o usuario del servicio. Por su parte, el segundo es utilizado como es sinónimo de acoso, o mobbing con algún matiz, ya que ambas figuras hacen énfasis en aspectos diferentes de estas conductas. En el mob-bing parece hacerse hincapié en el proceso de victimización que sufre una persona y en las consecuencias negativas que sufre. En bullying se enfatiza más el papel de agresor y sus actos nocivos. El primero se visualiza más como acoso horizontal y el segundo se acerca más al vertical descendente. En las fuentes comunitarias en ingles parece usarse bullying como intimidación y harassment como acoso. URRUTIKoETXEA BARRUTIA, Mikel, op.cit. (n. 3), p. 34.

16 Utilizado principalmente por Hirigoyen, Marie-France. 
por parte de lo jurídico ${ }^{17}$, particularmente por que se "enlaza tanto con el concepto de daño moral como con el derecho a la integridad moral; conceptos ambos claves para la correcta compresión del fenómeno del hostigamiento laboral"18. De igual forma se ha utilizado la expresión "presión laboral tendenciosa", "acoso psicológico" y "psicoterror laboral" para referirse al mismo fenómeno.

En términos lingüísticos, la palabra "acoso"19 sugiere una conducta de apremio y persecutoria al definirse como "perseguir, apremiar, importunar a alguien con molestias o requerimientos", la que introducida al ámbito de las relaciones laborales -bajo la fórmula de moral o psicológico- sindica una "práctica ejercida en las relaciones personales, especialmente en el ámbito laboral, consistente en un trato vejatorio y descalificador hacia una persona, con el fin de desestabilizarla psíquicamente"20.

Pasando derechamente al concepto de Acoso Moral, Marie-France Irigoyen lo define como "cualquier manifestación de una conducta abusiva y, especialmente, los comportamientos, palabras, actos, gestos y escritos que puedan atentar contra la personalidad, la dignidad o la integridad física o psíquica de un individuo, o que puedan poner en peligro su empleo, o degradar el clima de trabajo"21.

Por su parte PiÑel y ZaBALA, indican que es:

"El deliberado y continuado maltrato moral y verbal que recibe un trabajador, hasta entonces válido, adecuado, o incluso excelente en su desempeño, por parte de uno o varios compañeros de trabajo (incluido muy frecuentemente el propio jefe), que buscan con ello desestabilizarlo y minarlo emocionalmente con vistas a deteriorar y hacer disminuir su capacidad laboral o empleabilidad y poder eliminarlo así más fácilmente del lugar y del trabajo que ocupa en la organización"22.

Los estudios de las distintas áreas relacionadas con la materia, han tratado de encontrar las causas detrás de este tipo de conductas, poniendo principalmente relieve entre conducta de acoso y los factores que determinan la organización de trabajo en una empresa. En tal caso:

"El acoso se ve favorecido en aquellas organizaciones que incentivan o se muestran indulgentes ante los estilos de dirección autoritarios y/o en las que los trabajadores están sometidos a un considerable grado de estrés, bien como consecuencia de las altas exigencias laborales, bien por producirse deficiencias en la organización y gestión del trabajo que redundan en una falta de autonomía y comunicación en el desarrollo de la prestación laboral, así como en la aparición de situaciones conflictivas, que cuando no son debidamente solucionadas suelen degenerar en conductas de acoso"23.

\footnotetext{
17 Solo por ejemplificar, el término ha tenido recepción en las primeras sentencias del Tribunal Supremo Español, las iniciativas legales y el Derecho Comunitario Europeo.

18 Urrutikoetxea Barrutia, Mikel, op. cit. (n. 3), p. 39.

19 Real Academia Española. Diccionario de la lengua española -230 ed.-. Madrid, España, 2013.

$20 \quad$ Ibid.

21 Hirigoyen, Marie-France. El acoso moral. El maltrato psicológico en la vida cotidiana. Barcelona, España: Paidós, 1999, p. 48. En otra oportunidad lo definió como "toda conducta abusiva (gesto, palabra, comportamiento, actitud...) que atenta, por su repetición o sistematización, contra la dignidad o la integridad psíquica o física de una persona, poniendo en peligro su empleo o degradando el ambiente de trabajo" Hirigoyen, Marie- France. El acoso moral en el trabajo. Distinguir lo verdadero de lo falso. Barcelona, España: Paidós, 2001, p. 19.

22 Piñuel y Zabala, Iñaki. Mobbing: cómo sobrevivir al acoso psicológico en el trabajo. Bilbao, España: Sal Terrae, 2001.

23 Jurado Segovia, Ángel. Acoso Moral en el Trabajo. Madrid, España: Editorial la ley, 2008, p. 34. Indica Piñuel sobre una de las causas del acoso que "una explicación muy frecuente es la de dar un escarmiento y hacer que otros trabajadores queden impresionados por el poder discrecional de hostigar y dañar que tiene algunos en la organización. Se trata de hacer cundir el
} 
Álvaro Eduardo Domínguez Montoya, Patricio Eleodoro Mella Cabrera, Teodoro Rodolfo Walter Díaz / El acoso en el trabajo: algunos aspectos doctrinarios, jurisprudenciales y legales del acoso moral y sexual en Chile

Igualmente se ha afirmado que constituye un factor determinante aquellas hipótesis de "conflictos abiertos" personales no verbalizados y soterrados no resueltos ${ }^{24}$, como así también envidias y rivalidades tanto personales como profesionale ${ }^{25} \mathrm{y}$ de igual forma factores estrictamente psicológicos-patológicos del sujeto agresor (personalidad maligna, mediocridad inoperante activa, personalidad sicopática agresiva, psicopática o antisocial, narcisista, paranoide ${ }^{26}$, o incluso - y en el plano que se desarrolla este trabajo- la escasa configuración normativa o jurisprudencial de los sistemas jurídicos frente a la tutela del hostigamiento laboral, donde al no existir canales jurídicos formales que permitan la protección del trabajador -ya sea mientras la relación de trabajo este vigente o bien buscando mecanismos de términos que junto con reparar el daño sufrido sancionen al acosador- los que por el contrario, en la omisión favorecen el ejercicio de la violencia privada mediante tales prácticas ${ }^{27}$. Sería imposible plantear todas las explicaciones y causas que se han dado al respecto por ser estas inagotables pero creemos que las anteriores exteriorizan la variedad de factores y causas que originan el acoso moral.

En tal contexto, el hostigamiento laboral es un proceso de destrucción que se compone de una serie de actuaciones hostiles que, tomadas de manera aislada, podrían parecer anodinas o sin importancia, pero cuya repetición constante tiene efectos perniciosos con el fin de destruir las redes de comunicación o reputación de la víctima o víctimas y de perturbar el ejercicio de sus labores hasta que finalmente acaben por abandonar el lugar de trabajo ${ }^{28}$, por lo que se destaca que "el acoso no se define tanto por los comportamientos llevados cabo, que por sí solos pueden parecer anodinos, cuanto por la frecuencia y duración de los ataques. El acoso se diferencia del mero conflicto o ataque puntual porque es un proceso, y ese proceso es el que genera los efectos perniciosos que caracterizan a este tipo de conductas"29.

Por lo mismo en general ${ }^{30}$, se distinguen diversas etapas o fases sobre el acoso laboral, tanto desde un punto de vista organizacional ${ }^{31}$ como desde el punto de las víctimas ${ }^{32}$.

Señala Piñuel y Zabala -siguiendo a LeymmanN- una secuencia típica de cinco fases. En una primera etapa (de incidentes críticos), existe una relación normal en la que se suele observar

psicoterror laboral entre otros trabajadores, que habrán de cerrar filas, presas del terror ante lo que les podría ocurrir de no someterse a los dictados del grupo que hostiga". PIñuel y ZABALA, Iñaki. Mobbing. Manual de autoayuda. Madrid, España: Aguilar, 2003, p. 65

24 Indica la autora, apostando por las virtudes de la tesis conflictual, que "si hay acoso moral, es precisamente porque no se ha conseguido establecer un conflicto". Agrega la autora que "un conflicto es una fuente de renovación y de reorganización que obliga a cuestionarse y a funcionar según formas nuevas. Permite movilizar las energías y unir a las personas, modificar las alianzas, expresar las complejidad y, sobre todo, aportar un poco de animación y de novedad a contextos profesionales demasiados rutinarios". Indica finalmente que "querer evitar los conflictos a cualquier precio es, pues, un error, ya que constituyen momentos en que podemos cambiar y tener en cuenta al otro, es decir, enriquecernos. A diferencia del conflicto, el acoso moral es una manera de bloquear cualquier cambio". Hirigoyen, Marie- France, $E l$ acoso moral en el trabajo... (n. 21), pp. 25 y ss.

25 Piñuel y Zabala, Iñaki, Mobbing. Manual... (n. 23), p. 64.

26 Piñuel y Zabala, Iñaki, Mobbing. Cómo sobrevivir al acoso... (n. 22), pp. 151 y ss.

27 Jurado Segovia, Ángel, op. cit. (n. 23), p. 35.

28 Romanik Foncea, Katy. El mobbing y su tratamiento en la legislación laboral. Informe de Actualidad Laboral $\mathrm{N}^{\circ} 2$. Santiago, Chile: Departamento de Estudios, Dirección del Trabajo, 2011, p. 9.

29 Jurado Segovia, Ángel, op. cit. (n. 23), p. y, 2008, p. 37.

30 Abajo Olivares, Francisco Javier. Mobbing: El acoso psicológico en el ámbito laboral. Buenos Aires, Argentina: Editorial Depalma, 2004, p. 41 y ss. y PiÑuel y Zabala, Iñaki, Mobbing. Manual... (n. 23), p. 66 y ss.

31. Se habla generalmente de a) Fase de conflictos o de incidentes críticos; b) Fase de acoso y estigmatización; c) Fase de intervención de las autoridades de la empresa; d) Fase de solicitud de ayuda especializada externa y diagnóstico incorrecto e) Fase de exclusión o marginación de la vida laboral.

32 Comúnmente se dice que estas son: a) Fase inicial de acoso; b) Fase de conflicto abierto y c) Fase de escape. 
"un desencuentro entre personas que en un momento determinado adquiere mayor proporción, presentándose la imagen de un conflicto puntual que comienza en una escalada"; en la segunda etapa (estigmatización) se comienzan a materializar las conductas de acoso, donde éste se "desarrolla mediante comportamientos repetidos que en otro contexto distinto al acoso no revestirían mayor importancia ni implicarían agresión ni intentos de excluir o de deshacerse de alguien", no obstante acá se observa "una intencionalidad perversa, proceso de intención consistente en ir a por el otro, perjudicarle, castigarle, minimizarle psicológicamente"; en la tercera fase (de intervención de la dirección), hace alusión a cuando la gerencia o planta directiva toma conocimiento de la situación que se produzca y se adopten las medidas necesarias de protección, no obstante que la efectividad de la misma puede no darse, siendo incluso el acosado el problema, asumiendo el empleador una conducta pasiva al respecto. "La línea jerárquica suele cerrar filas y tender a aceptar y a hacer propios los prejuicios u estereotipos proyectados"; una cuarta fase (solicitud de ayuda especializada externa y diagnóstico incorrecto) se refiere a la solicitud de ayuda especializada psicológica por motivo de las consecuencias generadas por el acoso en la que incluso se puede observar un diagnóstico erróneo basado en sus características personales, con lo que su sufrimiento se ve incrementado aún más al hacerle sentirse responsable de su propio acoso psicológico. En este examen se suele diagnosticar estrés, depresión, burn-out, personalidad paranoide, maníacodepresión o ciclotimia; desajuste de personalidad, trastornos de ansiedad, ataques de pánico; una quinta fase (salida o expulsión de la organización) se produce un resultado perjudicial para la víctima, ya que frente a la ausencia de soluciones concretas y en un entorno hostil se carece de canales de comunicación y solución, se produce el abandono de su puesto de trabajo, ya sea de manera directa mediante la renuncia o abandono o bien mediante fórmulas indirectas como bajas intermitentes o continuas, que van desde extensas licencias médicas o absentismo laboral ${ }^{33}$.

\subsection{El Acoso Moral y su Recepción en el Derecho del Trabajo}

En los últimos años hemos sido testigos de un proceso reduccionista del Derecho del Trabajo mediante políticas y prácticas desreguladoras/flexibilizadoras, pero también, como contrapartida, hemos observado una resignificación de la importancia de la personalidad del trabajador en la relación de trabajo.

En tal esquema la recepción de los denominados derechos fundamentales inespecíficos ha sido considerado uno de los fenómenos más trascendentes en lo que se refiere a las relaciones asalariadas acaecido en los últimos años ${ }^{34}$, siendo tal idea la matriz fundamental en el desarrollo de los diversos tipos de acoso laboral en las relaciones de trabajo y que influye decisivamente en la configuración tipológica del mismo.

En general y como lo mencionamos anteriormente, el Derecho debe adecuar de la mejor forma posible el concepto de Acoso Moral al espacio normativo, so pena de generar instituciones que, inversamente a lo deseado, dificulten la tutela frente a tales conductas de hostigamiento. Indica sobre el punto UGARTE algunas de estas aprensiones, en el sentido de parecer:

"Razonable sostener que debería transitarse desde una traslación automática del concepto de acoso laboral, a una relación reflexiva de la interacción entre Psicología y Derecho del

\footnotetext{
33 Piñuel y Zabala, Iñaki, Mobbing. Manual ... (n. 23), p. 66 y ss. Esta misma clarificación es realizada en idénticos términos por Gamonal Contreras, Sergio; Prado López, op. cit. (n. 6), p. 17.

${ }^{34}$ Ver Palomeque, Manuel, Los derechos laborales en la Constitución española. Madrid, España: Centro Estudios Constitucionales, 1991.
} 
Álvaro Eduardo Domínguez Montoya, Patricio Eleodoro Mella Cabrera, Teodoro Rodolfo Walter Díaz / El acoso en el trabajo: algunos aspectos doctrinarios, jurisprudenciales y legales del acoso moral y sexual en Cbile

trabajo. Especialmente reflexiva en torno a la construcción de la noción de acoso laboral en torno a dos cuestiones fundamentales: primero, qué elementos deben ser considerados en la construcción del tipo de acoso laboral que se quiere reprimir, y segundo, la conveniencia de construir un ilícito de actividad o en cambio, de resultado"35.

Por lo mismo, haciendo un panóptico meramente enunciativo, se producen determinados problemas cuando se transita de una configuración jurisprudencial-doctrinaria a una legal ${ }^{36}$ que acoge -con mayor o menor intensidad y sin mayor reflexión- los postulados de otras ciencias sin observar su interacción con la epistemología del Derecho y su funcionamiento, lo que deviene en que muchas veces la conceptualización legal lleva más desventajas que beneficios, generando un concepto de "carácter polimórfico" de "contornos difusos e imprecisos", en el que incluso se incluyen elementos subjetivos como "la finalidad" o un resultado asociado estrictamente al "daño en la salud"37, lo que como ya sabemos, más que maximizar la tutela frente a las conductas de acoso la disminuye.

Dentro de tal proceso y reconociendo las vicisitudes de la relación laboral, la incorporación a los sistemas de regulación de la noción de acoso moral se encuentra presente en la mayoría de los ordenamientos jurídicos, con las particularidades legislativas, doctrinarias, jurisprudenciales y culturales de

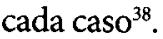

A nivel internacional podemos observar que la Organización Internacional del Trabajo ha observado este tipo de comportamiento dentro de figuras genéricas rotuladas como "violencia en el trabajo"39, generando un repertorio no vinculante de recomendaciones de carácter práctico para combatir la violencia en los espacios laborales ${ }^{40}$, como así también algunos textos que hacen expresa mención al combate del acoso laboral ${ }^{41}$, no obstante que hasta la fecha no existe algún tipo de convenio o recomendación referida al tema en particular.

Por su parte, en la Unión Europea se viene analizando el hostigamiento laboral desde hace un tiempo, inicialmente también bajo la idea de la violencia en el trabajo ${ }^{42}$, existiendo normas emanadas de Instituciones Comunitarias que han dictado una serie de directrices en el marco general de la seguridad y salud laboral, como así también de la igualdad en el trato en el empleo,

\footnotetext{
35 Ugarte, José Luis. "El acoso laboral: entre el Derecho y la Psicología", en: Revista de Derecho, No 39, pp. 221-231. Valparaíso, Chile: Escuela de Derecho, Pontificia Universidad Católica de Valparaíso, 2012.

${ }^{36}$ Tal es el caso del Derecho del Trabajo Español, por lo que su análisis -y en particular la configuración conceptual dada por la ley laboral- nos permiten extrapolar discusiones y problemas.

37. Urrutikoetxea Barrutia, Mikel, op. cit. (n. 3), p. 49 y ss.

38 Sobre el punto ver "Informe sobre Acoso sexual y moral en el lugar de trabajo" en: XX Congreso Mundial del Derecho del Trabajo y la Seguridad Social, realizado en Santiago, Chile, septiembre de 2012, co-relatores Gamonal, Sergio- UGARTE, José Luis, como así también los informes específicos por país. De igual forma ver Zarzalejo Carbajo, Mercedes, "El acoso moral en la experiencia comparada, internacional y comunitaria (I): concepto y responsabilidad jurídica"; SANTos Fernández, María Dolores, "El Acoso Moral en la experiencia comparada, internacional y comunitaria (II): prevención, reparación y represión de la conducta”, ambas obras En: Correa Carrasco, Manuel; VAldés de LA VEGA, Berta (Coords.). Los Medios de Tutela frente al Acoso Moral en el Trabajo. Granada, España: Comorales, 2007.

3y Ver Chapell, Duncan; Di MARTino, Vittorio. Violence at Work. Ginebra, Suiza: OIT, 1998.

40 Ver "Repertorio de recomendaciones prácticas sobre la violencia en el lugar de trabajo en el sector de los servicios y medidas para combatirla", reunión de expertos OIT 8-15 de octubre de 2003.

41 Entre otros documentos que marcan dicha tendencia ver "Directrices marco para afrontar la violencia laboral en el sector de la salud", OIT, Ginebra, 2002; y Convenio Colectivo sobre prevención y solución de reclamaciones en materia de acoso alcanzado en 2001 entre la Oficina de la OIT y el Sindicato de esta organización.

42 Ver Comisión de las Comunidades Europeas: 23 Informe Anual de Actividades del Comité Consultivo de Seguridad Higiene y Protección de la Salud en el Trabajo 1998, COM, Bruselas, 2000.
} 
dentro de las cuales podemos destacar la Resolución del Parlamento Europeo sobre acoso moral en el lugar de trabajo (2001/2339) (INI), de septiembre de 2001; directiva 2000/78/CE del Consejo Europeo, de 27 de noviembre, relativa a una marco general para la igualdad de trato en el empleo; directiva 2000/43/CE del Consejo, de 29 de junio de 2000, relativa a la aplicación del principio de igualdad de trato de las personas independientemente de su origen racial o étnico; Directiva 2002/73/CE del Parlamento Europeo y del Consejo, de 23 de septiembre de 2002, que modifica la Directiva 76/2007/CE del Consejo, relativa a la aplicación del principio de igualdad de trato entre hombres y mujeres, entre otras.

De manera resumida, podemos indicar que en el Derecho Comparado, los ordenamientos jurídicos han presentado atención a la temática del Acoso Moral de maneras muy distintas, adoptado un modelo de tipificación legislativa (civil y/o penal), de autonomía colectiva mediante instrumentos colectivos, incluso mediante instrumentos de gestión de Responsabilidad Social Empresarial mediante guías y código de conductas, o bien ante la ausencia de una normatividad en sentido estricto, ha sido la jurisprudencia y doctrina quien ha delimitado tal figura ${ }^{43}$.

En la doctrina comparada, SAGARDoY ${ }^{44}$ aludiendo a las Directivas de la Comunidad Europea, lo sindica "como un comportamiento no deseado (relacionado con el origen racial o étnico, la religión, las convicciones, la discapacidad, la edad, la orientación sexual o el sexo de una persona) que tenga como objetivo o consecuencia atentar contra la dignidad de la persona y crear un entorno intimidatorio, degradante, hostil, humillante y ofensivo".

Igualmente se ha dicho que el Acoso Moral -se utiliza por el autor el concepto de acoso laboral- son:

"Todos aquellos comportamientos, actos o conductas llevados a cabo por una o varias personas en el entorno laboral que, de forma persistente en el tiempo, tienen como objetivo intimidar, apocar, reducir, amilanar y consumir emocional e intelectualmente a la víctima, con vistas a forzar su salida de la organización o a satisfacer la necesidad patológica de agredir, controlar y destruir que suele presentar el hostigador como medio de reafirmación personal" 45 .

En la doctrina laboral nacional, CAAmaño lo define como un "comportamiento antijurídico, pluriofensivo de derechos fundamentales y está conformado por hostigamientos sistemáticos y reiterados de palabra, obra u omisión del empleador o de uno o más trabajadores, o de estos de consuno, contra uno o más trabajadores que atentan contra su dignidad o salud y afectan sus condiciones u oportunidades de empleo u ocupación"46. Por su parte, Gamonal y Prado lo conceptualizan como un:

\footnotetext{
43 Ver Zarzalejo Carbajo, Mercedes, op. cit. (n. 38), pp. 3 y ss y 16 y ss; Santos Fernández, María Dolores, op. cit (n. 38), pp. 41 y ss. Igualmente VAldés de la Vega, Berta. "El tratamiento del Acoso Moral desde la Autotutela Colectiva". En: Correa Carrasco, Manuel; Valdés de la Vega, Berta (Coords.). Los Medios de Tutela frente al Acoso Moral en el Trabajo. Granada, España: Comorales, 2007.

44 Sagardoy Bengoechea, Juan. Los derechos fundamentales y el contrato de trabajo. Navarra, España: Editorial Aranzadi, 2005 p. 94.

45 Cavas Martínez, Faustino. "El acoso moral en el trabajo (mobbing): Delimitación y herramientas para combatirlo", en: Actualidad Juridica Aranzadi, No 555, pp. 1-7. Madrid, España: Thomson Reuters, 2002, p. 3.

46 CaAmaño, Eduardo. "La noción de acoso laboral o mobbing y su reconocimiento por la jurisprudencia en Chile", en: Revista de Derecho, No 37, XXXVII, p. 228. Valparaíso, Chile: Escuela de Derecho, Pontificia Universidad Católica de Valparaíso, 2011.
} 
Álvaro Eduardo Domínguez Montoya, Patricio Eleodoro Mella Cabrera, Teodoro Rodolfo Walter Díaz / El acoso en el trabajo: algunos aspectos doctrinarios, jurisprudenciales y legales del acoso moral y sexual en Chile

"Proceso conformado por un conjunto de acciones $u$ omisiones, en el ámbito de las relaciones laborales pública y privadas, en virtud de las cuales uno o más sujetos acosadores crean un ambiente laboral hostil e intimidatorio respecto de uno o más acosados, afectando gravemente su dignidad personal y dañando la salud de o los afectados con miras a lograr distintos fines de tipo persecutorio" ${ }^{37}$.

Palavecino lo define como "los actos de agresión, múltiples y reiterados en el tiempo, instigados o ejecutados por el empleador, sus representantes y/o por uno o más compañeros de trabajo, que tienen como consecuencia producir un ambiente laboral degradante y dañino para la víctima"48.

\subsection{Regulación en el Ordenamiento Jurídico Chileno sobre el Acoso Laboral}

\subsubsection{La Ley No20607: el largo camino}

En nuestro país el concepto de acoso laboral ha sido objeto de un reconocimiento tardío en el ámbito legislativo ${ }^{49}$, puesto que a diferencia del acoso sexual, esta materia tuvo un reconocimiento jurisprudencial ${ }^{50}{ }_{-51}$ y doctrinario ${ }^{52}$ antes que legal ${ }^{53}$. El origen del acoso laboral se encuentra en

47 Gamonal, Sergio; Prado, Pamela, op. cit. (n. 6), pp. 22 y 23.

48 Palavecino Cáceres, Claudio. "La protección contra el Acoso Psíquico Laboral en el ordenamiento jurídico chileno", en: Revista de Derecho, vol.17, pp. 63-89. Valdivia, Chile: Facultad de Derecho, Universidad Austral de Chile, 2004.

49 Largo fue el tránsito a la incorporación como concepto legal a nuestro ordenamiento, siento la ley $N^{\circ} 20.607$ (publicada 8 de agosto de 2012) la que incorpora dicho concepto. Las discusiones legislativas sobre el punto pueden verse en "Proyecto de Ley que modifica el Código del Trabajo sancionando las prácticas de acoso laboral o psicoterror laboral", Boletín No $3198-13$ de 2003 y "Proyecto de ley que propone modificaciones al texto sobre acoso laboral", Boletín № 6212-13 de 2008.

50 La primera sentencia de la que tenemos conocimiento es aquella dictada por el $2^{\circ}$ Juzgado de Letras del Trabajo de Calama, de fecha 09 de mayo de 2005, Rol 38466-2005.

51 En tal sentido resolviendo conflictos laborales anterior a la reforma legal, acogiendo o rechazando la concurrencia de supuestos de una conducta de hostigamiento, ya sea durante la relación o con ocasión del despido, entre otros ver: Corte Suprema, Rol 8798-2010, 28 de Septiembre del 2010; Corte de Apelaciones de Valparaíso, Rol No 179- 2009, 16 de abril de 2009; Corte de Apelaciones de San Miguel, Rol No 65-2010, 3 de junio de 2010; Corte de Apelaciones de Talca, Rol 228-2010, 10 de Diciembre de 2010; Sentencia del Tribunal del Trabajo de Iquique, RIT T-20-2010 de fecha 27 de agosto de 2010; Sentencia del Tribunal del Trabajo de Temuco RIT T-4-2009, de fecha 2 de febrero de 2010; Sentencia del Tribunal del Trabajo de Valparaíso, RIT T-55-2009, de fecha 24 de febrero de 2010; Sentencia del Tribunal del Trabajo de Iquique, causa RIT T-12 2009, de fecha 28 de septiembre de 2009; Sentencia del Juzgado de Letras del Trabajo de Osorno RIT T-6-2010, de fecha 24 de septiembre de 2010; Sentencia del Juzgado de Letras del Trabajo de Temuco, RIT T-10-2012, 24 de Abril del año 2012; Sentencia del Juzgado de letras del Trabajo de San Antonio, fecha 28 de Junio del año 2012, causa RIT-1-2012; Sentencia 2० Juzgado de Letras del Trabajo de Santiago, RIT T-63-2009, 12 de febrero de 2010; Sentencia Juzgado de Letras de Iquique, RJT T-4-2008 del 20 de febrero de 2009.

52 Ya comentando la figura de acoso sexual en nuestro país antes de la entrada en vigencia de la Ley $\mathrm{N}^{\circ} 20.607$ (publicada 8 de agosto de 2012), entre otros: Prado López, Pamela, "Breves reflexiones en torno al mobbing", en: Revista Laboral Chilena, Julio, pp. 91-98. Santiago, Chile, 2005; Guid Moggia, Caterina. "El acoso moral o psicoterror en el ámbito laboral" (parte I y II), publicados en: Revista Laboral Chilena, Junio-Julio. Santiago, Chile, 2006; Gamonal Contreras, Sergio; Prado López, Pamela, op. cit. (n.6); CaAmaño, Eduardo. "La noción... (n. 46); Palavecino Cáceres, Claudio. "La protección contra... (n. 48); Planet Sepúlveda, Lucía. "Eficacia del procedimiento de tutela laboral como protección contra el Mobbing en Chile", en: Revista Chilena de Derecho del trabajo y de la Seguridad Social, vol.1 No 1, pp. 93-122. Santiago, Chile: Facultad de Derecho, Universidad de Chile.

53 Dicha realidad no es propia de nuestro país, sino que es un fenómeno globalizado propio del desfase del derecho ante lo socio laboral. Dicha situación es constatada en el Informe sobre "Acoso sexual y moral en el lugar de trabajo" en XX Congreso Mundial del Derecho del Trabajo y la Seguridad Social, realizado en Santiago, Chile, septiembre de 2012, en el que se indica que respecto al reconocimiento de la figura de acoso moral y si éste tiene reconocimiento: "En segundo lugar, se encuentra los países 
el planteamiento de casos que debieron ser resueltos por los tribunales laborales principalmente estimados como incumplimientos contractuales, cuya tipificación era de difícil encuadramiento entre las causales de terminación del contrato de trabajo. Esto produjo la atención de la doctrina en cuanto a proponer un esquema teórico que permitiera identificar este acoso dentro de la normativa laboral.

Así, las conductas de hostigamiento sufridas por el trabajador durante la prestación de sus servicios comienzan a instalarse dentro de la sociedad chilena como una cuestión relevante, lo que en opinión de algunos actores sociales debía enfrentarse legislativamente. Esta realidad motivó a un grupo de parlamentarios a proponer una iniciativa que lo regulara, al igual que el acoso sexual.

El escenario antes descrito propició el envío de un proyecto de ley que regulaba el acoso laboral en el curso del contrato de trabajo, que tenía como fundamento, el reconocimiento efectuado por la doctrina nacional e internacional, además de las legislaciones de la mayoría de los países, respecto del valor que se otorga a la dignidad de la persona humana, al respeto por ella y los derechos esenciales que emanan de la misma. En nuestro país dichos derechos fundamentales se encuentran garantizados en nuestra Constitución Política en sus artículos $1^{\circ} \mathrm{y} 5^{\circ}$, y en los Tratados Internacionales ratificados por Chile y que se encuentran vigentes ${ }^{54}$.

Esta moción parlamentaria enfrentó un largo período de discusión en el Parlamento chileno, cuya discusión no quedo exenta de críticas $^{55}$, en el que muchos doctrinadores veían innecesario ocuparse de esta reforma ${ }^{56}$, en cuanto entendían que las situaciones de acoso podían resolverse aplicando las fuentes usuales del Derecho del Trabajo, cuestión validada por diversos pronunciamientos tanto en materias e instancias típicamente laborales ${ }^{57}$ como en aquellas sustanciadas mediante mecanismos que no son estrictamente laborales e incluso ante Tribunales distintos a la Judicatura del Trabajo ${ }^{58}$.

\footnotetext{
-mayoritarios- donde el Derecho del Trabajo no contempla una recepción explícita en la ley del acoso laboral, pero dicha figura ha venido construyendo por otras fuentes del derecho, especialmente la jurisprudencia y por la doctrina científica. Es el caso de Argentina, Uruguay, España, Chile, Brasil, Venezuela, Suecia, Finlandia o Italia."

54 "La mayoría de los autores concuerdan que los derechos humanos, asegurados en un tratado vigente en Chile, se integran al ordenamiento juridico interno formando parte de la Constitución material y adquiriendo plena vigencia, validez y eficacia jurídica, lo que significa que ningún órgano del Estado puede desconocerlos, debiendo ser respetados, promovidos y protegidos según el mandato de la Constitución".

55 Ver Prado López, Pamela, op. cit. (n. 52) y Gamonal Contreras, Sergio; Prado López, Pamela, op. cit (n. 6).

56 Gamonal y SiERRA expresan "no pareciera ser estrictamente necesario legislar en torno a la materia en estudio, toda vez que nuestra normativa laboral es bastante amplia, $y$, por tanto, las situaciones que configuran el acoso laboral podrían considerarse ya contempladas en las disposiciones vigentes". Agregan que "en el marco de la nueva justicia laboral, los tribunales han resuelto adicionalmente las demandas sobre acoso laboral, dentro del sistema de tutela de derechos fundamentales, acogiendo o rechazando las alegaciones de los trabajadores, en forma que, estimo, es mayoritariamente correcta". Historia de la Ley 20.607, p.117.

57 Entre otros: Corte Suprema, 23 de junio del 2011, ROL 8.798-2010; Sentencia de Juzgado de Letras del Trabajo de Iquique, 26 de agosto de 2011, ROL T- 20-2012.

58 La Corte de Valdivia conociendo de un recurso de protección se pronuncia sobre un caso de acoso laboral, en que una funcionaria que se desempeñaba como paisajista en la Municipalidad de Valdivia la cual es objeto de una persecución persistente que le ha causado detrimento psíquico y moral permanente, desencadenándole un cuadro angustioso, depresivo tipo, reactivo, asociado a conflictos sostenidos en el tiempo en su ámbito laboral. La conducta hostigatoria se atribuía al Director de una unidad de la Municipalidad antes mencionada. El tribunal de alzada, acogió el recurso y ordenó al Funcionario de la Municipalidad de Valdivia, que cesara en su conducta persecutoria poniendo de inmediato término a dicha conducta, trato o medidas abusivas que debiliten o impidan un ambiente laboral sano y digno de los trabajadores de modo que se ponga término a las angustias y aflicciones que se observan en el área de su responsabilidad. Corte de Apelaciones de Valdivia, ROL 665-2006, 6 de septiembre de 2006.
} 
Álvaro Eduardo Domínguez Montoya, Patricio Eleodoro Mella Cabrera, Teodoro Rodolfo Walter Díaz / El acoso en el trabajo: algunos aspectos doctrinarios, jurisprudenciales y legales del acoso moral y sexual en Chile

No obstante lo dicho, este proyecto ingresó al Senado en el año 2008, en el que las disidencias no fueron mayores, más allá de aquellas que planteaban la necesidad de delimitar el alcance de la expresión Acoso Moral, o Acoso Laboral, la extensión de la norma y la amplitud de su interpretación. Finalmente el proyecto logró su propósito en forma de ley luego de casi diez años de tramitación parlamentaria, siendo promulgada el 31 de Julio del 2012 y publicada en el Diario Oficial el 8 de Agosto del 2012 entrando en vigencia desde ese mismo día. En relación a este texto legal y como ha sido una tradición de la Dirección del Trabajo, se ha producido una rápida reacción de este órgano administrativo, $y$ ha procedido a emitir un dictamen que fija el sentido y alcance de las modificaciones introducidas por la ley 20.607 al texto del inciso segundo del artículo $2^{\circ}$, del №1 del artículo 160 y de los incisos $2^{\circ}$ y $6^{\circ}$ del artículo 171 , todos del Código del Trabajo ${ }^{59}$.

Uno de los principales reconocimientos e intervención normativa producida por tal ley fue la modificación del Art. 2 del Código del Trabajo, que tipifica y conceptualiza el acoso moral de la siguiente forma:

"Es contrario a la dignidad de la persona el acoso laboral, entendiéndose por tal toda conducta que constituya agresión u hostigamiento reiterados, ejercida por el empleador o por uno o más trabajadores, en contra de otro u otros trabajadores, por cualquier medio, y que tenga como resultado para el o los afectados su menoscabo, maltrato o humillación, o bien que amenace o perjudique su situación laboral o sus oportunidades en el empleo"60.

\subsubsection{Concepciones configurativas del acoso moral en Chile}

Antes de pasar a analizar con detalle la regulación legal en nuestro ordenamiento jurídico, es necesario detenerse en la concepción y la regulación que se da al acoso moral el cual puede variar dependiendo de cuál es el énfasis de protección y herramientas que se utilicen para la tutela frente a conductas hostigatorias. Así se puede dar la posibilidad que se regule desde el punto de vista civil -en un sentido opuesto al penal- mediante el establecimiento de ilícitos (de actividad o resultado) e infracciones contractuales; desde un punto de vista constitucional a través de la configuración de conductas constitutivas de infracción de derechos fundamentales; desde un punto de vista penal mediante tipificaciones y sanciones; desde el punto de vista de la salud ocupacional, a través del estableciendo de medidas que tengan por objeto prevenir el acoso y entenderlo como un riesgo o bien mediante reconociendo el mismo y sus efectos como enfermedades profesionales, a efecto de otorgar prestaciones de seguridad social. Todas estas regulaciones y por lo mismo concepciones de protección, influyen decisivamente en como entender el acoso laboral en un sistema jurídico debido a los mecanismo y herramientas que se ocupen, el cual determina el nivel de protección que se otorga a las víctimas de los mismos. En nuestro ordenamiento jurídico, estimamos que dos son las principales concepciones reguladoras que se han dado: el acoso moral como una infracción a los derechos fundamentales y el acoso moral como una infracción contractual.

\footnotetext{
59 Dictamen de 09/08/2012, Ord. 3519/034 de la Dirección del Trabajo.

60 En relación a la discusión parlamentaria producida con ocasión de la ley que consagra el acoso en la legislación chilena, se dejó expresa constancia de la complejidad del concepto, indicándose que "las prácticas de acoso laboral o psicoterror, conforman un contorno complejo difícil de describir, pero definiéndolo desde la víctima, éste consiste en el hostigamiento realizado en el ámbito o contexto laboral en el que un sujeto se convierte en blanco del grupo al que pertenece, siendo sometido por éste o por alguno de sus miembros -con la permisividad del resto-, a una persecución que le va a producir importantes trastornos en su salud, tanto física como síquica, siendo necesario en muchos casos la asistencia médica y psicológica". Historia de la Ley $\mathrm{N}^{\circ}$ 20.607 , p. 6
} 


\section{a) Acoso moral como infracción a los derechos fundamentales}

Los estudiosos del derecho del trabajo coinciden en vincular la conducta de acoso laboral al de una hipótesis pluriofensiva de derechos fundamentales ${ }^{61}$. La noción de los derechos fundamentales inespecíficos constituyen "el sustento jurídico conceptual de una política de prevención y sanción de conductas constitutivas de acoso moral laboral en el derecho chileno"62.

Recordemos que en nuestro país existe un vasto e indiscutido reconocimiento a los derechos fundamentales como una limitación al poder del empleador en la ejecución del contrato, entendiendo que el poder que se ejerce sobre la persona del trabajador, es referido solamente a la realización del trabajo y no se puede extender a otros aspectos de la vida del mismo, esto es, el sometimiento económico, jurídico y fáctico no impide la entrada en vigencia ni limita sus derechos fundamentales por integrar su personalidad a una empresa, reforzada esta idea por el efecto horizontal de los derechos fundamentales, cuestión desarrollada por la doctrina laboral y que ha permitido la distinción entre derechos fundamentales específicos e inespecíficos ${ }^{63}$, la cual encontró un campo fértil en la Jurisprudencia Administrativa de la Dirección del Trabajo ${ }^{64}$ y nuestra doctrina nacional ${ }^{65}$.

En clave anterior, los derechos fundamentales inespecíficos son aquellos que posee el trabajador como persona, entendidos como derechos de carácter general estrictamente no laborales de los que es titular todo individuo del grupo social, ejercidos en una relación laboral de la que son parte. Así, "cuando el trabajador cruza la puerta de la fábrica se somete a una ley particular, en cuanto en casa de su patrón le son impuestas normas de comportamiento vinculantes respecto de las cuales no puede negarse a riesgo de incurrir en incumplimientos reprochables y eventualmente sancionables" 66 . Estas normas de comportamiento vinculantes de la relación laboral impuestas por el empleador, se encuentran limitadas por los derechos fundamentales constituyendo un núcleo inalcanzable por el poder de dirección y mando, integrado principalmente por la dignidad, libertad e intimidad del trabajador, que reformulan la relación laboral, racionalizando las facultades del empleador naturales y subyacentes a la relación de trabajo, siendo los derechos fundamentales una fuente enriquecedora y complementaria a esta relación intuitu personae entre los contratantes.

En base a lo indicado surge el concepto de ciudadanía en la empresa que permite desplegar una serie de acciones tendientes a lograr la realización efectiva de los derechos fundamentales del trabajador mientras se produce la prestación de los servicios bajo subordinación y dependencia. Como ya se dijo anteriormente, el proceso se inicia en Chile con la promulgación de la Ley $\mathrm{N}^{\circ}$

\footnotetext{
61 Gamonal Contreras, Sergio; Prado López, Pamela, op.cit. (n. 6), pp. 41-46.

62 Ibid., p. 40.

63 Noción e idea atribuida al concepto de derechos fundamentales inespecíficos desarrollado por la doctrina española; particularmente véase Palomeque, Manuel, Los derechos laborales...(n. 34); Palomeque, Manuel; Álvarez de la Rosa, Manuel. Derecho del trabajo. $-18^{\circ}$ edición-. Madrid, España: Editorial Centro de Estudios Ramón Areces S.A., 1996, pp. 118 ss.

${ }_{64}$ Véanse dictámenes de la Dirección del Trabajo números: 4.842-300, de 15 de septiembre de 1993; 8.273-337, de 9 de diciembre de $1995 ; 287 / 14$, de 11 de enero de 1996; 684/50, de 5 de febrero de $1997 ; 2.309 / 165$ de $1998 ; 4541 / 319$, de 22 de septiembre de $1998 ; 2856 / 162$, de 30 de agosto de 2002; 260/19, de 24 de enero de $2002 ; 2.328 / 130$, de 19 de julio de 2002 ; 3.276/173, de 16 de octubre de 2002; 2875-72 de 22 de julio de 2003; $\mathrm{N}^{\circ} 0543 / 31$ de 2 de febrero de 2004; $1133 / 36$, de 21 de marzo de 2005; 1279/019, de 17 de marzo de 2006; No 221/035, de 5 de junio de 2009, y 4731/081, de 3 de octubre de 2010.

65 Particularmente en Chile Véase Gamonal Contreras, Sergio. Ciudadanía en la empresa o los derechos fundamentales inespecificos. Montevideo, Uruguay: Fondo de Cultura Universitaria, 2004.

${ }_{66}$ Baylos Grau, Antonio. "En torno al Estatuto de los Trabajadores: la prohibición de inquirir sobre la ideología, creencias y vida privada del trabajador". En: Lecciones del derecho del trabajo en homenaje a los profesores Bayón Chacón y del Peso y Calvo. Madrid, España: Facultad de Derecho de la Universidad Complutense, 1980, p. 307.
} 
Álvaro Eduardo Domínguez Montoya, Patricio Eleodoro Mella Cabrera, Teodoro Rodolfo Walter Díaz / El acoso en el trabajo: algunos aspectos doctrinarios, jurisprudenciales y legales del acoso moral y sexual en Chile

19.759, de 2001, que recibe el impacto reformador en varios preceptos del Código del Trabajo, destacadamente sus artículos 2 y 5 , en cuanto el primero alude a la prohibición de discriminación y el segundo en cuanto indica perentoriamente que las facultades del empresario no pueden acarrear como resultado la afectación de los derechos constitucionales del trabajador.

En tal esquema, y al ser el fundamento mismo del constructo de acoso laboral la tutela de los derechos fundamentales inespecíficos, cuando el trabajador se vea afectado por conductas de acoso su canal idóneo ante los tribunales de justicia debe realizarse a través del procedimiento de tutela laboral regulado en el art. 485 y ss. Código del Trabajo, respecto del cual se harán algunos comentarios más adelante ${ }^{67}$.

En específico, sobre los derechos fundamentales potencialmente afectados por las conductas hostigadoras, concordamos con la doctrina indicando que pueden ser: el derecho a la integridad física y psíquica, el derecho a la vida privada y a la honra, a la inviolabilidad de toda forma de comunicación privada y a la no discriminación, encontrando el núcleo central en la dignidad de la persona ${ }^{68}$.

\section{b) El acoso moral como hipótesis de incumplimiento contractual}

El contrato de trabajo genera un entramado de derechos y obligaciones para el empresario y el trabajador, enunciando como aquellas fundamentales la de prestar los servicios personales y pagar una remuneración por tales servicios, agregándose a ellas un catálogo dentro de los cuales debemos mencionar la ocupación efectiva, la capacitación ocupacional, la obligación de seguridad, etc. ${ }^{69}$. De esta forma y al igual que lo que ocurre en el caso del acoso como constitutiva de derechos constitucionales, variadas pueden ser las obligaciones del contrato que eventualmente pueden tipificar la conducta de acoso laboral definida en el precepto 2 del Código del Trabajo tantas veces citado. Examinemos las que se estiman relevantes:

\section{c) La obligación de ocupación efectiva}

Se describe este derecho como la facultad del trabajador para realizar efectivamente los servicios para los cuales fue contratado por el empresario y en consecuencia éste se encuentra obligado a proporcionar dicho trabajo convenido ${ }^{70}$. Se trata así que el empleador no puede bajo el pretexto de mantener la remuneración, dejar al trabajador en una inactividad más o menos prolongada, ya que esa situación es intolerable tanto del punto vista contractual como de la dignidad del trabajador. Naturalmente que una de las conductas hostigatorias puede ser precisamente el colocar al trabajador en una situación de pasividad laboral, mediante una variada gama de conductas, entre las cuales se puede citar una de aquellas que menciona LyMANN. En la hipótesis anterior el empre-

\footnotetext{
67 Sobre este punto Planet Sepúlveda, Lucía, op. cit. (n. 52), p. 114.

68 "La lesión de la dignidad de la persona no se va a presentar en abstracto, sino a partir de la delimitación de los concretos derechos fundamentales y libertades públicas en sentido estricto que, incluidos dentro de este concepto, como la integridad física y moral, el honor, la libertad de comunicación, la igualdad, se ven tan directa e intensamente violados por las distintas modalidades de acoso. En última instancia, el acoso atenta a la dignidad de la persona”. Rojas Rivero, Gloria. Delimitación, Prevención y Tutela del Acoso Laboral. Madrid, España: Editorial Bomarzo, 2005, p.16.

69 Lizama Portal, Luis. Derecho del Trabajo. Santiago, Chile: Lexis Nexis 2005, pp. 66 y ss.

70 Para Barbagelata, el empleador debe "Proporcionar al trabajador, ocupación efectiva en la calidad y cantidad que corresponda en cada situación, cuando la no realización de tareas del cargo, afecte su buen nombre, su prestigio dentro o fuera del establecimiento, perjudique la cualificación o impida adquirirla o superarla, y en toda otra situación que afecte sus derechos sindicales, o la dañe moral o patrimonialmente". Barbagelata, Héctor-Hugo. Derecho del Trabajo. Tomo I. Montevideo, Uruguay: Fundación de Cultura Universitaria, 2007, p. 191.
} 
sario está incumpliendo una obligación contractual y por ende surge el derecho para el trabajador para obtener el cumplimiento efectivo de su derecho ${ }^{71}$, e incluso obstar por el autodespido o despido indirecto consagrado en el art. 171 del Código del Trabajo, amparado en la causal del 160 No 7 del mismo cuerpo legal ${ }^{72}$. El Máximo Tribunal de nuestro país, también ha recogido el carácter obligacional de la ocupación efectiva ${ }^{73}$ que debe dar el empresario al trabajador.

\section{d) La obligación de capacitación}

Atendida las exigencias de la competitividad, y el incesante progreso tecnológico -que obliga al trabajador a desarrollar una habilidad de adaptación a dichos cambios- ha surgido en esta última década la necesidad de dotar y asegurar al trabajador las competencias indispensables para que la prestación de servicios sea la requerida por la organización empresarial. En este aspecto se ha afincado la existencia de un contenido contractual moderno que otorga el derecho a la capacitación en favor del trabajador ${ }^{74}$.

El contenido de este derecho obliga al empleador a proporcionar, dentro de sus límites económicos y técnicos, los conocimientos, técnicas e instrumentos necesarios para desarrollar sus tareas al interior de la empresa a fin de evitar la obsolescencia de este. En este contexto, se han planteado casos en que el trabajador reclama que es objeto de exigencias profesionales por las cuales no se le capacita, y luego se le formulan reproches sobre su trabajo de forma descalificadora o con expresiones groseras o intimidantes. En otras ocasiones se le discrimina en la asignación de jornadas de capacitación, lo que le impide lograr ascensos o el reconocimiento profesional de sus pares. Las hipótesis anteriores pueden implicar la infracción a la obligación de capacitación y por ende el trabajador puede accionar de estas conductas hostigatorias desde la perspectiva de las acciones que concede el contrato de trabajo. Como por ejemplo configurar un autodespido fundado en los preceptos 160 No 7 en relación al 171, ambos del Código del Trabajo.

\section{e) La obligación de seguridad}

El autor español SALA Franco, sostiene que la obligación empresarial de protección al trabajador en materia de seguridad y salud laboral venía configurada como una obligación contractual e integrada en el contenido básico del contrato de trabajo ${ }^{75}$. A su vez PALOMEQUE LóPEz ${ }^{76}$ señala que la protección de la seguridad y salud de los trabajadores mediante la prevención de los riesgos laborales se articula en base a dos conceptos: 1.- La definición de una política de prevención de riesgos laborales a realizar por la Administración Pública, y 2.- El reconocimiento de un derecho del derecho del trabajador a una protección "eficaz" en orden a garantizar su seguridad y su salud

\footnotetext{
7 En una sentencia del año 2010, se estableció como causal de incumplimiento el no haber otorgado el trabajo convenido a la demandante, y no haber adoptado las medidas pertinentes para que cese la conducta hostigatoria (a la actora la dejaron sentada en su mesa de trabajo sin asignarle labor alguna). $2^{\circ}$ Juzgado del Trabajo de Santiago, RIT No 'T-38-2009, 11 de enero de 2010.

72 En este sentido la doctrina chilena ha dicho que el trabajador tiene derecho a "exigir a su empleador que le proporcione los elementos necesarios para la prestación de los servicios y le impone una prohibición al empleador de dejarlo inactivo, salvo que exista caso fortuito o fuerza mayor u otra causa eximente de responsabilidad". GAMONAL, Sergio; Guidi, Caterina. Fundamentos de Derecho Laboral. Santiago, Chile: Editorial Lexis Nexis, 2008, p. 54.

73 Corte Suprema, ROL 4125-04, 30 de Noviembre de 2005.

74 La formación profesional no solo constituye un deber del Estado, sino además "una obligación del empleador que se despliega junto al resto del haz emergente de la relación individual de trabajo". BARRETro GHIONE, Hugo. La obligación de formar a cargo del empleador. Montevideo, Uruguay, 2003, pp. 88 y ss.

75 Sala Franco, Tomás. Derecho de la prevención de riesgos laborales. Valencia, España: Tirant Lo Blanch, 2004, p. 71.

76 Palomeque, Manuel; Álvarez de la Rosa, Manuel, Derecho... (n. 63), pp. 643-654.
} 
Álvaro Eduardo Domínguez Montoya, Patricio Eleodoro Mella Cabrera, Teodoro Rodolfo Walter Díaz / El acoso en el trabajo: algunos aspectos doctrinarios, jurisprudenciales y legales del acoso moral y sexual en Chile

en todos los aspectos relacionados con el trabajo, mediante la adopción de cuantas medidas sean necesarias.

En nuestro país existe consenso en la doctrina ${ }^{77}$ que la obligación de seguridad está referida al derecho del trabajador a exigir que el empleador adopte todas las medidas necesarias para proteger eficazmente su vida y salud en el lugar de trabajo, y tiene una naturaleza contractual. Para Palavecino, en virtud del contrato el empleador asumirá la obligación legal de tomar todas las medidas necesarias para proteger eficazmente la vida y salud de los trabajadores (art. 184, inc.1 del Código del Trabajo). De esta obligación general del empleador es posible derivar la obligación específica de mantener un ambiente libre de acoso psíquico en los lugares de trabajo ${ }^{78}$. Lo anterior dada la intensidad de la protección que consagra el art. 184 del Código del Trabajo, al disponer que el empleador estará obligado a tomar todas las medidas necesarias para proteger eficazmente la vida y salud de los trabajadores, manteniendo las condiciones adecuadas de higiene y seguridad en las faenas. Esta obligación de protección de la vida del trabajador está estrechamente conectada al derecho fundamental contemplado en el artículo 19 No 1 de la Carta Fundamental.

Pues bien, durante la ejecución del vínculo laboral, la existencia de conductas hostigadoras pueden afectar la salud física y mental del trabajador, y dicha afectación puede incidir directamente en instrucciones $u$ órdenes que pueden poner materialmente en peligro al trabajador (como por ejemplo que se ordene un trabajo en altura con implementos inseguros), o simplemente ser la consecuencia de una serie de actos que finalmente repercuten en su salud, constituyendo esta última vertiente la hipótesis más recurrente de la afectación del derecho. A modo ejemplar existen numerosos pronunciamientos judiciales que concluyen la existencia de enfermedades de naturaleza mental como consecuencia de la conducta hostigatoria ${ }^{79}$.

Por lo anterior y reiterando lo ya dicho, por virtud de la aplicación del artículo 184 del Código del Trabajo, debiera obligatoriamente exigirse dentro del reglamento interno un procedimiento que, respetando en la esencia la noción de debido proceso, fijara normas para encausar e investigar las denuncias e hipótesis de acoso moral dentro de la empresa, ya que precisamente es la actual organización del trabajo la que constituye un factor determinante en la generación de espacios que facilitan el ejercicio de violencia de un particular sobre otro, debiendo por mandato legal el empleador prevenir dichas situaciones o al menos diseñar los canales internos para el encause, investigación, resguardo y sanción frente al hostigamiento moral, más aún cuando existe un reconocimiento científico de "la nueva plaga laboral del siglo XXI" ${ }^{80}$ que hace del todo previsible la ocurrencia de situaciones de tal naturaleza en el seno de las relaciones de trabajo.

\subsection{LAS FUENTES NORMATIVAS}

Aun cuando el acoso laboral puede estar normado por variadas fuentes del Derecho del Trabajo, atendida a nuestra tradición estimamos útil señalar la regulación del acoso en las fuentes escritas, comenzando con la norma de jerarquía mayor, la Constitución, luego la Ley, después el Reglamento Interno y otras. Todo ello sin descartar la normativa de origen internacional contenida en los tratados de Derechos Humanos o la actividad de la OIT que incide en esta materia. Lo anterior,

7 Lizama Portal, Luis, op.cit. (n. 69), pp. 67 y 68

78 Palavecino Cáceres, Claudio, "La protección contra... (n. 48).

79 Sobre el tema puede verse causa T 20-2014, Juzgado de Letras del Trabajo de Temuco.

80 Piñuel y Zabala, Iñaki. Mobbing, Cómo sobrevivir... (n. 22). p 50. 
en virtud del mandato contenido en el art. 459 No 5 del Código del Trabajo, en cuanto consagra el principio de la horizontalidad de las fuentes ${ }^{81}$.

\section{a) La Constitución}

Cuando una conducta de acoso moral se ejecuta, lo primero en ser vulnerado es la dignidad del trabajador agredido. Afectando así, la primera y primordial garantía constitucional establecida en el art. $1^{\circ}$ de la carta fundamental, "los hombres nacen libres e iguales en dignidad y derechos". Si bien la dignidad no se encuentra dentro del catálogo de las garantías protegidas y tratadas en el art. 19 de la Carta Fundamental, ella impregna todos los derechos fundamentales ${ }^{82}$. En tal contexto, la dignidad en opinión de la doctrina constitucionalista constituye el núcleo básico de los derechos constitucionales, sin embargo no se ha desarrollado su contenido, cuestión que la jurisprudencia constitucional debe realizar a fin de orientar la aplicación e interpretación de esta garantía ${ }^{83}$. Particular importancia tiene en el caso del Código del Trabajo ya que la dignidad aparece mencionada destacadamente en el precepto 2 de la codificación laboral, al igual que en el artículo 154 № 13 , a propósito del Reglamento Interno. La omisión de precisar su contenido es igualmente replicada en la jurisprudencia del trabajo, postulándose entonces la necesidad de ir dotándola de contenido desde la óptica del derecho del trabajo a este fundamental derecho, lo que es perfectamente posible a través de las sentencias que se dicten en los procedimientos de tutela laboral ${ }^{84}$.

Además, la variedad de conductas y medios que pueden ser utilizados por el sujeto activo para lograr el efecto hostigador, dará lugar a que se afecten una o más de las garantías reconocidas en el aludido artículo 19 de la Constitución, de manera que a través de las acciones u omisiones que emplee el sujeto activo de la conducta acosadora, podrá resultar vulnerada la garantía del numeral $1^{\circ}$ "el derecho a la vida y a la integridad física y psíquica de la persona"; el No 2 "igualdad ante la ley", o el $n^{\circ} 4$ "el respeto y protección a la vida privada y a la honra de la persona y su familia". En este sentido MANGARELLI señala que la utilización de cámaras de video en lugares de trabajo sin justificación suficiente y en forma desproporcionada podría quedar comprendida en

81 Sobre esta materia es útil tener presente que en virtud de la reforma al procedimiento laboral contenida en la Ley $\mathrm{N}^{\circ}$ 20.087 del año 2006, se reformó el requisito de las sentencias laborales, estableciéndose que el juez podrá utilizar variadas fuentes sin indicar orden de prevalencia, ello explica la expresión "horizontalidad de las fuentes". Mella Cabrera, Patricio; Domínguez Montoya, Álvaro. "Conflicto de derechos constitucionales y juicio de tutela laboral en Chile: Estado doctrinal, legal y jurisprudencial", en: Revista de Derecho, ${ }^{\circ} \mathrm{XXXIX}$, vol. 2, pp. 32 y ss. Valparaíso, Chile: Escuela de Derecho, Pontificia Universidad Católica de Valparaíso, 2012.

82 El máximo tribunal ha señalado que el ordenamiento jurídico representa una adecuada ecuación entre los valores que deben respetarse con miras a la dignidad humana y la exigencia del bien común. Corte Suprema, 28 Enero de 1986, Revista Gaceta Jurídica $\mathrm{N}^{\circ} 69$, p. $34, \mathrm{~N}^{\circ} 67 / 71,1986$.

83 "El artículo $1^{\circ}$ inc. $1^{\circ}$ de la Constitución Política de la República de Chile, umbral del Capítulo I, dedicado a las Bases de la Institucionalidad, proclama que: Las personas nacen libres e iguales en dignidad y derechos, principio matriz del sistema institucional vigente del cual se infiere, con claridad inequívoca, que todo ser humano, sin distinción ni exclusión, está dotado de esa cualidad, fuente de los derechos fundamentales que se aseguran en su artículo 19. De la dignidad se deriva un cúmulo de atributos, con los que nace y que conserva durante toda su vida. Entre tales atributos se hallan los derechos públicos subjetivos o facultades que el ordenamiento jurídico le asegura con carácter de inalienable, imprescriptible e inviolables en todo momento, lugar y circunstancia." Tribunal Constitucional, Rol №1287, 8 de septiembre de 2009.

84 En una sentencia se estableció que la investigación e interrogatorios realizados por la empresa con ocasión de una pérdida de mercaderías ocurrida el 21 de mayo de 2010, y que se imputó a dos trabajadoras, se vulneró el derecho a la honra, que asegura la Constitución. Señalándose que la honra es sinónimo de derecho al respeto y protección del buen nombre de una persona, derecho de carácter personalísimo, que es expresión de la dignidad humana consagrada en el artículo $1^{\circ}$, que se vincula también con el derecho a la integridad psíquica de la persona. $2^{\circ}$ Juzgado del Trabajo de Santiago, RIT No T-220-2010, de 27 de octubre de 2010. 
Álvaro Eduardo Domínguez Montoya, Patricio Eleodoro Mella Cabrera, Teodoro Rodolfo Walter Díaz / El acoso en el trabajo: algunos aspectos doctrinarios, jurisprudenciales y legales del acoso moral y sexual en Chile

una situación de violencia o acoso moral en el trabajo ${ }^{85}$, No5 “la libertad de conciencia, la manifestación de todas las creencias y el ejercicio libre de todos los cultos que no se opongan a la moral, a las buenas costumbres o al orden público" (ejemplo el caso de la musulmana), N6 "la libertad de conciencia", No 16 "La libertad de trabajo y su protección", №19 "el derecho de sindicarse en los casos y forma que señale la ley" ${ }^{\prime 86}$. Destacadamente esta conducta puede afectar la prohibición de discriminación contenida en los art. 19 ํ16 en relación al art. 19 №2 de la Carta Política ${ }^{87}$.

\section{b) La Ley}

Antes de la promulgación de la Ley $\mathrm{N}^{\circ} 20.607$, las conductas de acoso eran estudiadas desde la perspectiva del perjuicio a la salud del trabajador y en consecuencia, como infracción a la obligación de seguridad que se impone al empleador por el art. 184 del Código Laboral ${ }^{88}$, sin perjuicio que el acto hostigatorio pudiere impactar en el cumplimiento de otras obligaciones del contrato, como por ejemplo no otorgar el trabajo convenido o postergar el derecho a capacitación, si es que ello se estima también una obligación contractual ${ }^{89}$.

Desde esta perspectiva contractual la cual se desarrolla ampliamente en la codificación laboral parece lógico que la regulación propuesta por la Ley $\mathrm{N}^{\circ} 20.607$ debe considerar el orden de las materias que norma el Código del Trabajo y ello dio por resultado que la proscripción de la conducta de acoso laboral abarcó tres aspectos del Código del Trabajo, los cuales corresponden a los siguientes:

a) La definición de Acoso Laboral: en este apartado, el legislador estimó procedente fijar el contenido del término acoso moral en el artículo $2^{\circ}$ del Código del Trabajo, precepto que tiene alcances precontractuales, en cuanto norma también el proceso de selección de personal, esto es, antes de que se formalice el contrato de trabajo. La decisión de incluir la definición en el precepto 2 no es irrelevante, ya que dicho precepto está ubicado en el título preliminar del código, destacándose una vocación de amplitud en su aplicación. En cambio, si se hubiera incluido en la norma de terminación, ello habría originado probablemente una aplicación restrictiva del concepto.

b) En relación a la Terminación del Contrato de Trabajo: se genera una nueva hipótesis de causal de término del vínculo laboral, agregándose una letra f) en el art. $160 \mathrm{n}^{\circ} 1$ del Código, es decir, un nuevo caso de conducta indebida grave. En este escenario, la causal otorga al empleador la facultad de poner fin al contrato de trabajo cuando un trabajador sea quién incurre en conductas de acoso laboral en contra de otro, sin derecho a indemnización alguna. Como ya se dijo anteriormente si el acoso laboral proviene de un tercero, este no sería imputable al empleador, sin

85 Mangarelli, Cristina. "Protección de la vida privada del trabajador en el lugar de trabajo" en: Octavo Congreso Regional Americano del Derecho del Trabajo y de la Seguridad Social. Bogotá, Colombia: Colegio de Abogados del Trabajo, 2010 , p. 127.

85 Estas conclusiones se pueden validar fácilmente al contrastar los derechos constitucionales citados con el listado de conductas postuladas por HeINZ LEYMANN citadas anteriormente en este trabajo.

87 Así por ejemplo, se ha acogió una denuncia por violación de derechos constitucionales en contra de una empresa, fundada en que se vulneró el derecho a la no discriminación por raza de una secretaria perteneciente a la etnia mapuche. $2^{\circ} \mathrm{Juzgado}$ de Letras del Trabajo de Santiago, RIT T- 403- 2010, 19 marzo 2011.

88 Gamonal Contreras, Sergio; Prado López, Pamela, El mobbing... (n. 6), pp. 100-103.

89 Para alguna doctrina el contrato de trabajo genera el derecho del trabajador a la capacitación ocupacional, cuyo contenido es que el operario participe del proceso destinado a promover, facilitar, fomentar y desarrollar sus aptitudes, habilidades o grados de conocimientos, con el fin de permitirle mejores oportunidades y condiciones de vida y trabajo. Lizama PorTal, Luis, op.cit. (n. 69), p. 68 . 
perjuicio de que ese hostigamiento pueda calificarse como incumplimiento de alguna de las obligaciones citadas precedentemente e imputables al empresario.

c) Se reforma el Autodespido: en este punto se debe recordar que el precepto 171 del Código del Trabajo permite la terminación del contrato de trabajo por iniciativa del trabajador, en el evento que sea el propio empleador el que incurra en alguna de las causales que señala la norma aludida (esto es alguna de las conductas indebidas graves señaladas en el art. $160 \mathrm{n}^{\circ} 1$, o actos, omisiones o imprudencias temerarias indicadas en el $160 \mathrm{n}^{\circ} 5$ y finalmente, el incumplimiento grave de las obligaciones que impone el contrato, aludida en el $170 \mathrm{n}^{\circ} 7$ ).

Además, el inciso $2^{\circ}$ del artículo 171 del Código del Trabajo, señala que "el trabajador afectado podrá reclamar del empleador, simultáneamente con el ejercicio de la acción que concede el inciso anterior, las otras indemnizaciones a que tenga derecho", contemplando, por tanto la posibilidad importante de ejercer las correspondientes acciones de indemnización por daño moral. Esta postura se ve reforzada por la redacción del art. 495 No 3 del Código del Trabajo en cuanto permite que el trabajador víctima de una violación de sus derechos constitucionales por parte del empresario pueda solicitar que se condene al agresor a pagar "las indemnizaciones que procedan", las cuales no pueden ser otras que la reparación de los perjuicios dado que el contrato de trabajo sigue vigente y por ende no hay posibilidad de ordenar el pago de indemnizaciones por término de contrato.

d) Por otra parte, se estimó correcto hacer modificaciones a los estatutos de los funcionarios públicos, en atención a regular esta misma materia dentro de aquellas relaciones de trabajo, la cual por factores de extensión no será abordada en este trabajo.

e) Reglamento Interno: en el contexto de estudio, esta fuente es de particular importancia para normar los distintos procedimientos que una empresa debe implementar para garantizar un trato digno a sus trabajadores ${ }^{90}$. Sin perjuicio de que en ocasiones, es la ley la que impone la obligación de incluir un procedimiento de reclamación y resolución en determinadas materias, ello no descarta la necesidad de que dicho reglamento los contenga. Así el art. $154 \mathrm{~N}^{\circ} 11$ del CT impone un procedimiento para conocer de las sanciones que se aplicarán a los trabajadores por infracción a esta fuente. En el mismo sentido el $N^{\circ} 12$ del mismo precepto señala que el reglamento debe contener un procedimiento al cual se someterán las medidas de resguardo y sanciones en caso de denuncia por acoso sexual. Finalmente por obra de la modificación introducida por la Ley $\mathrm{N}^{\circ}$ 20.348 de 19 de junio de 2009 , esta fuente reglamentaria debe incluir un procedimiento respecto de los reclamos que se deduzcan por infracción a la prohibición de discriminación salarial o principio de igualdad de remuneraciones entre hombres y mujeres que se sanciona en el art. 62 bis del Código del trabajo, el cual fue también introducido por la última ley citada.

Como se advierte la Ley No 20.607 no impuso una obligación de incluir un procedimiento en el reglamento interno para conocer de los casos de reclamo por acoso moral en el trabajo, sin embargo ello es aconsejable dado que la conducta de acoso laboral impacta en varios derechos constitucionales de los cuales son titulares los trabajadores y por ende, se debe recordar que el empleador está obligado a cautelar el respeto y ejercicio de los mismos de conformidad a lo prevenido en el art. $5^{\circ}$ del Código del Trabajo. Por otra parte, la redacción del inciso tercero del artículo

\footnotetext{
90 En cuanto a esta fuente, se ha sostenido que "El carácter unilateral de las normas es aún más nítido en cuanto a la elaboración del reglamento interno de la empresa. El poder normativo del director de empresa fue criticado por una aparte de la doctrina que vio en él una anomalía jurídica, mientras que otros concluyen que se trata de la consagración de la teoría institucional de la empresa que pretenden. Algunos sindicatos anhelan la desaparición de este reglamento". JAVILlier, Jean-Claude. Derecho del Trabajo. Montevideo, Uruguay: Fundación de Cultura Universitaria, 2007, p. 153.
} 
171, menciona que si el empleador no hubiere observado el procedimiento establecido en el título IV, libro II, responderá en la forma señalada en los incisos primero y segundo precedente, lo que sugiere la conveniencia de incluir un procedimiento para tratar las denuncias por acoso laboral en el reglamento interno.

En tal sentido estimamos que por virtud de la aplicación del artículo 184 del Código del Trabajo, debiera obligatoriamente exigirse dentro del Reglamento Interno un procedimiento que, respetando en la esencia la noción de debido proceso, fijara normas para encausar e investigar las denuncias e hipótesis de acoso moral dentro de la empresa, ya que precisamente es la actual organización del trabajo la que constituye un factor determinante en la generación de espacios que facilitan el ejercicio de violencia de un particular sobre otro, debiendo por mandato legal el empleador prevenir dichas situaciones o al menos diseñar los canales internos para el encause, investigación, resguardo y sanción frente al hostigamiento moral, más aún cuando existe un reconocimiento científico y jurídico de "la nueva plaga laboral del siglo XXI"91 que hace del todo previsible la ocurrencia de situaciones de tal naturaleza.

\subsection{ElEMENTOS, CARACTERÍSTICAS Y CLASES DEL ACOSO MORAL EN BASE A LA REGULACióN NORMATIVA CHILENA}

Teniendo en cuenta lo ya analizado, el acoso se puede estructurar en base a los siguientes criterios: a) trato humillante y vejatorio; b) la habitualidad o reiteración; c) el animus desestabilizador; d) gravedad de la conducta ${ }^{92}$, lo cual en cierta medida fija los puntos o nudos centrales de la figura en comento.

Desde este punto de vista, el acoso laboral presenta rasgos distintivos en nuestro ordenamiento jurídico, los cuales diferenciaremos para estructurar de mejor forma y así analizar algunos puntos que estimamos de mayor relevancia al momento de trazar la confluencia entre la concepción jurídica y la concepción psicológica del acoso moral en nuestro ordenamiento jurídico:

\subsubsection{El acoso moral se produce dentro de una relación de trabajo}

Si bien las conductas de hostigamiento en variados aspectos de la vida social no son privativas de la relación laboral, en el caso que nos convoca, jurídicamente lo que interesa para efectos es sólo aquello que ocurre en el ámbito de una prestación de servicios subordinada y por cuenta ajena.

Dicho requerimiento "se trata de un aspecto consustancial a la propia naturaleza del acoso dada la situación de subordinación jurídica o de hecho en que debe encontrar la persona objeto de esa conducta". No obstante, debe matizarse lo anterior, ya que no todos los factores, conductas y comportamientos deben tomarse en consideración exclusiva de la ocasión o en el lugar del trabajo, así, "no cabría excluir de entrada la calificación de acoso moral por el hecho de que algunos de las circunstancias probadas hubieran tenido lugar extramuros del lugar trabajo, siempre y cuando las mismas pudieran ponerse en relación con otros hechos propios del contexto laboral"93. En efecto, "aún cuando lo habitual y típico es que las conductas se produzcan durante la jornada laboral y en el centro de trabajo, nada impide que alguna de las manifestaciones de estas conductas se realice fuera de ese ámbito o momento"94.

\footnotetext{
91 Piñuel y Zabala, Iñaki, Mobbing. Cómo sobrevivir... (n. 26), p 50.

92 Sagardoy Bengoechea, Juan. op. cit. (n. 44), pp. 98 y ss.

93 Jurado Segovia, Ángel, op. cit. (n. 23), p. 132.

94 Urrutikoet xea Barrutia, Mikel, op. cit. (n. 3), pp. 143 y ss.
} 
Sobre el punto y si bien nos pronunciaremos más adelante, se puede presentar un problema sobre este criterio caracterizador, en el sentido en que se desdibuja la línea de contornos y extensión de la figura del acoso moral en aquellas hipótesis de acosos laboral en un contexto de tercerización laboral. En efecto una interpretación restringida, podría llevar a que se rechace dicha hipótesis analizando tal criterio desde un punto de vista contractual y geográfico. En tal sentido creemos que tal caracterización debe entenderse más allá del modelo clásico, considerando las cada vez más modernas y complejas organizaciones empresariales, más aún cuando pueden convivir en un mismo centro de trabajo diversas empresas relacionadas mediante vínculos tercerización laboral.

\section{a) Estructura de hostigamiento laboral y los sujetos intervinientes}

Es claro que el acoso laboral puede darse en las diversas dimensiones que surgen en una relación laboral, "el sicoterror laboral, se da en una proliferación jerárquicamente diversa, es decir, al incorporarse nuevos trabajadores capaces de amenazar la promoción profesional de un superior, o a la inversa al tener esta actitud y prácticas alguien que se incorpora a la empresa acosando a su directivo o directivos para ocupar su puesto"95.

Así las cosas, podemos distinguir distintas clases de acoso laboral ${ }^{96}$, las cuales derivan del concepto, particularmente atendiendo a los sujetos activos y pasivos del acoso.

a) Jerárquico o descendente, también conocido como bossing: el agresor es un superior jerárquico del trabajador afectado. Esto constituye la hipótesis usual de hostigamiento en la relación laboral. En este esquema no se debe descartar la posibilidad que el sujeto activo "la ocupe una pluralidad de personas"97.

b) Ascendente: la víctima es acosada por sus subalternos. Esta modalidad, poco común, puede darse cuando una persona se incorpora a una empresa y sus dependientes no aceptan su metodología de trabajo; o cuando una persona es promovida y sus antiguos colegas no reconocen su nueva jerarquía. Naturalmente se debe descartar al empresario que como se dijo, es una posibilidad muy remota dada la facultad de despido que posee este, y particularmente, por la redacción del artículo 2 del Código del Trabajo.

c) Horizontal o entre pares: se da entre trabajadores que tienen el mismo nivel jerárquico, y puede obedecer a múltiples razones como celos profesionales, envidia, sentimientos de inferioridad del autor de las conductas, etc. ${ }^{98}$

En relación a la clasificación anterior, no existe mayor discrepancia aun cuando se pueden sugerir otras. Sobre esto, GAMONAL distingue entre acoso moral horizontal, vertical y mixto ${ }^{99}{ }^{100}$.

\footnotetext{
95 Historia de la Ley No 20.607 , p. 7.

96 Sobre el punto ver: Sagardoy Bengoechea, Juan, op. cit. (n. 44) p.100-101; Gamonal Contreras, Sergio; Prado López, Pamela, El mobbing... (n. 6), p. 23; Planet Sepúlveda, Lucía, op. cit. (n. 52), p. 98.

97 Jurado Segovia, Ángel, op. cit. (n. 23), p. 135. En el mismo sentido Urrutikoetxea Barrutia, Mikel, op. cit. (n. 3), pp. 146.

98 Romanik Foncea, Katy, op. cit. (n. 28), p. 11.

99 Gamonal y Prado en esta materia, clasifican el acoso moral, distinguiendo uno horizontal, vertical y mixto, siendo particularmente novedoso el concepto de esta última categoría, el cual corresponde a aquel que "comienza como un acoso horizontal, pero en que luego la jefatura o empleadores toman conocimiento y no adoptan ninguna medida para que la situación se solucione", al decir que "hay una verdadera complicidad entre los agresores, trabajadores de similar posición del acosado y del jefe o empleador. Puede ocurrir, también, a la inversa, en el sentido de que el acoso comience como vertical descendente y luego se unan al victimario uno o más trabajadores de similar jerarquía que la víctima" Gamonal Contreras, Sergio; Prado López, Pamela, El mobbing... (n. 6), pp. 23-25.

100 Se ha dicho que "en este supuesto, el acoso comienza como horizontal, vale decir, el agresor es uno o varios de los compañeros de trabajo de la víctima, pero en un momento posterior, toma conocimiento de la situación la jefatura o el empleador y, en vez
} 
Álvaro Eduardo Domínguez Montoya, Patricio Eleodoro Mella Cabrera, Teodoro Rodolfo Walter Díaz / El acoso en el trabajo: algunos aspectos doctrinarios, jurisprudenciales y legales del acoso moral y sexual en Chile

Según estas apreciaciones, la doctrina citada y el mismo concepto legal de nuestro ordenamiento jurídico sugieren que, el sujeto activo puede estar comprendido no sólo el empleador o la persona en la cual delega su poder de dirección (entiéndase, gerentes, administradores, jefes de área, supervisores) sino también otro u otros trabajadores, dado que no hay inconveniente en que esta conducta reprochable se desplegada por un colectivo de personas (un grupo de compañeros de trabajo que expresa o tácitamente deciden hostigar a un compañero de trabajo). En esta última hipótesis no se descarta que el victimario sea una persona de inferior jerarquía a la del acosado o acosada.

Esta característica excluye la posibilidad que el acoso provenga de un sujeto externo a la relación laboral, en cuyo caso la conducta lesiva pudiere obtener una protección a través de la obligación de seguridad que tiene el empresario respecto del trabajador, en atención a que el hostigamiento efectuado por un tercero pueda afectar la integridad psíquica y física del trabajador, situación en la cual el empleador deberá adoptar las medidas tendientes a evitar los efectos del hostigamiento o del acoso en el trabajador, que naturalmente deberá reclamar de ello. Pudiendo llegar incluso a configurarse una causal de autodespido a favor del trabajador.

En relación al sujeto pasivo, la hipótesis habitual es un acoso entre un superior jerárquico hacia un trabajador, o entre trabajadores, e incluso de parte de un trabajador hacia un superior jerárquico. Sobre este punto, la Dirección del Trabajo ${ }^{101}$ ha señalado que el sujeto pasivo puede ser "uno o más trabajadores, siempre que de la agresión u hostigamientos reiterados, ejercidos en su contra, resulten las consecuencias previstas en el citado precepto".

Ahora, no obstante lo dicho, existe una actual caracterización que engloba de mejor forma dichas distinciones: acoso empresarial; acoso entre trabajadores; personas ajenas a la propia organización empresarial, distinguiendo en la última opción entre clientes y empresas relacionadas ${ }^{102}$.

\section{b) La reiteración o sistematicidad de la conducta hostigatoria}

Sobre el punto existe uniformidad en la doctrina respecto de la sistematicidad de la agresión u hostigamiento, en el sentido que debe ser reiterado en el tiempo, siendo del todo consustancial y necesario a tal instituto ${ }^{103}$. La definición legal de acoso contemplada en el artículo 2 del Código del Trabajo, impone como requisito que la conducta sea reiterada, sin indicar el lapso de ella, lo que puede esclarecerse con la doctrina.

Sobre el punto es necesario tener en cuenta que dicho criterio -en estricto de temporalidaddebe ser analizado de manera flexible, ya que "un solo incidente intenso, o una situación de acoso de muy breve duración puede tener un impacto definitivo, sobre todo si logra destruir la confianza del acosado en su competencia o interferir en su sentido de compromiso con su actividad"104.

de intervenir en favor de la víctima, no adoptan ninguna medida para solucionar la situación. En estos casos existe claramente una omisión negligente por parte del empleador, sin perjuicio de que puedan presentarse también situaciones de hostigamiento directo por su parte. Por lo tanto, se configura una situación de complicidad entre todos los agresores. No obstante, es posible a su vez que el acoso laboral mixto tenga lugar a la inversa, esto es, que comience como un tipo de mobbing vertical descendente, para ver sumado luego el comportamiento hostil de uno o más trabajadores de similar jerarquía de la víctima”.

101 Dirección del Trabajo, Ord. No 3519/034, de 9 de agosto de 2012.

102 Urrutikoetxea Barrutia, Mikel, op. cit. (n. 3), pp. 201 y ss.

103 Ibid., pp. 93 y ss.

104 Escudero Moratalla, Jf.; Poyatos, I.; Matas, G. Mobbing: análisis multidisciplinar y estrategia legal; adaptado a la ley 26/2003, de 30 de diciembre. Comentarios y formularios. Barcelona, España: Boch, 2004, p. 59. 
En este contexto, siguiendo a LEYMANN, se señalan que la conducta debe realizarse dentro de un período de 6 meses que determina muchas veces y a su vez que la reiteración de la conducta deba darse dentro de ese lapso. No concordamos con tal estandarización de tiempo. Bastan limitados actos perturbadores, frecuentes y duraderos en el tiempo, que debido a su intensidad y gravedad, pueden evidenciar una situación de $\operatorname{acoso}^{105}$, dándose naturalmente en un lapso inferior a 6 meses, por lo que la repetición de las acciones u omisiones hostigadoras, serán determinadas por juez quien evaluara la extensión de la reiteración, lo que naturalmente depende de la naturaleza de los actos acosadores, siendo un elemento importante el grado de cercanía del acosador y la víctima. En otras palabras, se deberá estar al caso concreto para determinar el tiempo que debe abarcar la conducta hostigatoria ${ }^{106}$, no obstante que se ha constatado una cierta rigidez en la interpretación de que debe entenderse por reiteración y hostigamiento por los tribunales de justicia. ${ }^{107}$

Finalmente, creemos opinable, desde un plano técnico-jurídico, exigir o intentar incorporar algún requisito o exigencia de índole cuantitativo, como un número mínimo de agresiones o un plazo, para entender que estamos ante un conducta reiterada.

Por otro lado, respecto de la conducta en sí, el texto legal es omnicomprensivo de acciones y omisiones, ya que el Código en el artículo $2^{\circ}$ utiliza la expresión "toda conducta", comprendiendo faltas de actuación.

Respecto del medio empleado para lograr el objetivo del sujeto activo el legislador no ha dejado duda que cualquier medio que tenga la idoneidad suficiente puede ser instrumento de acoso, por lo que de esta manera habrá que determinar en el caso concreto si el medio o forma empleada es idónea para lograr el objetivo de hostigar a la víctima ${ }^{108}$. Puede tratarse de expresio-

105 Sobre este aspecto cabe destacar que la jurisprudencia se ha pronunciado respecto de la frecuencia del hostigamiento, al resolver que "en ninguna norma se establece el número de días que debe hostigarse a un trabajador para que se configure el acoso laboral y en el caso en concreto, éste se extendió por 11 días en el mes de abril y a lo menos otros dos meses entre la fecha que volvió de su última licencia el 24 de agosto de 2009 hasta la fecha de la presentación judicial en octubre del mismo año, por lo que medió un tiempo prudente para afectar sicológicamente a la trabajadora". Corte de Apelaciones de San Miguel, Rol No 65-2010, 3 de junio de 2010 .

106 En este sentido una sentencia de la Corte de Apelaciones de Talca, cuyos hechos consisten en que una trabajadora al momento de indicarle a su empleadora que se encuentra en estado de embarazo comienza a sufrir una serie de conductas que califica de hostigatorias (como por ejemplo no facilitar las llaves de los servicios higiénicos, no dejar la llave de acceso al sistema computacional, por lo cual la trabajadora debía llamar a Santiago para solicitar nuevamente la clave, y además ser objeto de comentarios ofensivos ). El Tribunal estima que dichos hechos no eran de una duración continua ni reiterada, debido a las constantes licencias médicas de la trabajadora, a lo que se une el escaso aporte probatorio por la parte recurrente, se concluye el rechazo a la demanda interpuesta, posteriormente la Corte de Apelaciones de Talca rechazó el recurso de nulidad posterior, y entre sus argumentos señaló que la conducta de mobbing debe constituir una agresión u hostigamiento efectivo y reiterado, y no comprendería la circunstancia de disparidad de criterios entre empleador y trabajador, los conflictos o discrepancias que pueden ocurrir en una relación laboral, no constituyen por si solo una manifestación de acoso laboral. Sentencia Corte de Apelaciones de Talca, Rol 228-2010, 10 de Diciembre de 2010.

107 CaAmaño y Ugarte, constatan tal realidad, indicando que "en la práctica jurisprudencial se aprecia la extraordinaria importancia que se le da a este componente y el efecto que genera es, con frecuencia, negativo, pues se condiciona la noción de acoso y las demandas son rechazadas por no demostrarse la reiteración de la agresión u hostigamiento. La consecuencia de que los tribunales eleven este elemento a la calidad de "esencial" es clara: al no configurarse la persistencia temporal de la agresión, el análisis de la lesión de los derechos fundamentales del trabajador, que es el verdaderamente relevante y que constituye el núcleo del acoso laboral, termina siendo minimizado o, peor aún, simplemente soslayado". CAAmaño Rojo, Eduardo; UGarTe CATAldo, José Luis. "El acoso laboral: tutela y prueba de la lesión de los derechos fundamentales", en: Revista Ius et Praxis, Vol. 20, ${ }^{\circ} 1$, p. 83. Talca, Chile: Facultad de Derecho, Universidad de Talca, 2014.

108 En un caso, se resolvió, que la actora fue objeto de hostigamientos sistemáticos y continuados, que trajo consecuencias negativas para la salud de la trabajadora. Dichos comportamientos hacia ella emanaban del supervisor xx y "combinaban la simpatía con el engaño, el humor con la amenaza, el silencio con gritos y garabatos, ofensas y desprestigio que terminaron enfermándola ocasionándole un cuadro depresivo". Juzgado del Trabajo Concepción, RIT No O-681-2010, 4 de abril de 2010. 
Álvaro Eduardo Domínguez Montoya, Patricio Eleodoro Mella Cabrera, Teodoro Rodolfo Walter Díaz / El acoso en el trabajo: algunos aspectos doctrinarios, jurisprudenciales y legales del acoso moral y sexual en Chile

nes verbales, medios escritos (carta, correo electrónico), uso de lenguaje soez y ordinario, agresiones físicas, gestos, comentarios de carácter sexual, etc. Naturalmente que estas conductas pueden constituir hipótesis autónomas de infracción al contrato de trabajo, o incluso satisfacer alguna hipótesis delictivas (lesiones, injuria, abuso sexual).

c) La intencionalidad en la conducta

IÑAKi PIÑUeL, expresa que el acoso laboral:

"Tiene como objetivo intimidar, apocar, reducir, aplanar, amedrentar, y consumir emocional e intelectualmente a la víctima, con vistas a eliminarla de la organización o satisfacer la necesidad insaciable de agredir, controlar y destruir que suele presentar el hostigador, que aprovecha la situación que le brinda la situación organizativa particular (reorganización, reducción de costes, burocratización, cambios vertiginosos, etc.) para canalizar una serie de impulsos y tendencias sicopáticas"109.

De esta forma el sujeto activo del acoso moral se caracteriza por ejecutar los actos de hostigamiento dirigidos por los sentimientos negativos de celos o envidia, en razón de los bienes materiales de la víctima o "por las cualidades positivas de la misma, como puede ser su inteligencia, brillantez personal, ecuanimidad, destrezas específicas en relación a alguna profesión u oficio"110. Como se advierte, el autor citado alude a la existencia de una conducta deliberada o intencional, lo que sugiere la concurrencia de un elemento subjetivo que los redactores de este trabajo descartan, lo que coincide con la opinión de la doctrina sobre la materia. ${ }^{111}$.

En este punto es necesario recalcar que la intencionalidad de la conducta hostigatoria no surge como una característica de este ilícito. En efecto, "desde una perspectiva jurídica, lo cierto es que se tiende mayoritariamente a una objetivización de las conductas de acoso" ${ }^{\text {"112 }}$, en otros términos, "la intensionalidad se <objetiviza> haciéndola derivar de elementos objetivos y no así de un análisis psicologista de la conducta del acosador". Es más, en los modelos legislativos comparados se observa que "los elementos de mala fe y de intención de dañar no se ha tomado en consideración en tales definiciones normativas, incluyéndose, asimismo, en el tipo legal la conducta de acoso involuntaria o incluso inconsciente. Lo que el legislador ha tenido en cuenta son las consecuencias para la víctima"113.

En nuestra configuración normativa no aparece desprenderse algún elemento de carácter subjetivo como dolo o culpa que configure la hipótesis de acoso, es más, esta revela una configuración objetiva ligado a una afectación, menoscabo, maltrato o humillación, amenaza o perjuicio que se mide en el sujeto pasivo y no en el activo del acoso. Es más, son factores reveladores de dicha intencionalidad la estructura misma del acoso: el conflicto y las represalias; el trato diferenciado y unidireccional de la conducta acosadora; comportamientos contrarios a la buena fe, a la

\footnotetext{
109 Piñuel y Zabala, Iñaki, Mobbing: cómo sobrevivir... (n. 26), p.55

110 Historia de la Ley $\mathrm{N}^{\circ} 20.607$, p. 6.

111 Sobre este punto, CAAmaño señala que el acoso laboral requiere de la concurrencia de ciertos elementos, entre los que cita la "Premeditación o no, con lo cual se introduce un elemento subjetivo como el dolo, lo que resulta criticable frente a comportamientos lesivos de derechos fundamentales, pues podría tornarse difícil la prueba de la intención del agresor", CaAMAÑo, Eduardo. "La noción... (n. 46), pp. 215-240.

112 Serrano Olivares, Raquel. El Acoso Moral en el Trabajo. Madrid, España: CES, 2005, pp. 36 y ss.

113 Ibid., p. 41.
} 
legalidad; el abuso de derecho y posición dominante; sistematicidad y duración de la conducta; los efectos nocivos en la salud y alteraciones psicológicas.

Este punto es de vital importancia, ya que la incorporación de un elemento subjetivo en la figura legal que se sanciona, hace muy difícil su prueba y desvanece el carácter protector de esta legislación en materia de hostigamiento laboral, poniendo al trabajar en una posición del todo gravosa en un escenario en el que no contribuyo a su materialización.

\section{d) Perjuicio en la víctima}

Otra característica del acoso laboral tiene que ver con sus consecuencias en la persona del acosado. En la mayoría de los casos, y debido a la magnitud y extensión temporal del hostigamiento, la víctima desarrolla cuadros depresivos y baja autoestima ${ }^{114}$. Se trata entonces de un daño objetivo, que debe ser demostrado por la víctima, so pena de descartar el acoso. El resultado lesivo puede ser variado, en el sentido que puede afectar las condiciones laborales del trabajador, sean de naturaleza pecuniaria o ambientales, o bien pueden referirse a la persona del trabajador, produciendo trastornos o enfermedades de orden psicológico e incluso psiquiátrico.

En el ámbito laboral el perjuicio se hace evidente en variados aspectos de la relación de trabajo. Así, la víctima puede ser objeto de tratos discriminatorios en relación a reajustes o aumento de remuneraciones, otorgamiento de bonos de desempeño, o en relación a ascensos, condiciones ambientales en que se desarrolla el trabajo, a excluirlo de actividades de capacitación y recreación. La conducta que se reprocha debe afectar la relación laboral, tanto en su ejecución como en la terminación. Lo normal será que el acoso es invocado durante la vigencia del contrato, y precisamente es el objetivo más importante que se busca lograr al regular esta materia. La situación de terminación contractual, como efecto del acoso puede resolverse a través de las normas sobre terminación del contrato de trabajo. Interesante cuestión sugiere la expresión "oportunidad en el empleo", por lo que pudiera entenderse que el acoso laboral puede ocurrir incluso en la zona precontractual del contrato, lo cual descartamos según los argumentos expresados en su oportunidad. Un entendimiento limitado de la misma expresión puede atarse a las posibilidades de ascenso o mejor remuneración de un trabajador.

Una cuestión interesante sobre este punto son las observaciones realizadas en cuanto la exigibilidad de un daño efectivo a la salud. Indica la doctrina que:

"Este resultado no es un elemento del tipo jurídico. Puede haber acoso moral sin daño a la salud, aunque naturalmente siempre habrá daño moral. En términos jurídicos éste no puede confundirse con aquél, aunque ambos puedan concurrir. No compartimos, pues, la línea doctrinal y sobre todo, judicial, que entiende necesaria la producción de unos daños a la salud psíquica de la o el trabajador acosado para que podamos hablar de mobbing. Esta posición nos parece que no se corresponde con el carácter de riesgo laboral que desde su origen se atribuye al mobbing"115.

\footnotetext{
114 Se señala en la historia de la ley que "las consecuencias en el ámbito personal del trabajador siempre son nefastas, pues la alta probabilidad de que se desarrolle una patología hace que sea un tema de enorme trascendencia en el ámbito laboral, pues por la vía del acoso laboral la persona paulatinamente comienza con ofuscación y frustración pasando luego éstos a constituirse en cuadros depresivos de diversa índole, llegando éstos a fraguar la actitud de que el trabajador deba inexorablemente tomar la resolución de tener que irse de su puesto de trabajo" Historia de la Ley No 20.607, p. 7.

"15 Informe del Observatorio Vasco sobre Acoso Moral en el trabajo. El acoso moral "mobbing" en los lugares de trabajo: comprender para intervenir. En http://mobbingopinion.bpweb.net/artman/publish/printer_1291.shtml.
} 
Álvaro Eduardo Domínguez Montoya, Patricio Eleodoro Mella Cabrera, Teodoro Rodolfo Walter Díaz / El acoso en el trabajo: algunos aspectos doctrinarios, jurisprudenciales y legales del acoso moral y sexual en Chile

En la misma línea se ha dicho que "el concepto psicológico o psiquiátrico de acoso moral se construye en torno a la producción del daño psicológico, sus causas y consecuencias. En cambio, desde el punto de vista jurídico, la conducta de hostigamiento psicológico es reprochable per se, en la medida en que supone un atentado contra la integridad moral y la dignidad del trabajador"116, en efecto no parece pertinente desde el punto jurídico por obvias razones "ya que pudieran quedar impunes en otro caso conductas lesivas de los derechos fundamentales sin menoscabar necesariamente la salud de la victima"117.

\subsection{La tutela judicial del Acoso Moral en Chile}

La existencia de un núcleo de derechos que ampare al trabajador en la relación de trabajo subordinado, requiere adicionalmente, una tutela judicial efectiva ${ }^{118}$, y ello implica la existencia de mecanismos procesales idóneos para el ejercicio de las acciones que hagan realidad el disfrute de dichos derechos. En esta perspectiva, no basta la garantía procesal contemplada en el artículo 19 No 3 de la Carta Fundamental, en cuanto al derecho -en este caso del trabajador- a ser juzgado en un procedimiento racional y justo, descartando la posibilidad de ser juzgado por comisiones especiales. De esta forma, de existir una conducta de acoso laboral, el trabajador debe disponer de acciones eficaces tendientes a impedir que dicha conducta se mantenga, se sancione al autor de la conducta hostigatoria y se logre reparar o indemnizar los perjuicios que se causen a consecuencia del ilícito laboral e infracción contractual según ya se comentó. Los mecanismos que se estimen disponibles corresponden a los siguientes:

\subsubsection{El Acoso Laboral y el procedimiento de Tutela de Derechos Fundamentales ${ }^{119}$}

Atendido que la conducta de acoso laboral constituye una lesión a derechos fundamentales del trabajador, una opción de tutela procesal es la utilización del procedimiento de tutela de derechos fundamentales, contemplado en los arts. 485 y ss. del Código del Trabajo.

Este procedimiento presenta algunas ventajas para la víctima de acoso, las cuales pueden sintetizarse entre las más relevantes: a) La preferencia de tramitación contemplada en el artículo 488 del Código del Trabajo; b) La indemnización adicional no inferior a seis ni superior a once remuneraciones mensuales señalada en el precepto 489 ; c) La reincorporación del trabajador en el caso del despido discriminatorio grave, autorizado en el mismo precepto; d) La facultad del juez de ordenar, en la primera resolución, la suspensión de los efectos del acto impugnado, cons-

\footnotetext{
116 Serrano Olivares, Raquel, op. cit. (n. 112), p. 27.

117 Urrutikoetxea Barrutia, Mikel, op. cit. (n. 3), p. 91.

118 Para Palomeque y Álvarez, "Los trabajadores tienen derecho, asimismo, a obtener la tutelas efectiva de los jueces y tribunales en el ejercicio de sus derechos e intereses legítimos, sin que, en ningún caso, pueda producirse indefensión". Palomeque, Manuel; Álvarez de la Rosa, Manuel, op. cit. (n. 63), p.139.

119 Los profesores FerRada y WALTER consideran que el proceso de tutela de derechos fundamentales fue creado para hacer efectiva la protección especializada de los derechos fundamentales de los trabajadores, ante una percepción de debilidad del mecanismo general, pero sin que exista posteriormente un amparo general contra la actuación judicial. Se presenta como el mecanismo principal de protección de los derechos fundamentales, dejando el Recurso de Protección como una alternativa residual, bastante inoperante por lo demás, si es que tiene en cuenta el breve plazo establecido para su interposición como así también la carencia de elementos que reconozcan la disparidad ante un escenario procesal. Ferrada BórQuez, Juan Carlos; WALTER Díaz, Rodolfo. "La tutela laboral de derechos fundamentales en el código del trabajo o la aplicación del derecho como Arte de Magia" (A propósito de la sentencia de la Excma. Corte Suprema "Monsalve con Muellaje STI S.A"), en: Revista de Derecho, año LXXVIII, pp. 91-11. Concepción, Santiago: Facultad de Derecho, Universidad de Concepción, 2010.
} 
tituyendo ésta una resolución de carácter cautelar, y que se consagra en la regla 492; e) El alivio probatorio en favor del denunciante indicado en el precepto $493 \mathrm{y}$; f) la posibilidad de obtener la reparación de los daños morales, según la interpretación de la norma 495, No 3 del Código del Trabajo, al expresar "incluidas las indemnizaciones que procedan".

En tal caso, la acción de tutela tendrá por objeto obtener el cese de la conducta hostigatoria en la hipótesis que la relación laboral este vigente, y si ella es ocultada bajo la excusa de un despido justificado, el trabajador afectado podrá reclamar del despido con ocasión de la vulneración de derechos fundamentales autorizado en el art. 489 del Código del Trabajo, pudiendo solicitar las indemnizaciones típicas y una adicional que puede fijarse en el rango de 6 a 11 remuneraciones mensuales o dependiendo del derecho infringido la reincorporación ${ }^{120}$.

En esta línea, otra cuestión que creemos relevante apuntar es lo relativo a la hipótesis referida a la compatibilidad entre el ejercicio de la acción por despido indirecto contemplada en el artículo 171 del Código del Trabajo y el procedimiento de tutela. Estimamos que el trabajador también podrá verse beneficiado de dichas formas procesales, por cuanto el canal idóneo de sustanciación de dichos intereses y derechos debe materializarse mediante un procedimiento destinado a la infracción de derechos fundamentales, por cuanto la esencia justificadora del constructo de acoso laboral recae precisamente en la vigencia de los derechos fundamentales inespecíficos del trabajador.

Sobre el punto debemos señalar que la actual tendencia jurisprudencial entiende incompatible la acción de autodespido con el procedimiento de tutela ${ }^{121}$, indicándose que la acción prevista por el inciso $1^{\circ}$ del artículo 489 del Código del Trabajo, no procede cuando ha sido el trabajador quien ha puesto término a la relación laboral por la vía del despido indirecto contenida en el artículo 171 del precisado cuerpo normativo, puesto que el artículo 489 inciso primero del Código del Trabajo, consagra la acción de tutela por vulneración de derechos fundamentales cuando "se hubiere producido con ocasión del despido", tratándose por consiguiente de aquella situación en que el empleador toma la decisión de desvincular al trabajador, con vulneración de los derechos fundamentales protegidos, lo que igualmente se desprende cuando el legislado habla que la acción exclusivamente al "trabajador afectado", debiendo entenderse que ha sido afectado por un despido atentatorio de derechos fundamentales". De igual forma apoya dicha interpretación que el reconocimiento del derecho que tiene todo trabajador de denunciar la vulneración de los derechos fundamentales protegidos, a través de la acción contemplada en el artículo 485 del Código del Trabajo, que permite su ejercicio durante la vigencia de la relación laboral", agregando que "de este modo, la ley ha dotado al trabajador de una acción de tutela que precisamente -ejercida durante la vigencia de la relación laboral- tiene por objeto impedir que el dependiente deba soportar vul-

120 La trabajadora afirma que fue víctima de conductas que enmarcan dentro de lo que hemos indicado como acoso laboral (cambio de funciones, del lugar de trabajo y un menoscabo económico de la trabajadora, y que se efectuaron de manera unilateral, carencia de un espacio físico para cumplir con sus labores y falta de documentación, todo ello derivo en un aislamiento a la trabajadora y en un cuadro depresivo). En el juicio aludido se acreditó que la trabajadora sufrió una lesión a sus derechos fundamentales producto del acoso laboral efectuado por el empleador, y que en definitiva sus pretensiones fueron acogidas por el tribunal, por lo que debió ser reincorporada la trabajadora a su función original, indemnizada por daño moral, recibir disculpas públicas y tratamiento por el estrés ocasionado. Este fallo fue objeto de un recurso de nulidad el que no prosperó. Juzgado de Letras del Trabajo de Puente Alto, RIT No T-01-2009, 10 de marzo de 2010.

121 Por todos ver: Corte Suprema, 18 de enero de 2013, ROL 2202-2012 y Corte Suprema, 28 de agosto de 2013, ROL 3689-2013. Respecto a la compatibilidad de dichas acciones ver Sierra Herrero, Alfredo. "Acción de tutela laboral y despido indirecto. Comentario a la sentencia "Gómez Cattini con Camilo Ferrón Chile S.A." Segundo Juzgado de Letras del Trabajo de Santiago, 3 diciembre de 2009, RIT T-11-2009, en: Revista de Derecho, Vol. 17, $\mathrm{n}^{\circ}$ 2. Coquimbo, Chile: Facultad de Derecho, Universidad Católica del Norte. 
Álvaro Eduardo Domínguez Montoya, Patricio Eleodoro Mella Cabrera, Teodoro Rodolfo Walter Díaz / El acoso en el trabajo: algunos aspectos doctrinarios, jurisprudenciales y legales del acoso moral y sexual en Chile

neraciones de tal envergadura que lo lleven a audespedirse, sin lograr la protección efectiva de sus derechos".

No concordamos con dicha posición, optando por la corriente jurisprudencial que acoge dicha tesis, por lo cual pasaremos a señalar sus principales argumentos:

1) La primera cuestión es de índole gramatical y más precisamente de orden semántico, teniendo que ver con el significado de la locución "con ocasión", que no es otro que el de aquello que se realiza en un momento dado o en la oportunidad de algo o con motivo de alguna cosa o por causa de ella; es decir "con ocasión del despido" significa lingüísticamente que en la oportunidad o con motivo del término de la relación laboral. Cuando esa extinción consiste en una renuncia unilateralmente producida por el dependiente, la expresión "con ocasión" reenvía a todo aquello que se presenta como circunstancia de ese acto $y$, entonces, hace imposible discernir entre el antes y el después de la extinción del vínculo. Lo anterior es más evidentemente, cuando se observa que un trabajador explicita su decisión de poner fin a una relación laboral está procediendo, obviamente, al interior de un contrato vigente que de otra manera no podría entenderse a qué pretendiera poner término.

2) El segundo fundamento es de índole normativo. Es efectivo que el artículo 489 habla de la vulneración de derechos fundamentales a que se refieren los dos primeros incisos del artículo 485, a lo que no puede darse otro alcance que la concreta referencia a los derechos fundamentales que, precisamente, están mencionados en esos dos incisos. Ahora bien, esos derechos fundamentales son amparados por el artículo 485, interpretado globalmente y no sólo en la referencia a que acaba de aludirse. La norma contempla expresamente, en su inciso tercero, que los derechos y garantías de sus capítulos anteriores han de entenderse lesionados cando el ejercicio de las facultades que la ley reconoce al empleador limita su pleno desarrollo, en forma arbitraria o irrespetuosa de su contenido esencial; ninguna prescindencia es aquí posible; mal que mal, a la postre es ésta la piedra angular del sistema tutelar propuesto en el Párrafo $6^{\circ}$ del Título I del Libro V del código.

3) Creemos oportuno también referirnos a lo indicado por UGARTE ${ }^{122}$, quien al tratar sobre el despido indirecto y la tutela, concluye que el despido indirecto es una modalidad de despido, al tener los mismos efectos, y que el artículo 489 del Código del Trabajo, cuando habla de la lesión de derechos fundamentales con ocasión del despido, no cierra en ningún caso la posibilidad de accionar de tutela frente a un autodespido, sino solamente para determinar quién está dotado de la legitimación activa. Y añade que el término con "ocasión", busca determinar el momento en que se ha producido la lesión, al terminar la relación laboral, y no un tipo de lesión específico. De no entenderlo así nos llevaría a un absurdo difícil de entender, si empleador lesiona derechos fundamentales y no despide, y lo hace el trabajador recibe una sanción menor, propia de un despido injustificado.

Finalmente indica que en caso de dudas, el artículo 489 debe ser interpretado de conformidad al principio pro-homine, que obliga a preferir el sentido interpretativo más amplio y de mayor alcance a las normas legales que tutelan los derechos fundamentales.

Respecto de este controversial punto, se debe tener presente que recientemente, en sentencia Rol $N^{\circ} 4.299-2014$ de 18 de diciembre de 2014, librada en recurso de unificación de ju-

122 Ugarte Cataldo, José Luis. Tutela de derechos fundamentales del trabajador. Santiago, Chile: LegalPublishing, 2010 , p. 94. 
risprudencia, el Máximo Tribunal acogió la tesis de que el despido indirecto es una modalidad del despido, cuestión que naturalmente puede influir en una futura acogida de la compatibilidad procesal entre la acción de tutela laboral y el autodespido.

Otra cuestión en que creemos conveniente reparar es lo relativo al plazo de caducidad para las acciones ventiladas con ocasión del acoso laboral mediante las formas del procedimiento de tutela, ya que el exiguo plazo contemplado para dicha acción podría resultar en cierta medida incompatible con la naturaleza misma del acoso laboral, ya que el artículo 486 del Código del Trabajo indica que "deberá interponerse dentro de sesenta días contados desde que se produzca la vulneración de derechos fundamentales alegada" y precisamente una de las características del hostigamiento laboral es que este se trata de un acto reiterado y repetitivo en el tiempo, conformado además por un conjunto de acciones y omisiones que no pueden ponderarse de manera aislada.

Sobre el punto "es evidente que el plazo previsto por la ley debe contarse desde el momento en que la conducta lesiva concluyó, atendiendo que se trata de una lesión continuada de los derechos considerados básico por la sociedad. No está de más señalar que sobre los jueces en esta materia pesa la obligación prevista en la propia Constitución, que obliga a todos los órganos del Estado -artículo 5०- a "proteger" y "promover" los derechos esenciales de las personas"123.

A lo anterior se debe agregar, como reiteradamente lo hemos dicho en el curso de este trabajo, que el acoso laboral no está constituido por un solo hecho sino que por el contrario está dado por un conjunto de actos de hostigamiento, prácticas, circunstancias y conductas lesivas de derechos fundamentales hacia el trabajador por parte del empleador o de quién lo representa ejerciendo las facultades de mando y dirección, por lo que la naturaleza del acoso laboral exige necesariamente la ocurrencia de un conjunto de actos de hostigamiento, por lo que mal podría entenderse que existe una fecha clara de inicio, sino que más bien la conducta lesiva de derechos fundamentales, constitutiva de acoso y los efectos tiene repercusiones esta la fecha actual, lo cual evidentemente vienen dado por una pluralidad de acciones en que la suma de ellas y no cada una individualmente considerada, constituye la hipótesis de acoso, por lo mismo estamos frente un ilícito continuado cuyo reproche se mantiene en el tiempo, no solamente por el análisis en abstracto de la conducta, sino que en concreto, ya que el hecho y su principal conducta configurativa por regla general se mantiene ${ }^{124}$.

\subsubsection{El acoso laboral y el procedimiento de aplicación general}

Si bien el hostigamiento constitutivo de acoso laboral implica necesariamente la lesión a alguno de los derechos fundamentales del trabajador, lo lógico e idóneo es que el mecanismo procesal para su tutela inhibitoria y resarcitoria sea la acción de tutela de derechos fundamentales mediante las formas establecidas para el procedimiento de tutela de derecho fundamentales -no obstante las observaciones indicadas respecto del autodespido-, lo cual no impide que la víctima opte por las acciones típicas que se contemplan en el Código del Trabajo y que en consecuencia no sea necesario invocar el procedimiento de tutela laboral, sin mencionar obviamente la poco utilidad práctica que conlleva tal opción.

Dicha hipótesis si bien no es aconsejable por no desplegar la.virtualidad protectora de la acción de tutela, puede ser útil en la medida que se invoque frente un despido injustificado -en su amplia expresión- o bien como forma procesal para tramitar una acción de auto despido si

123 Ibid., p. 25.

124 En este sentido Sentencia Juzgado de Letras de Osorno, 3 de junio de 2010, RIT T-5-2010. 
Álvaro Eduardo Domínguez Montoya, Patricio Eleodoro Mella Cabrera, Teodoro Rodolfo Walter Díaz / El acoso en el trabajo: algunos aspectos doctrinarios, jurisprudenciales y legales del acoso moral y sexual en Chile

como consecuencia del acoso laboral se produce un incumplimiento o infracción contractual ${ }^{125}$ contemplado en el artículo 171 en relación al 160 No 7 del Código del Trabajo ${ }^{126}$. La ventaja que puede exhibir esta elección, es que se puede reclamar la indemnización de los daños morales, sin el riesgo de que el juez estime que no es posible acumularlos a las indemnizaciones típicas con la indemnización tarifada del procedimiento tutela, no obstante que creemos que tales indemnizaciones son acumulables, puesto que la naturaleza de la misma difieren: una busca resarcir los perjuicios morales y la otra busaca sancionar una conducta lesiva de garantías constitucionales, constituyendo una hipótesis de indemnización punitiva.

En tal esquema, es oportuno señalar las alternativas que se presentan:

\section{a) El caso del despido}

En esta hipótesis, aun cuando el trabajador estime que el despido que invoca el empleador tiene como antecedente conductas de hostigamiento pero que por problemas probatorios no es posible acreditar, bien puede reclamar del despido ilegal o injustificado sin acudir a la tutela laboral ${ }^{127}$ o bien acudir de manera principal a la misma y ejercer subsidiariamente la acción de despido injustificado en su más amplio término. Esta postura puede explicarse por una insuficiencia probatoria respecto de la lesión del derecho constitucional, insuficiencia que no concurre respecto de la prueba del cumplimiento por parte del trabajador de la conducta invocada para poner término a su contrato por parte de su empleador, haciendo más viable el reclamo judicial conforme al art. 168 del Código del Trabajo, pudiendo demandar además una acción resarcitoria de perjuicio morales ${ }^{128}$.

En tal escenario creemos que lo mejor es optar por un ejercicio conjunto, pero subsidiario de acciones.

\section{b) En relación al autodespido}

Esta vía puede descartar la duda interpretativa acerca de la imposibilidad de unir el despido indirecto a la acción de tutela laboral, y dado el principio de especialidad que rige la tutela, forzoso sería utilizar al procedimiento de aplicación general ${ }^{129}$.

\footnotetext{
125 En sentencia se declara que la empleadora incurre en la causal de término del contrato contemplada en el artículo $160 \mathrm{~N}^{\circ} 7$ del Código del Trabajo esto es incumplimiento grave de las obligaciones impuestas en el contrato. Juzgado del Trabajo de Arica, RIT No T-7-2010, 28 de mayo de 2010.

126 Uno de los primeros fallos que detectamos que fundamentan un autodespido por incumplimiento grave de las obligaciones laborales por afectar derechos como la integridad síquica y física. Sentencia Corte de Apelaciones de Santiago, 04 de julio 1989 , Revista Gaceta Jurídica, año XVI, 1989, N 109, p. 86.

127 En relación a un despido, el tribunal resuelve "Que en este mismo orden de ideas lo que en opinión de la Corte se puede inferir, en primer término, que las situaciones de reproche de la empleadora carecían de asidero, por ejemplos, los atrasos imputados se encuentran autorizados, el ingreso de computador personal del actor, fue para cumplir con las labores encomendadas, y en segundo lugar, que se puede concluir que la empleadora no estaba a gusto con los servicios aportados por el actor". Corte de Apelaciones de Santiago, Rol No 858-2010, 25 de enero de 2011.

128 Ver sobre el punto Gamonal Contreras, Sergio. El daño moral en el contrato de trabajo -2 $2^{\circ}$ ed.-. Santiago, Chile: Legal Publishing, 2007; Gamonal Contreras, Sergio. "Evolución del daño moral por término del contrato de trabajo en el derecho chileno", en: Revista de Derecho, n. 39, pp. 161-176. Valparaíso, Chile: Escuela de Derecho, Pontificia Universidad Católica de Valparaíso, 2012. Existe un fallo reciente que reconoce dicha hipótesis en materia laboral: Corte Suprema, 7 de noviembre de 2014, ROL 2746-2014.

129 En la sentencia señalada en el número anterior, el tribunal acoge el despido indirecto propuesto en forma subsidiaria, señalando que no es procedente alegar el despido indirecto en una tutela laboral. Los hechos constitutivos de acoso correspondían a presiones para aceptar rebajas de sueldo, privarlo de acceso a algunos lugares y al libro de asistencia, amenazas directas, eliminación de bonos, gratificaciones, etc. Corte de Apelaciones de Santiago, Rol No 858-2010, de 25 de enero de 2011.
} 
La situación que justifica esta vía se encuentra en que no es admisible obligar al trabajador continuar con el vínculo laboral si es objeto de un trato humillante, constitutivo de acoso, pudiendo entonces poner término al contrato fundado en la causal $160 \mathrm{~N}^{\circ} 1$ letra f) del Código del Trabajo, siempre y cuando ello sea obra del empleador ${ }^{130}$. Si se tratara de un acoso horizontal o ascendente, la terminación solo podría ajustarse a la causal de incumplimiento grave que regula el $160 \mathrm{~N}^{\circ} 7$ del Código del Trabajo, argumentando la violación de la obligación de seguridad y salud que pesa sobre el empleador. La distinción es importante, ya que solo en el primer caso se podría reclamar el daño moral de acuerdo a la redacción del inciso segundo del 171 del Código del Trabajo.

\subsubsection{El recurso de protección}

De acuerdo al principio de primacía constitucional, nada impide que la víctima de acoso laboral enderece un recurso de protección tendiente a obtener que cese el hostigamiento laboral ${ }^{131}$. Lo anterior es perfectamente posible dado que las conductas de acoso bien pueden privar perturbar o amenazar algunas de las garantías constitucionales protegidas por la acción constitucional y que nominativamente se citan en el artículo 20 de la constitución. La acción de protección no es subsidiaria y por ello puede intentarse, pero se debe recordar que de hacer efectiva esta vía, el artículo 485 del Código del Trabajo veda la posibilidad de intentar el procedimiento de tutela laboral.

En todo caso es útil tener presente que este medio resulta inoperante para la protección y eficacia de los derechos constitucionales del trabajador al interior de la empresa, por el temor a las represalias por parte del empleador, el cual, eventualmente podría reaccionar despidiendo al empleado que acciona de protección. Esta circunstancia llevó al legislador a introducir el juicio de tutela laboral ${ }^{132}$.

Si bien este mecanismo ha sido utilizada principalmente para cautelar hipótesis de acoso en el ámbito de las relaciones laborales reguladas principalmente por el derecho administrativo, actualmente debe descartarse, ya que expresamente luego de un debate jurisprudencial ${ }^{133}$, ha uniformado la jurisprudencia en el sentido de hacer compatible la tutela de derechos fundamentales respecto de los funcionarios públicos ${ }^{134}$.

\subsection{El perjuicio causado por el Acoso Moral y su reparación}

Sin ninguna duda la utilidad de regular el acoso laboral se proyecta en los mecanismos y técnica de reparación que el derecho laboral debe proporcionar a la víctima de acoso laboral, la que será

\footnotetext{
130 En sentencia del Juzgado del trabajo de Puente Alto, el tribunal rechaza un autodespido fundado en que a raiz de un reclamo interpuesto por la trabajadora ante la Inspección del Trabajo- lo que fue aceptado por el empleador- se inicia con posterioridad un hostigamiento consistente en conductas humillantes, discriminación, violencia sicológica, hostigamientos injustos y desproporcionados por parte de un superior. La acción es rechazada por falta de prueba. Juzgado del Trabajo de Puente Alto, RIT No T-5-2009, de 26 de marzo de 2010.

131 En este sentido, causa Corte de Apelaciones de Valdivia, Rol No 665-2006, 6 de septiembre de 2006, en que acogió la protección fundada en la existencia de conductas de hostigamiento. Al contrario, en fallo de Corte de Apelaciones de Antofagasta, Rol 4102011, 31 de agosto de 2011, se rechaza la protección impetrada por una funcionaria municipal por falta de prueba, la cual alega haber sido objeto de acoso laboral. De igual forma Corte de Apelaciones de Concepción, Rol N¹642-2011, 23 de enero de 2012.

132 Mella Cabrera, Patricio; Domínguez Montoya, Álvaro, op. cit. (n. 81), pp. 188 y 189.

133 Por todos ver Corte Suprema, sentencia de 5 de Octubre de 2011, Rol N 1971-2011.

134 Entre algunos nuevos pronunciamientos ver Corte Suprema, fallo de 30 de Abril de 2014, Rol No 10.972-2013; Corte Suprema, fallo de 21 de octubre de 2013, ROL 3515-2014.
} 
distinta según si el acoso se produce durante la ejecución del contrato o durante la terminación o bien por los efectos producidas por la misma.

En la primera situación la víctima no desea perder su fuente laboral por lo cual quedan descartadas las indemnizaciones típicas del derecho laboral y en este caso se deben adoptar medidas correctivas tendientes a eliminar la conducta de acoso (por ejemplo, separación de funciones, distribución de jornada, despido del acosador, etc.). En relación a esta hipótesis la jurisprudencia ha determinado distintas fórmulas tendientes a reparar los perjuicios del acoso, sin terminación contractual ${ }^{135}$. En esta primera situación, el daño se ha proyectado en la personalidad del trabajador, por lo que no cabe duda que la reparación del daño moral será el medio más idóneo para lograr el fin protector e inhibitorio de la regulación legal ${ }^{136}$.

Ahora bien, si el acoso tiene como consecuencia la terminación del contrato de trabajo, probablemente la sanción usual será la de condenar al empleador infractor a pagar las indemnizaciones típicas (indemnización sustitutiva del aviso previo y la indemnización por años de servicios ) lo que resulta notoriamente insuficiente y es por ello que si se reclama del acoso laboral como una hipótesis de vulneración de derechos fundamentales, el artículo 489 del CT faculta al juez para ordenar el pago de las indemnizaciones típicas y una adicional que fijará el sentenciador, la que no podrá ser inferior a seis meses ni superior a once meses de la última remuneración.

Esta indemnización adicional de ninguna forma es procedente durante la vigencia de la relación laboral dada la ubicación y redacción del texto legal antes mencionado. A esta indemnización es perfectamente posible adicionar el daño moral de acuerdo a la redacción del artículo $495 N^{\circ} 3$ del Código del Trabajo, al disponer que la sentencia recaída en el procedimiento de tutela debe indicar concretamente las medidas a que se encuentra obligado el infractor dirigidas a obtener la reparación de las consecuencias derivadas de la vulneración de derechos fundamentales, "incluidas las indemnizaciones que procedan". Esta última frase no distingue respecto de los daños que deben ser indemnizados, concluyéndose su alcance al daño moral. ${ }^{137}$

\footnotetext{
135 Ver Juzgado del Trabajo de Puente Alto, RIT No T-1-2010, fecha 10 de marzo de 2010. Se condenó a la empleadora a pagar la suma de $\$ 4.000 .000$, por los daños morales causados por el acoso, encontrándose vigente la relación laboral.

136 Desde otra perspectiva, el derecho comparado ha previsto la posibilidad de reparación del daño causado por conductas hostigatorias en el ámbito laboral, a través de las normas comunes de Responsabilidad. Al respecto, en Francia existe responsabilidad civil del empleador proveniente de daños por el acoso, en Holanda la víctima puede solicitar reparación indemnizatoria "bajo las leyes generales de responsabilidad", en Japón, la jurisprudencia ha ordenado indemnizaciones por daños punitivos, previstos en el Código Civil y por último, en Italia, la reparación debe cubrir todos los daños causados por el acoso laboral, entre ellos el daño biológico, el daño existencial y el daño moral. Finalmente se concluye que la acción regular por daños civiles muchas veces es el único camino para obtener reparación cuando no existe un régimen específico de responsabilidad laboral. Gamonal, Sergio; Ugarte, José Luis, "Acoso sexual... (n. 38), p. 38.

137 En relación a la fórmula para resarcir el daño ocasionado por una conducta hostigadora, el autor español Sagardoy expone que "Las indemnizaciones atienden a finalidades de política social y económica, y no se calculan en función exclusiva de los daños y perjuicios que sufre el trabajador por la pérdida del puesto de trabajo. Junto al carácter resarcitorio, las indemnizaciones poseen otro punitivo, de sanción al empresario por su proceder irregular". SAgardoy Bengoechea, Juan, op. cit. (n. 44), p. 104. Acerca de la reparación, MANGARELlı estima que "Debe aclararse que las indemnizaciones tarifadas no han sido obstáculo para admitir la reparación del daño por encima de la tarifa indemnizatoria, admitiénclose por ejemplo, en muchos países (Chile, Brasil, Uruguay) la reparación del daño moral por actos del empleador acontecidos durante la relación de trabajo o en el momento de su extinción. Pero sin violentar el sistema tarifado de indemnización, dado que con la reparación del daño moral se han indemnizado daños provenientes de actos ilícitos del empleador no cubiertos por la indemnización tarifada por despido". Mangarelli, Cristina. "Tendencias del derecho del trabajo", en: Revista Gaceta Laboral, vol. 15, n 1, pp. 87-100. Venezuela, Caracas, 2009.
} 
En esta línea estimamos -a diferencia de tesis jurisprudencial recepcionada y la doctrina al respecto - que la naturaleza de la indemnización regulada en el artículo 489 del Código del Trabajo, no tiene por objeto reparar los derechos fundamentales vulnerados, sino por el contrario, esta constituye una verdadera indemnización punitiva.

\section{EL ACOSO SEXUAL LABORAL}

\subsection{Sobre la noción de Acoso Sexual en el trabajo}

El desfase legal frente a lo sociolaboral y la insuficiencia de las normas al regular fenómenos sociales, culturales, políticos y económicos, ya es una característica propia del Derecho del Trabajo, lo que hace que las instituciones jurídicas primeramente comiencen a generarse desde el debate impulsado por la sociedad civil, para luego ser recepcionados -en mayor o menos medida- por la jurisprudencia y, posteriormente, desde la normatividad estatal.

Tal fenómeno no es ajeno al acoso sexual, el cual encuentra sus primeros antecedentes en la denuncia generalizada de los movimientos feministas norteamericanos en la década de los setenta, manifestándose en contra de las conductas de intromisión indeseada de los hombres en la vida de las mujeres, sin plantearse aún como una conducta exclusivamente de naturaleza sexual. Se trataba fundamentalmente de ciertas prácticas y actitudes discriminatorias que infantilizaban a las mujeres en el trabajo, obstaculizando de esta manera su integración o negando su valor como profesionales, lo cual produjo un efecto de visibilización de las relaciones de desigualdad y violencia en el seno de las relaciones entre mujeres y hombres, lo cual repercutió en el debate público y político $^{139}$.

Así, si bien la conducta de acoso sexual hoy es entendida en términos neutros, es inevitable indicar que históricamente evoca un conflicto de género que afecta principalmente al colectivo femenino $^{140}$. La cultura patriarcal asocia a las mujeres con la sexualidad, obligándolas a reflejarla en su forma de ser, de vestir o de comunicarse, reforzándolas como objeto de deseo, representación que se traslada al ámbito laboral ${ }^{141}$ el cual debido a la tipología de la relación laboral -determinada por la subordinación y dependencia-, se ve acrecentada, es más, se ha indicado que uno de los principales motivos "primarios subyacentes" son junto al deseo sexual, el obtener, afirmar o mantener poder y rango ${ }^{142}$. En esta situación las prácticas de acoso sexual expresan:

"Una cultura en que la masculinidad incluye la definición de las prácticas sexuales y el ejercicio de la sexualidad con prescindencia de la voluntad de las mujeres. Esta concepción de subordinación femenina cruza toda la sociedad y tiene expresión particular en el ámbito

\footnotetext{
139 Begoña Pernas (et al.). La dignidad quebrada. Las raíces del acoso sexual en el trabajo. Madrid, España: Fundación $1^{\circ}$ de Mayo Secretaría Confederal de la Mujer CC.OO, Los Libros de la Catarata, 2000, pp. 15 y ss.

140 Constatando tal realidad en Chile: FARÍAs, Pamela; Gómez, Marcela. Acoso sexual en el trabajo: de la impunidad a la acción. Aportes al Debate Laboral, $n^{\circ}$ 7. Santiago, Chile: Departamento de Estudios, Dirección del Trabajo, 1999; CARrasco OÑate, Celina; Vega López, Patricia. Acoso Sexual en el trabajo, ¿denunciar o sufrir en silencio? Análisis de denuncias. Santiago, Chile: Estudios de Dirección del Trabajo, 2009.

14) Carrasco Oñate, Celina; Vega López, Patricia, op. cit. (n. 140), pp. 19 y ss.

142 Stockdale, Janet. “Acoso Sexual en el Trabajo". En: Firth-Cozanes, J.; West, M.A. (Coords.). Las mujeres en el mundo del Trabajo. Madrid, España: Editorial Morata, 1993, p. 78 y ss.
} 
Álvaro Eduardo Domínguez Montoya, Patricio Eleodoro Mella Cabrera, Teodoro Rodolfo Walter Díaz / El acoso en el trabajo: algunos aspectos doctrinarios, jurisprudenciales y legales del acoso moral y sexual en Chile

del trabajo, donde no es ideológicamente clara la pertenencia de las mujeres por propio derecho sino que más bien son sólo aceptadas"143.

En tal esquema, el origen del reconocimiento institucional del acoso sexual no se produjo a modo de concesión graciosa, sino que fue un largo transito -en el que incluso con resistencia absoluta- de entender el acoso sexual como una cuestión que "se basaba en un atractivo físico, y no en el sexo de la demandante" o bien "de un enfrentamiento derivado de las sutilizas de una relación discordante" a un caso de discriminación sexual, encontrándose sus antecedentes en una construcción jurídica demanda por la sociedad civil norteamericana y grupos feministas ${ }^{144}$ en la que influyó notablemente los aporte teóricos de MACKINONN ${ }^{145}$ y FARLEY ${ }^{146}$, quienes asentaron en el constructo del acoso sexual la idea de la existencia de una discriminación por género con el objeto de obtener prestaciones sexuales, como así también como un forma de emplear el sexo como un medio para conservar el poder y status.

En tal contexto, en 1980 en Estados Unidos la Comisión para la Igualdad de Oportunidades en el Empleo otorgara un conjunto de pautas y reglas para sancionar el acoso sexual, definiéndolo como insinuaciones sexuales indeseadas, solicitudes de favores sexuales, $u$ otra conducta física $o$ verbal de naturaleza sexual cuando: 1) su cumplimiento se hace de manera explícita o implícita en términos o como condición para obtener el empleo; 2) su cumplimiento o la negación de su cumplimiento por un individuo es la base para tomar decisiones que afecten el empleo de dicho individuo, o 3) tales conductas tienen el propósito o efecto de interferir sin razón, en la eficiencia del trabajo de un individuo; o creando un ambiente de trabajo intimidatorio, hostil y ofensivo ${ }^{147}$, influyendo notablemente en las regulaciones de acoso sexual adoptadas a nivel occidental ${ }^{148}$.

Posteriormente en 1986, la Corte Suprema norteamericana en el caso "Banco de Ahorros Meritor con Vinson" determinó el acoso sexual como una de las conductas discriminatorias por sexo prohibidas en el Título VII, de la Ley de Derechos Civiles de 1964, sentencia que "da por inaugurada una inédita etapa de represión jurídica sobre este tipo de conductas en los países más avanzados del mundo" ${ }^{149}$.

A nivel internacional, según la OIT, el acoso sexual es "un comportamiento de carácter sexual no deseado por la persona afectada y que incide negativamente en su situación laboral provocándole un perjuicio"150.

En la Unión Europea, la Recomendación N 92/131, de 1991, relativa a la protección de la integridad de la mujer y del hombre en el trabajo, lo definió como:

\footnotetext{
143 Henrf́quez, Helia; Riquelme, Verónica. Asedio sexual en el trabajo. Una política para su erradicación. Temas Laborales $\mathrm{n}^{\circ}$ 6. Santiago, Chile: Departamento de Estudios, Dirección del Trabajo, 1997.

144 Begoña Pernas (et al.). op. cit. (n. 139), pp. 168 y ss.; Calle Fuentes, M.; González Romero; Núñez Triguero, J.A. Discriminación y acoso sexual a la mujer en el trabajo. Madrid, España: Largo Caballero, 1988, p.20; Sánchez, Cruz. Del Acoso Sexual. Aspectos penales. Madrid, España: Thompson Reuters, 2010, pp. 69 y ss.

145 Mackinnon, C.A. Sexual Harassment of Working Women:a cases of sex discrimination. New York, Estados Unidos: Yale University press, 1979.

146 FARLEY, L. Sexual Shakedown. New York, Estados Unidos: Warner Book, 1978.

147 Begoña Pernas (et al.). op. cit. (n. 139), p. 16.

148 Ibid., p. 169.

149 Lizama, Luis; Ugarte, José Luís. Nueva Ley de Acoso Sexual. Santiago, Chile: Lexis Nexis, 2005, p. 3.

150 Ver Daeren, Lieve. La OIT frente al acoso sexual. Santiago, Chile: Documento de trabajo, OIT-ETM, 1998.
} 
"La conducta de naturaleza sexual u otros comportamientos basados en el sexo que afecta a la dignidad de la mujer en el trabajo, incluida la conducta de superiores y compañeros si: (i) dicha conducta es indeseada, irrazonable y ofensiva para la persona objeto de las misma, (ii) la negativa o sometimiento de una persona a dicha conducta por parte de empresas o trabajadores (incluidos los superiores y compañeros) se utiliza de forma explícita o implícita como base para una decisión que tenga efectos sobre el acceso de dicha persona a la formación profesional y el empleo, sobre la continuación del mismo, los ascensos, el salario o cualesquiera otras decisiones relativas al empleo, (iii) dicha conducta crea un entorno laboral intimidatorio, hostil o humillante para la persona que es objeto de la misma, y que dicha conducta puede ser, en determinadas circunstancias, contraria al principios de igualdad de trato"151.

Por su parte, la directiva de la 2002/73/EC sobre tratamiento equitativo, lo definió como una discriminación y es prohibido en el empleo, incluyendo la etapa de contratación, formación y práctica profesional. Luego, la Directiva 2006/54/EC derogó la directiva del 2002 pero mantuvo idénticas las definiciones de acoso sexual. Por otro lado, la Directiva 2004/113EC amplió la prohibición de acoso sexual fuera del mercado de trabajo, amparando a todos los prestadores de bienes y servicios, tanto en los sectores públicos y privados. Estas directivas son generales, en el sentido de que cada estado miembro elige la forma de implementarlas en su derecho interno y las sanciones respectivas ${ }^{152}$.

\subsection{Regulación en el Ordenamiento Jurúdico Chileno del Acoso Sexual Laboral}

En nuestro país la figura del acoso sexual aparece con la Ley $\mathrm{N}^{\circ} 20.005$, de 18 de marzo de 2005, la cual "tipifica y sanciona el acoso sexual", siendo producto de un largo tránsito legislativo ${ }^{153}$ en el que incluso, sin la existencia de legislación expresa, la jurisprudencia de la época comenzó a reconocer tal figura como una infracción contractual ${ }^{154}$.

Sobre el punto se introdujeron sendos cambios a nuestro ordenamiento jurídico, destacándose la incorporación de un concepto de acoso sexual laboral ${ }^{155}$; el establecimiento de una obligación genérica ${ }^{156}$ y otras específicas ${ }^{157}$ en el Reglamento Interno sobre la materia, destacándose

151 Cita de Lizama, Luis; Ugarte, José Luís, Nueva Ley (n. 149), pp. 11 y ss.

152 Referencia tomada del Informe sobre "Acoso sexual y moral en el lugar de trabajo" en: XX Congreso Mundial del Derecho del Trabajo y la Seguridad Social, realizado en Santiago, Chile, septiembre de 2012, realizado por los relatores Sergio Gamonal Contreras y José Luis Ugarte Cataldo.

153 El proyecto de ley que posteriormente dio a lugar la citada ley, ingreso al congreso con fecha 24 de octubre de 1994.

154 Un emblemático caso lo representa el pronunciamiento de la Corte Suprema en Chile sobre acoso sexual que sanciona al empleador a pagar indemnización por término de contrato. "Giovanna Riveri Cerón con Fucoa" Rol 2.704-02. Empleador no ejecuto las acciones que le correspondían para impedir el acoso sexual a una trabajadora, que lleva fecha 9 de abril de 2003.

155 Artículo $2^{\circ}$ inciso $2^{\circ}$ del Código del Trabajo: "Las relaciones laborales deberán siempre fundarse en un trato compatible con la dignidad de la persona. Es contrario a ella, entre otras conductas, el acoso sexual, entendiéndose por tal el que una persona realice en forma indebida, por cualquier medio, requerimientos de carácter sexual, no consentidos por quien los recibe y que amenacen o perjudiquen su situación laboral o sus oportunidades en el empleo."

156 Artículo 153 inciso segundo del Código del Trabajo, "Especialmente, se deberán estipular las normas que se deben observar para garantizar un ambiente laboral digno y de mutuo respeto entre los trabajadores."

157 Artículo 154 No 12 del Código del Trabajo: "El procedimiento al que se someterán y las medidas de resguardo y sanciones que se aplicarán en caso de denuncias por acoso sexual. 
Álvaro Eduardo Domínguez Montoya, Patricio Eleodoro Mella Cabrera, Teodoro Rodolfo Walter Díaz / El acoso en el trabajo: algunos aspectos doctrinarios, jurisprudenciales y legales del acoso moral y sexual en Chile

entre estas la creación de un procedimiento especial de investigación para resolver las cuestiones de acoso sexual ${ }^{158}$; la incorporación de una nueva causal de despido disciplinario ${ }^{159}$ y una regulación específica respecto de la terminación por esta vía ${ }^{160}$.

\subsubsection{Concepto, clases, sujeto del acoso sexual en Chile}

En nuestro país el concepto legal se encuentra en el artículo 2 de nuestro Código del Trabajo. En su inciso segundo se indica que:

"Las relaciones laborales deberán siempre fundarse en un trato compatible con la dignidad de la persona. Es contrario a ella, entre otras conductas, el acoso sexual, entendiéndose por tal el que una persona realice en forma indebida, por cualquier medio, requerimientos de carácter sexual, no consentidos por quien los recibe y que amenacen o perjudiquen su situación laboral o sus oportunidades en el empleo".

En el caso de las denuncias sobre acoso sexual, el empleador que, ante una denuncia del trabajador afectado, cumpla integramente con el procedimiento establecido en el Título IV del LIBRO II, no estará afecto al aumento señalado en la letra c) del inciso primero del artículo 168,"

158 Se crea el Título IV DE LA INVESTIGACION Y SANCIÓN DEL ACOSO SEXUAL, el cual tiene el siguiente articulado: Art. 211-A. En caso de acoso sexual, la persona afectada deberá hacer llegar su reclamo por escrito a la dirección de la empresa, establecimiento o servicio o a la respectiva Inspección del Trabajo.

Art. 211-B. Recibida la denuncia, el empleador deberá adoptar las medidas de resguardo necesarias respecto de los involucrados, tales como la separación de los espacios físicos o la redistribución del tiempo de jornada, considerando la gravedad de los hechos imputados y las posibilidades derivadas de las condiciones de trabajo.

En caso que la denuncia sea realizada ante la Inspección del Trabajo, ésta sugerirá a la brevedad la adopción de aquellas medidas al empleador.

Art. 211-C. El empleador dispondrá la realización de una investigación interna de los hechos o, en el plazo de cinco días, remitirá los antecedentes a la Inspección del Trabajo respectiva.

En cualquier caso la investigación deberá concluirse en el plazo de treinta días.

Si se optare por una investigación interna, ésta deberá constar por escrito, ser llevada en estricta reserva, garantizando que ambas partes sean oídas y puedan fundamentar sus dichos, y las conclusiones deberán enviarse a la Inspección del Trabajo respectiva. Art. 211-D. Las conclusiones de la investigación realizada por la Inspección del Trabajo o las observaciones de ésta a aquélla practicada en forma interna, serán puestas en conocimiento del empleador, el denunciante y el denunciado.

Art. 211-E. En conformidad al mérito del informe, el empleador deberá, dentro de los siguientes quince días, contados desde la recepción del mismo, disponer y aplicar las medidas o sanciones que correspondan.

159 Artículo $160 \mathrm{~N}^{\circ} 1$ letra b), quedando configurado de la siguiente forma: El contrato de trabajo termina sin derecho a indemnización alguna cuando el empleador le ponga término invocando una o más de las siguientes causales:

1. Alguna de las conductas indebidas de carácter grave, debidamente comprobadas, que a continuación se señalan: B) “Conductas de acoso sexual".

160 Se intercalan las siguientes disposiciones:

Artículo 168 inciso $3^{\circ}$ del Código del Trabajo: "En el caso de las denuncias de acoso sexual, el empleador que haya cumplido con su obligación en los términos que señalan el artículo 153, inciso segundo, y el Título IV del LIBRO II, no estará afecto al recargo de la indemnización a que hubiere lugar, en caso de que el despido sea declarado injusto, indebido o improcedente."

Artículo 171 inciso $2^{\circ}$ del Código del Trabajo: "Tratándose de la aplicación de las causales de las letras a), b) y f) del número 1 del artículo 160, el trabajador afectado podrá reclamar del empleador, simultáneamente con el ejercicio de la acción que concede el inciso anterior, las otras indemnizaciones a que tenga derecho."

Artículo 171 inciso $3^{\circ}$ del Código del Trabajo: "Cuando el empleador no hubiera observado el procedimiento establecido en el Título IV del LIBRO II, responderá en conformidad a los incisos primero y segundo precedentes"

Artículo 171 inciso final del Código del Trabajo: "Si el trabajador hubiese invocado la causal de la letra b) o f) del número 1 del artículo 160, falsamente o con el propósito de lesionar la honra de la persona demandada y el tribunal hubiese declarado su demanda carente de motivo plausible, estará obligado a indemnizar los perjuicios que cause al afectado. En el evento que la causal haya sido invocada maliciosamente, además de la indemnización de los perjuicios, quedará sujeto a las otras acciones legales que procedan". 
Palavecino indica -en orden a la delimitación material de la "fenomenología del acoso sexual laboral"- cuatro hipótesis que engloban tal concepto:

“1) La petición de favores sexuales conectada a una promesa de mejora de las condiciones de trabajo del solicitado, si éste acepta, y/o a una amenaza de menoscabo de tales condiciones, o derechamente de despido, si aquél la rechaza; 2) La petición insistente de favores sexuales, en el lugar de trabajo, sin tomar en cuenta el rechazo manifiesto del solicitado; 3) La realización reiterada de conductas, comentarios o alusiones de carácter sexual en el lugar de trabajo, sin tomar en cuenta su ofensividad para otro; y 4) Las conductas descritas en los casos 2 y 3 , ejecutadas de forma sistemática y recurrente durante un tiempo prolongado con el propósito de determinar a la víctima a dejar su trabajo mediante una fórmula alternativa que cree la apariencia de autoexclusión"161.

De la anterior delimitación se pueden distinguir dos tipos de acoso sexual: "chantaje sexual" y "acoso sexual ambiental".

Se ha dicho que chantaje sexual ${ }^{162}$-o acoso quid pro quo- es una forma de hostigamiento sexual que "fuerza a un trabajador a elegir entre someterse a los requerimientos sexuales o perder o ver perjudicados ciertos beneficios o condiciones del trabajo"163. En tal hipótesis "se requiere que el acosador tenga una ubicación jerárquica superior a la víctima, existiendo un ejercicio abusivo del poder en el ámbito laboral"164.

Por su parte, acoso sexual ambiental es aquel en que:

"El acoso se constituye por una conducta de hostigamiento sexual que generan para la víctima un entorno laboral humillante y hostil, sin que se requiera que el acosador ofrezca ventajas laborales de ningún tipo. A diferencia del anterior este tipo de acoso sexual puede tener como sujeto activo o victimario a un compañero de trabajo no superior jerárquicamente." ${ }^{165}$

En otro plano, se ha clasificado ${ }^{166}$ el acoso sexual como horizontal y vertical. Se entiende por acoso sexual horizontal "aquel que se origina entre compañeros de trabajo de igual jerarquía $y$ aún en casos en que el acosador tiene menor jerarquía" y acoso sexual vertical como "aquel que

\footnotetext{
161 Palavecino Cáceres, Claudio. "El nuevo ilicito de acoso sexual en el derecho del trabajo chileno", en: Revista de Derecho, n' 19, pp. 105-123. Valdivia, Chile: Facultad de Derecho, Universidad Austral de Chile, 2006.

162 PALAvecino -siguiendo a Bascuñan- indica que tal calificación es del todo impropia, por cuanto por "chantaje" se entiende en sentido propio un caso especial de coerción mediante amenaza, caracterizado por la particular naturaleza del medio empleado y el fin perseguido: en el chantaje se amenaza con revelar información confidencial para obtener un provecho patrimonial. Ninguna de estas dos características se cumplen en el acoso sexual. La víctima de chantaje debe pagar dinero para asegurar el silencio; en cambio, la víctima del acoso sexual coercitivo debe realizar un acto sexual para no sufrir un perjuicio relacionado con su actividad laboral. Ibid., p. 107.

163 CaAmaño, Eduardo. “Acoso Sexual: concepto, clases y bien jurídico protegido”. En su: El acoso sexual en la empresa. Análisis de la ley 20.005. Santiago, Chile: Lexis Nexis, 2005, p. 12.

164 Lizama, Luis y UGARTE, José Luís, op.cit. (n. 149), pp.12 y 13

165 Ibid., p.13.

Orden de Servicio $\mathrm{N}^{\circ} 8$ de la Dirección del Trabajo, de fecha 3 de julio de 1997.
} 
Álvaro Eduardo Domínguez Montoya, Patricio Eleodoro Mella Cabrera, Teodoro Rodolfo Walter Díaz / El acoso en el trabajo: algunos aspectos doctrinarios, jurispridenciales y legales del acoso moral y sexual en Chile

se configura por conductas de superiores jerárquicos de la afectada, sea el empleador o un mando superior".

En cuanto a los sujetos activos del acoso sexual, existe consenso doctrinario en que el acosador puede ser tanto un superior jerárquico (acoso vertical) o bien compañeros de trabajo (acoso horizontal) o incluso englobar a trabajadores de inferior jerarquía (figura subsumible dentro del acoso ambiental y horizontal en términos más amplios). En efecto, "el acoso no es necesariamente un abuso de poder al interior de una relación de poder, sino un hostigamiento lesivo de la dignidad de la persona que puede configurarse entre sujetos ubicados en planos de igualdad jerárquica, dando lugar al denominado acoso ambiental u horizontal"167.

Sobre el punto existe claridad en reconocer como sujeto activo cualquier trabajador con independencia de su categoría, rango o jerarquía, teniendo en particular consideración lo previsto en el artículo $2^{\circ}$ del Código del Trabajo y el artículo 160 No 1 letra B) como hipótesis de despido disciplinario que configuran una noción más amplia de menoscabo en las condiciones de trabajo, las cuales evidencian que pueden verse perjudicas por un grupo de trabajadores que no necesariamente ejerzan funciones o tareas como superiores jerárquicos del acosado ${ }^{168}{ }_{-}^{169}$.

Respecto del sujeto pasivo, no existe duda que claramente debe ser un trabajador el cual para efectos de la figura en comento, es indistinta la jerarquía que tenga dentro de la organización empresarial, cuestión que se extrae de consideraciones doctrinarías y de texto, por cuanto no existe una suerte de sujeto pasivo calificado por su puesto de trabajo, sino que basta que sea trabajador en los términos del artículo $3^{\circ}$ del Código del Trabajo, como así también respecto de aquellos que se hace extensiva la legislación laboral.

Por otro lado, respecto del género del sujeto pasivo no existe distinción alguna, por lo que este puede ser tanto un hombre como una mujer.

Sobre la conducta esta debe consistir en un comportamiento sexual o de connotación sexual, indeseada por el sujeto pasivo, la cual debe producir una amenaza o un perjuicio en su situación laboral o en sus oportunidades de empleo.

a) Comportamiento sexual o de connotación sexual

Comportamiento debe entenderse "en un sentido amplio que comprenda acciones de carácter verbal, escrito, gestual o de contacto físico" ${ }^{170}$. En efecto:

"Las conductas constitutivas de acoso no se encuentran limitadas a acercamientos o contactos físicos, sino que incluye cualquier acción del acosador sobre la victima que pueda representar un requerimiento de carácter sexual indebido, incluyendo en ese sentido, pro-

167 Lizama, Luis y Ugarte, José Luís, op.cit. (n. 149), p 13 y ss. Palavecino estima que la figura de Acoso Sexual Ambiental no es un figura reconocida en nuestro ordenamiento jurídico, sino cuando "conllevan una invitación dirigida a quien los padece de satisfacer una pretensión o un deseo sexual", Palavecino, Claudio, "El nuevo ilícito... (n. 161), p. 115.

168 Palavecino, Claudio, “El nuevo ilícito... (n. 161), p. 115.

169 Se ha dicho por la jurisprudencia -resolviendo la aplicación de causal de despido disciplinaria del $160 \mathrm{n}^{\circ} 1$ letra b) del C.T.que "el trato compatible con la dignidad de las personas, exigido en toda relación laboral por el inciso segundo del artículo $2^{\circ}$ del Código del Trabajo, no sólo es exigible entre empleador y trabajador, sino también entre los trabajadores que laboran para el mismo empleador". Sentencia Corte de Apelaciones de Santiago, 24 de febrero de 2010, ROL N 6358-2009. Por su parte se ha dicho que -al momento de distinguir los tipos de acoso sexual- que "se infiere que la legislación actual, regula ambos tipos de acoso, al emplear la expresión "que amenacen o perjudiquen su situación laboral o su oportunidad en el empleo". Sentencia Corte de Apelaciones de Santiago, 27 de mayo de 2008, ROL $N^{\circ}$ 4475-2007.

170 Palavecino, Claudio, "El nuevo ilícito... (n. 161), p. 108. 
puestas verbales, correos electrónicos, cartas o misivas personales, que amenacen o perjudiquen su situación laboral o sus oportunidades en el empleo"171.

En tal esquema, la conducta de acoso sexual puede ser física, verbal o no verbal. Así, se considera comúnmente que la conducta física de naturaleza sexual equivale al contacto físico no deseado que varía desde tocamientos innecesarios, palmaditas o pellizcos o roces con el cuerpo, las que "gran parte de estas equivaldría a un delito penal si tuviera en la calle entre desconocidos"172. Por conducta verbal de naturaleza sexual, consiste en incluir situaciones sexuales molestas, proposiciones o presión para actividades sexuales, como así también insistencia para una actividad social fuera del lugar de trabajo después de que se haya puesto en claro que dicha insistencia es molesta, flirteos ofensivos, comentarios insinuantes, indirectas o comentarios obscenos ${ }^{173}$. Por conductas no verbales de naturaleza sexual, se refiere a la exhibición de fotos sexualmente sugestivas o pornográficas, de objetos materiales escritos; miradas impúdicas, silbidos, o hacer gestos que hacer pensar o tienen la connotación social de sexuales ${ }^{174}$.

En cuanto a la continuidad o permanencia del comportamiento, se ha dicho que:

"No es necesario que la conducta de acoso sea reiterada en el tiempo, basta que sea lo suficientemente intensa para afectar a la víctima, aunque sólo se produzca por una sola ocasión. Especialmente, en lo que hemos denominado acoso quid pro quo o de chantaje, donde una sola exigencia de carácter sexual bajo amenaza basta para que la conducta sea suficiente para configurar el acoso sexual sancionado por la ley"175.

Es más, la doctrina al caracterizar el acoso laboral lo ha diferenciado respecto del acoso sexual en cuanto "el acoso moral, que requiere un conjunto de conductas, el acoso sexual puede estar constituido por una sola, sin perjuicio que es posible que se produzca una escala de conductas constitutivas de acoso sexual. Siendo así, no todo acoso sexual es acoso moral o mobbing"176_177.

Ahora, respecto de la connotación o carácter sexual de la conducta se sitúa en un plano subjetivo/objetivo, las cuales deben ser determinadas por el contexto de la relación laboral misma y las particularidades del sujeto pasivo, en la cual debe tenerse en cuenta la actitud del acosado frente a los requerimientos. En tal caso nos inclinamos por un criterio de subjetivo matizado, en el sentido que lo primordial debe ser si la conducta tuvo el efecto de crear un ambiente hostil a la persona acosada, recayendo el estándar en la percepción de esta última.

\footnotetext{
171 Dictamen $\mathrm{N}^{\circ} 1133 / 36$, de 21 de marzo de 2005.

172 OIT. La lucha contra el acoso sexual en el trabajo. Madrid, España: Instituto Nacional de Seguridad e Higiene en el Trabajo, GETAFE, p. 18.

173 Ibid.

174 Ibid.

175 Lizama, Luis; Ugarte, José Luís, op.cit. (n. 149), p. 16.

${ }_{176}$ Prado López, Pamela, "Breves reflexiones en torno al mobbing", en: Revista Laboral Chilena, Julio, pp. 91-98. Santiago, Chile, 2005. En el mismo sentido Gamonal Contreras, Sergio; Prado López, Pamela, op, cit. (n. 6) p. 36 y ss.

177 Erradamente se ha extrapolado el mismo criterio que del acoso laboral al acoso sexual. Se ha dicho que "el acoso sexual debe necesariamente implicar conductas, es decir, varias, no se trata de hechos aislados, deben ser de connotación sexual no deseados por la afectada y, que amenace su situación laboral, entendiendo la jurisprudencia que va dirigido en el sentido de producir un ambiente laboral hostil, incómoda, desagradable para el acosado o afectado con tales conductas." Sentencia del Juzgado de Letras de San Bernardo, 11 de enero de 2010, RIT T-08-2009.
} 
Álvaro Eduardo Domínguez Montoya, Patricio Eleodoro Mella Cabrera, Teodoro Rodolfo Walter Díaz / El acoso en el trabajo: algunos aspectos doctrinarios, jurisprudenciales y legales del acoso moral y sexual en Chile

\section{b) Es una conducta indeseada por el sujeto afectado}

Evidentemente los requerimientos no tienen que ser consentidos por la víctima. El elemento configurativo esencial es la indeseabilidad de la conducta sexual para el afectado, siendo fundamental la exteriorización de la negativa del requerimiento.

Sobre el punto una cuestión problemática es la forma en que debe manifestarse el rechazo. Se ha dicho que tal debe ser "una reacción inmediata, explícita y categórica de la víctima"178, por otro lado se ha matizado dicha exigencia, indicando que "el rechazo no requiere una acción frontal y explícita de la víctima, basta que del contexto en que se produce se deduzca inequívocamente la no aceptación del requerimiento, por ejemplo, denunciar la situación al empleador, no contestar las insinuaciones, comunicar los hechos al sindicato, etc."179.

Sin embargo, tal actitud no siempre puede ser exigible, ya que en aquellas hipótesis de acoso sexual coercitivo ${ }^{180}$ :

"El sujeto activo está en una posición de poder en relación con el sujeto pasivo, posición desde la cual puede adoptar decisiones desfavorables en relación con las condiciones de trabajo de la víctima. Un justificable temor de represalias laborales puede inhibir al acosado de adoptar una conducta activa, de rotundo e instantáneo rechazo, ante los avances o requerimientos del superior. En tales circunstancias la indeseabilidad puede también manifestarse a través de un comportamiento evasivo o dilatorio de la víctima.

No se debería, pues, hacer recaer todo el peso de la determinación de este elemento en la actitud que adopte el acosado"181.

c) Se produzca una amenaza o un perjuicio en su situación laboral o en sus oportunidades de empleo

A la caracterización anterior, quisiéramos agregar un matiz propio de nuestro ordenamiento jurídico. Nuestro concepto legal de acoso sexual incluye una redacción que pareciera ser que exige o configura, una especie de ilícito de resultado al señalar que las conductas sexuales o de connotación sexual "amenacen o perjudiquen su situación laboral o sus oportunidades en el empleo".

Se ha dicho por la Dirección del Trabajo que la ley ha entendido que:

"Al utilizar la expresión "amenacen o perjudiquen su situación laboral", que se configura la conducta de acoso sexual no sólo cuando la persona afectada sufre un perjuicio o daño laboral directo en su situación al interior de la empresa, sino que también cuando por la creación de un ambiente hostil y ofensivo de trabajo, se pone en riesgo su situación laboral u oportunidades en el empleo"182.

\footnotetext{
178 Ibid., p. 109

179 Lizama, Luis; Ugarte, José Luís, op.cit. (n. 149), p. 16

180 Esto es "la petición de favores sexuales conectada a una promesa de mejora de las condiciones de trabajo del solicitado, si éste acepta, y/o a una amenaza de menoscabo de tales condiciones, o derechamente de despido, si aquél la rechaza".

181 Palavecino, Claudio, "El nuevo ilícito... (n. 161), p. 110.

182 Dictamen $\mathrm{N}^{\circ}$ 1133/36, de 21 de marzo de 2005.
} 
En la misma línea y a pesar de las dudas que podría generar su redacción literal, es indudable que nuestra ley sanciona no sólo el chantaje sexual sino también el ya señalado acoso ambiental.

En efecto, "precisamente, la creación de un ambiente hostil y humillante de trabajo, como ocurre en este tipo de acoso, importa indefectiblemente una lesión o perjuicio a la situación laboral de la víctima"183. Esta última hipótesis se ve reforzada por lo dispuesto en el artículo 153 del Código del Trabajo que obliga al empleador a "garantizar un ambiente laboral digno y de mutuo respeto entre los trabajadores", lo cual determina un reconocimiento al acoso sexual ambiental que no necesariamente exige un resultado para su materialización.

\subsubsection{Fundamentos y bienes juridicos protegidos}

En cuanto el fundamento de la regulación del acoso sexual se encuentra- al igual que en materia de acoso moral o mobbing- en el reconocimiento y la eficacia de los derechos fundamentales en las relaciones de trabajo, por cuanto es un ilícito que sanciona una hipótesis pluriofensiva de derechos fundamentales. Es más, la doctrina ha dicho que en "pocas actuaciones en el ámbito de la relación de trabajo implican una violación simultánea de tantos derechos fundamentales constitucional y legalmente reconocidos" ${ }^{\prime \prime 84}$.

En específico, la doctrina nacional mayoritaria ${ }^{185}$ entiende que la tipificación del Acoso Sexual en nuestro país sanciona una conducta que constituye un:

"Atentando contra sus derechos fundamentales referidos a la dignidad de la persona (artículo $1^{\circ}$ inciso $1^{\circ}$ Constitución Política de la Republica), a la intimidad (artículo $19 \mathrm{~N}^{\circ} 4$ Constitución Política de la Republica), a la no discriminación (artículo 19 № 16 inciso tercero Constitución Política de la Republica, en concordancia con el artículo 19 № 2 Constitución Política de la Republica y, a la vida y a la integridad física y psíquica (artículo $19 \mathrm{~N}^{\circ}$ 1 Constitución Política de la Republica) ${ }^{186}$.

a) La dignidad

Respecto a la infracción a la dignidad en el caso de conducta de acoso sexual laboral, debemos decir "que los comportamientos o conductas constitutivos de acoso sexual en el trabajo conllevan claramente una vulneración de la dignidad de la trabajadora o del trabajador que es víctima del acoso, toda vez que la dignidad es a tal punto configurativa de la personalidad, que lesionarla u ofenderla:

\footnotetext{
183 En el mismo sentido Lizama, Luis; Ugarte, José Luís, op.cit. (n. 149), pp. 16 y 17.

184 Cita de Palavecino, Claudio, "El nuevo ilícito... (n. 161), p. 111.

185 Lizama, Luis; Ugarte, José Luís, op.cit. (n. 149), pp. 3 y ss.; Rojas, Irene. “Por qué se debe legislar sobre el acoso sexual?”, en: Revista Laboral Chilena, Mayo. Santiago, Chile, 1998, pp. 68 y ss.; Dictamen $N^{\circ} 1133 / 36$, de 21 de marzo de 2005 . En contra Palavecino Cáceres, Claudio. "El nuevo ilícito... (n. 161), p. 114, no obstante que reconoce que los bienes jurídicos infringidos -en un nivel doctrinario-son los mismos indicados anteriormente.
}

186 CaAmaño, Eduardo, "Acoso Sexual: concepto ... (n. 163)., p. 25. 
Álvaro Eduardo Domínguez Montoya, Patricio Eleodoro Mella Cabrera, Teodoro Rodolfo Walter Díaz / El acoso en el trabajo: algunos aspectos doctrinarios, jurisprudenciales y legales del acoso moral y sexual en Chile

"Equivale a infundir en el sujeto consciente la incertidumbre, el desconcierto o la amargura. Es tratar a la persona inconsciente o mermada en su capacidad intelectiva, o privada de libertad personal como objeto físico, mutilado de su imperecedera calidad de ser humano. Conlleva angustia, síndromes traumáticos o la desesperanza más devastadora de la autoestima que se requiere para emprender, realizar o seguir un proyecto de vida personal" ${ }^{\prime 187}$.

Es más, en nuestra legislación existe una alusión expresa a tal idea en el artículo $2^{\circ}$ de nuestro Código del Trabajo, "las relaciones laborales deberán siempre fundarse en un trato compatible con la dignidad de la persona. Es contrario a ella, entre otras conductas, el acoso sexual".

\section{b) La intimidad}

Respecto de la infracción a la intimidad, se ha dicho que:

"El acoso sexual en el trabajo implica un manifiesto atentado contra la intimidad de la trabajadora o del trabajador que es víctima del hostigamiento, pues estas conductas implican invadir, contra su deseo y voluntad, una esfera esencialmente privada y reservada de la persona, como lo es su sexualidad, abusando de una posición de poder o de un ambiente laboral hostil que repercute negativa y perjudicialmente en la víctima"188.

Cuestión así reconocida por la jurisprudencia ${ }^{189}$, incluso es más, se ha entendido que "el tipo parece dirigirse únicamente a la protección del bien jurídico de la libertad sexual, entendida como "aquella parte de la libertad referida al ejercicio de la propia sexualidad y, en cierto modo, a la disposición del propio cuerpo"190.

\section{c) Derecho a la no discriminación}

Recordemos que el derecho a la no discriminación ${ }^{191}$, consiste en la garantía que asiste a los trabajadores y trabajadoras a no ser objeto de diferencias de trato no razonables o sin justificación objetiva.

187 CAamaño, Eduardo. "El bien jurídico protegido frente a los actos de acoso sexual en el lugar de trabajo", en: Revista de Derecho $\mathrm{N}^{\circ}$ 25, pp. 105 y ss. Valparaíso, Chile: Escuela de Derecho, Pontificia Universidad Católica de Valparaíso, 2004.

188 CaAmaño, Eduardo, “Acoso Sexual: concepto ... (n. 163), pp. 30 y 31.

189 "Ha sido vulnerado cuando el empleador ha accedido a la esfera más privada de las trabajadoras, cual es su propio cuerpo, al realizar tocaciones y avances no permitidas por la trabajadora, efectuando requerimientos de tipo sexual, que al ser efectuados bajo la amenaza tácita de represalias afectan también al libertad sexual de la trabajadora, libertad sexual que forma parte de la intimidad y la honra de la trabajadora, inmiscuyéndose así el empleador, de manera ilegítima en una esfera de la vida y de la propia personalidad de la trabajadora, que se encuentra fuera del ámbito laboral y a la que sólo es posible acceder cuando ello se es expresamente autorizado o invitado a ello." Sentencia del $2^{\circ}$ Juzgado de Letras del Trabajo de Santiago, 16 de abril de 2010 , RIT T-16-2010.

190 Señala Palavecrno que "A esta conclusión lleva, por una parte, el que la acción típica consista en realizar "requerimientos de carácter sexual", vale decir, solicitar favores de tal naturaleza y, por otra, la exigencia que tales requerimientos no sean consentidos por su destinatario." Incluso el autor estima que "tal como está redactado, el tipo aparece estructurado claramente como un atentado contra un bien jurídico específico: la libertad sexual de la víctima. Por tanto, no veo cómo se pueda extraer de la norma el pródigo listado de bienes jurídicos que ofrecen los comentaristas nacionales". Palavecino, Claudio, "El nuevo ilícito... (n. 161) p. 114.

191 Sobre el punto ver: CAAmaño, Eduardo. El derecho a la no discriminación en el empleo. Santiago, Chile: AbeledoPerrot, 2007; UgarTe, José Luis. El Derecho a la no discriminación en el trabajo. Santiago, Chile: Legalpublishing, 2013. 
En relación a lo anterior, se debe tener en cuenta que "en la práctica, el acoso sexual en el trabajo afecta a un número infinitamente superior de mujeres que de hombres, siendo evidente que en la inmensa mayoría de los casos la víctima no hubiera sido importunada si hubiese pertenecido al sexo masculino"192. En efecto:

"El acoso sexual conlleva una situación en la que la víctima casi siempre es mujer, por lo que este comportamiento debe caracterizarse también como expresión de una cultura que discrimina a las mujeres y les asigna un rol subordinado en el mundo del trabajo. Para este criterio, el acoso sexual supone una situación de discriminación en la que una mujer, sólo por el hecho de serlo, puede ser objeto de asedio sexual, exponiéndose a situaciones que amenazan su trabajo y su integridad física y psíquico" ${ }^{193}$.

Por lo que en si el asedio sexual constituye, además, una conducta discriminatoria por género, no obstante que conceptualmente y jurídicamente sean distintas.

d) Integridad física y síquica

En un plano más objetivo y cuantificable, la conducta de acoso sexual infringe el Derecho a la integridad física y síquica de toda persona, por cuanto la conducta hostigadora se constituye como una "fuente de deterioro psicológico para la víctima -produciendo efectos tales como ansiedad, tensión, irritabilidad, incapacidad de concentración, insomnio, fatiga, dolores de cabeza y otras manifestaciones de estrés- e inclusive en causa de lesiones corporales"194.

\subsubsection{Las obligaciones del empleador en materia de acoso sexual}

Respecto de las obligaciones que ha fijado la ley en materia de acoso sexual al empleador podemos desprender a lo menos 2 de carácter general: A) El deber de protección en materia de acoso sexual y el establecimiento de normas de para su prevención y B) La regulación de un procedimiento frente al acoso sexual, las medidas de resguardo y régimen de sanciones.

\subsubsection{El deber de protección en materia de acoso sexual y el establecimiento de normas para su prevención}

Una de las principales y genéricas obligaciones del empleador en materia de acoso sexual consiste en mantener un ambiente laboral digno y de mutuo respeto entre los trabajadores que prevenga el acoso sexual en sentido amplio, la cual viene dada por expresa regulación del artículo 153 inciso $3^{\circ}$ del Código del Trabajo ${ }^{195}$ que indica que en el Reglamento Interno "especialmente, se deberán estipular las normas que se deben observar para garantizar un ambiente laboral digno y de mutuo respeto entre los trabajadores", obligación que se desprende por lo demás del artículo $2^{\circ}$ y 154 inciso $2^{\circ}$ del Código del Trabajo, el cual fija como eje central el respeto a la dignidad del trabajador.

\footnotetext{
192 Pérez Del Río, Teresa. "El acoso sexual en el trabajo: su sanción en el orden social”, en: Relaciones Laborales, $\mathrm{n}^{\circ} 2, \mathrm{p} .187$. Madrid, España, 1990.

193 CaAmaño, Eduardo, “El bien jurídico... (n. 187), p. 110.

194 Palavecino, Claudio, “El nuevo ilícito... (n. 161), p. 112.

195 Se ha dicho por la doctrina que tal norma consagra el reconocimiento del acoso sexual ambiental. LizAMA, Luis; UGARTE, José Luís, op.cit. (n. 149) pp. 19 y ss.
} 
Álvaro Eduardo Domínguez Montoya, Patricio Eleodoro Mella Cabrera, Teodoro Rodolfo Walter Díaz / El acoso en el trabajo: algunos aspectos doctrinarios, jurispridenciales y legales del acoso moral y sexual en Chile

Lo anterior y como lo venía señalando la jurisprudencia con anterioridad a la legislación actual ${ }^{196}$, se deriva o encuentra su fundamento en la obligación de seguridad del artículo 184 del Código del Trabajo y el contenido ético del contrato de trabajo, que configuran la protección de la personalidad del trabajador como un elemento característico del contrato de trabajo.

Una segunda obligación -que da contenido específico a la anterior- es la obligación del empleador de incorporar normativa específica para la prevención de acoso sexual en la empresa.

En cuanto a su contenido, se recomienda por la doctrina algunas estipulaciones en el reglamento interno como: a) La empresa no tolerará ni permitirá el acoso sexual en sus centros de trabajo, ya sea como chantaje sexual o acoso ambiental; b) Los trabajadores tienen derecho a denunciar estas conductas conforme al procedimiento previsto si ellas se producen; $c$ ) Los gerentes tienen la obligación de asegurar que no se produzcan actos de acoso sexual; d) La empresa seguirá los procedimientos establecidos en el reglamento interno para investigar las denuncias presentadas; e) La empresa adoptará las medidas de resguardo para las víctimas y las sanciones a los responsables; f) La empresa garantiza que no existirán represalias para las personas que denuncien estos hechos ${ }^{197}$.

De igual forma se ha dicho, siguiendo el Código Práctico de Conducta para Combatir el Acoso Sexual en la Empresa propuesto por la Comisión Europea ${ }^{198}$ que la empresa de adoptar medidas frente al acoso sexual como: a) Declaración de principios; b) Definición de acoso sexual; c) La explicitación del procedimiento a seguir por las víctimas; d) La garantía a los trabajadores de la política de la empresa frente al acoso sexual; e) La garantía de un ambiente de trabajo respetuoso e instruir a los mandos medios y trabajadores en igual sentido; f) La capacitación de los mandos medios como posibles receptores de denuncias de acoso sexual ${ }^{199}$.

\subsubsection{La regulación de un procedimiento frente al acoso sexual, las medidas de resguardo y régimen de sanciones}

El empleador deberá regular un procedimiento frente al acoso sexual, las medidas de resguardo y régimen de sanciones.

Esta obligación tiene expresa consagración en nuestro ordenamiento jurídico, debiendo el empleador establecer normas internas que establezcan el procedimiento, las medidas de resguardo y sanciones que se aplicarán en caso de denuncias por acoso sexual, de acuerdo a lo establecido en el artículo $154 \mathrm{n}^{\circ} 12$ del Código del Trabajo. Dispone tal artículo que el Reglamento Interno deberá contener "El procedimiento al que se someterán y las medidas de resguardo y sanciones que se aplicarán en caso de denuncias por acoso sexual."

La ley además regula los mínimos que debe cumplir tal procedimiento, al consagrar en el Título IV del Libro II que regula la investigación y sanción del acoso sexual.

Para el caso que así sea, la ley otorga un beneficio al empleador. Indica el artículo 154 № 12 , inciso $2^{\circ}$ que "En el caso de las denuncias sobre acoso sexual, el empleador que, ante una denuncia

\footnotetext{
196 Ver sentencia de Corte de Apelaciones de Valparaíso, de 3.03.2003, Rol N 773-02, confirmada por la Sentencia de la Corte Suprema, de 9.04.2003, Rol N².704-02.

197 Lizama, Luis; Ugarte, José Luís, op.cit. (n. 149), p. 22.

198 Código práctico de conducta para combatir el acoso sexual en el trabajo. Comisión Europea. Diario Oficial L 49 del 24 de febrero de 1992.

199 Jiménez Trejo, Patricio. "Las obligaciones del empleador frente al acoso sexual". En su: El acoso sexual en la empresa. Análisis de la ley 20.005. Santiago, Chile: Lexis Nexis, 2005. pp. 52 y ss.
} 
del trabajador afectado, cumpla íntegramente con el procedimiento establecido en el Título IV del LIBRO II, no estará afecto al aumento señalado en la letra c) del inciso primero del artículo 168".

De la legislación se desprende un claro procedimiento con diversas etapas. Indica Jiménez que tales son: a) La etapa de la denuncia, por la que se garantiza el acceso de parte de la supuesta víctima, bajo las formalidades impuestas por la ley; b) La etapa de medidas de resguardo, una vez conocida la denuncia, en cuanto se persigue el amparo de la supuesta víctima; c) La etapa de la investigación, en los casos en que ésta la asume el empleador, o su remisión a la autoridad administrativa, y d) La etapa de conclusión y de adopción de medidas ${ }^{200}$.

\section{a) Etapa de denuncia}

Tal etapa está regulada en el artículo 211-A del Código del Trabajo, que indica que la persona afectada deberá formular un reclamo por escrito a la dirección de la empresa, establecimiento o servicio o a la respectiva Inspección del Trabajo, debiendo esta decidir si llevará la investigación mediante el canal formal de la empresa o bien ante la inspección del trabajo.

En directa relación con lo anterior tiene vigencia lo dicho en el artículo $154 \mathrm{~N}^{\circ} 12$, ya que el empleador podrá señalar en el reglamento interno qué cargos dentro de la organización de la empresa podrán ser receptores de la denuncia, como por ejemplo el Jefe de Personal, el Gerente de Recursos Humanos o el Gerente del área en la cual se desempeña el trabajador, entre otros.

Sobre el punto la jurisprudencia ha dicho que debe existir certeza y claridad ante quien recurrir ante tal situación de modo que alusiones genéricas no satisfacen tal requisito ${ }^{201}$.

\section{b) Etapa de medidas de resguardo}

Señala sobre el punto el artículo Art. 211-B del Código del Trabajo, que una vez recibida la denuncia, el empleador deberá adoptar las medidas de resguardo necesarias respecto de los involucrados, tales como la separación de los espacios físicos o la redistribución del tiempo de jornada, considerando la gravedad de los hechos imputados y las posibilidades derivadas de las condiciones de trabajo.

En caso que la denuncia sea realizada ante la Inspección del Trabajo, ésta sugerirá a la brevedad la adopción de aquellas medidas al empleador.

Respecto de las medidas, estas deben ser interpretadas en armonía con el artículo 12 del Código del Trabajo. Se ha dicho que en "un examen más detenido del ejercicio de esta potestad por el empleador, nos llevará a concluir que éste tendrá como límite el respeto de los derechos fundamentales y los derechos irrenunciables del trabajador imputado"202.

\footnotetext{
200 Ibid., pp. 60 y ss.

201 "Que la parte pertinente del Reglamento interno de la empresa, que fue incorporado a la audiencia, deja en claro que la empresa informa el derecho a denunciar por escrito los hechos definidos como "acoso sexual", sin embargo no establece de un modo claro a quien se debe recurrir para efectuar la denuncia respectiva ya que alude a la "gerencia y/o administración superior de la empresa", percatándose éste juez con motivo de la absolución de posiciones que no existe, por el ejemplo, el cargo de Gerente de Recursos Humanos, pero sí el de "subgerente" que tiene facultades de administración. Esta situación cobra relevancia, toda vez que tratándose de denuncias sobre hechos tan comprometidos con la honra y dignidad de las personas no es fácil decidirse a denunciar y por lo tanto se debe tener certeza que lo hago en la forma y con la persona correcta. Por lo demás los testigos de la demandante, en especial el sr. Bustos, señalaron que no existía conocimiento por parte de los trabajadores de qué hacer frente a un hecho de este tipo." Sentencia $2^{\circ}$ Juzgado de Letras del Trabajo de Santiago, 16 de noviembre de 2009, RIT T-4-2009.
}

202 Lizama, Luis; Ugarte, José Luís, op.cit. (n. 149), p. 39. 
Álvaro Eduardo Domínguez Montoya, Patricio Eleodoro Mella Cabrera, Teodoro Rodolfo Walter Díaz / El acoso en el trabajo: algunos aspectos doctrinarios, jurisprudenciales y legales del acoso moral y sexual en Chile

\section{c) De la investigación}

La investigación podrá ser realizada, por la Inspección del Trabajo o por la Empresa.

En el caso que sea la Empresa, el empleador dispondrá la realización de una investigación interna de los hechos o, en el plazo de cinco días, remitirá los antecedentes a la Inspección del Trabajo respectiva.

Si se optare por una investigación interna, esta deberá constar por escrito, ser llevada en estricta reserva, garantizando que ambas partes sean oídas y puedan fundamentar sus dichos, y las conclusiones deberán enviarse a la Inspección del Trabajo respectiva.

Esta investigación, bajo cualquier circunstancia deberá concluirse en el plazo de treinta días.

En el caso que quien lleve la investigación sea la Dirección del Trabajo, se rige por procedimiento de investigación especial de denuncias por acoso sexual regulado mediante Orden de Servicio $\mathrm{N}^{\circ} 8$, de 3 de julio de 1997.

\section{d) Sanciones}

Las posibles sanciones a que puede ser objeto el trabajador acosador se debe regir expresamente por las establecidas en el Reglamento Interno respecto del acoso sexual, aunque conforme al artículo $154 \mathrm{~N}^{\circ} 10$ del Código del Trabajo, estas solo pueden ser amonestación verbal, amonestación por escrito y multa de hasta el $25 \%$ de la remuneración diaria del trabajador. Podrá también optar el empleador por la separación física definitiva de los trabajadores involucrados mediante la modificación unilateral del lugar donde debe prestar sus servicios el responsable de acoso sexual. De igual modo, el empleador puede disponer la alteración de la distribución de la jornada laboral respecto del acosador, a fin de evitar que trabaje junto a la víctima. Igualmente, y como medida más grave, el empleador podrá despedir, de conformidad al artículo $160 \mathrm{~N}^{\circ} 1$ letra b) del Código del Trabajo, al trabajador responsable de las conductas constitutivas del acoso sexual si los hechos son especialmente graves y resultan comprobados en el curso de la investigación. Claramente todas estas medidas deben realizarse con el objeto de resguardar y proteger al trabajador o trabajadora afectada.

Respecto de la impugnación de dichas medidas o sanciones, la ley nada señala por lo que se deberá regirse por las reglas generales en materia de sanciones.

\subsubsection{Termino de la relación laboral por acoso sexual}

En materia de acoso sexual se configuran dos hipótesis de término de la relación laboral, ya sea esta por voluntad del empleador mediante las formula de un despido disciplinario sancionando al trabajador acosador o bien por iniciativa del trabajador acosado, mediante la fórmula del despido indirecto.

\section{a) Despido disciplinario por conductas de acoso sexual}

Actualmente se contempla como causal de despido disciplinario que pone término al contrato de trabajo sin derecho a indemnización alguna cuando el empleador invoca que se ha producido por el trabajador una conducta de acoso sexual (Artículo $160 \mathrm{~N}^{\circ}$ 1, letra b) del Código del Trabajo).

En tal caso dicha causa se va regir por las reglas propias de este tipo de despido, por lo que el empleador deberá probar en juicio que efectivamente la conducta es grave (por sí lo es la imputación) y que se encuentre debidamente comprobada. 
En tal situación deberá comunicarlo por escrito al trabajador, personalmente o por carta certificada enviada al domicilio señalado en el contrato, expresando la o las causales invocadas y los hechos en que se funda, teniendo un plazo de 3 días hábiles para informar. Deberá enviarse copia del aviso mencionado a la respectiva Inspección del Trabajo, dentro del mismo plazo.

Dicha causal de despido no da derecho a indemnizaciones por término de la relación laboral. El trabajador despedido tendrá un plazo de 60 días para impugnar el despido por dicha causal el cual puede verse suspendido por interposición de reclamo ante la inspección del trabajo el cual no podrá superar 90 días. En el caso que los tribunales de justicia estimen que dicha causal es indebida, el juez condenara al empleador al pago de la indemnización por término de la relación laboral esto es indemnización sustitutiva de aviso previo y por años de servicio, incrementando la indemnización por años de servicios en un $80 \%$ y si el despido fuere además declarado carente de motivo plausible por el tribunal, la indemnización se incrementará en un $100 \%$.

En el caso de las denuncias de acoso sexual, el empleador que haya cumplido con su obligación de estipular en el reglamento interno de orden, higiene y seguridad, las normas que se deben observar para garantizar un ambiente laboral digno y de mutuo respeto entre los trabajadores y haya tramitado la denuncia sobre acoso sexual, de conformidad al procedimiento establecido en el Título IV del Libro II del Código del Trabajo, no estará afecto al recargo de indemnización a que hubiere lugar, en caso de que el despido sea declarado injusto, indebido o improcedente.

Sobre las reglas procesales ante una eventual impugnación, estimamos que igual podrá el trabajador demandar mediante las formalidades del procedimiento de tutela ya que con ocasión del despido dicha imputación podría lesionar eventualmente derechos fundamentales cautelados por tal procedimiento. Igualmente creemos que el trabajador podría demandar daño moral con independencia de las indemnizaciones reguladas a propósito del procedimiento tutela ${ }^{203}$.

\section{b) Autodespido frente a conductas de acoso sexual}

Una segunda opción es aquella relativa al autodespido por incumplimiento de las obligaciones patronales. La situación que justifica esta vía se encuentra en que no es admisible obligar al trabajador continuar con el vínculo laboral si es objeto de un trato constitutivo de acoso sexual pudiendo entonces poner término al contrato fundado en la causal 160 № 1 letra b) del Código del Trabajo, siempre y cuando ello sea obra del empleador. Si se tratara de un acoso horizontal, la terminación solo podría ajustarse a la causal de incumplimiento grave que regula el $160 \mathrm{~N}^{\circ} 5$ y 7 del Código del Trabajo, argumentando la violación de la obligación de seguridad y salud que pesa sobre el empleador ${ }^{204}$.

En el caso que se acepte el despido, el empleador estará obligado a realiza el pago de aquellas indemnizaciones reguladas en el artículo 168 del Código del Trabajo, pudiendo tener un recargo de un $50 \%$ y $80 \%$ según la causal invocada. Estimamos que igualmente el trabajador podrá, además como lo indicamos anteriormente, demandar las indemnizaciones por daño moral incluso acumularlas a las indemnizaciones punitivas del procedimiento de tutela en el caso que este sea compatible con la figura del autodespido.

Ahora si el tribunal rechaza la demanda, se entenderá que el trabajador renuncio a su puesto de trabajo. Se regula expresamente en el artículo 171 del Código del Trabajo que si el trabajador

203 Sobre la posibilidad de demandar en sede laboral ver: Gamonal Contreras, Sergio, El daño moral... (n. 128); Gamonal CONTRERAs, Sergio, "Evolución del daño moral... (n. 128). Véase reciente fallo que reconoce dicha hipótesis en materia laboral: Corte Suprema, 7 de noviembre de 2014, ROL 2746-2014.

204 En este sentido Lizama, Luis; UgarTe, José Luís. op.cit. (n. 149), 50 y ss. 
Álvaro Eduardo Domínguez Montoya, Patricio Eleodoro Mella Cabrera, Teodoro Rodolfo Walter Díaz / El acoso en el trabajo: algunos aspectos doctrinarios, jurisprudenciales y legales del acoso moral y sexual en Chile

hubiese invocado la causal de la letra b) del número 1 del artículo 160 , falsamente o con el propósito de lesionar la honra de la persona demandada y el tribunal hubiese declarado su demanda carente de motivo plausible, estará obligado a indemnizar los perjuicios que cause al afectado. En el evento que la causal haya sido invocada maliciosamente, además de la indemnización de los perjuicios, quedará sujeto a las otras acciones legales que proceda. En tal situación según las reglas procesales vigentes se deberá deducir demanda reconvencional al momento de contestar la demanda por parte de la empresa.

\subsubsection{Acoso sexual y funcionarios públicos}

Respecto de la situación de acoso sexual y los funcionarios públicos, actualmente existen normas expresas que regulan tal situación. El Estatuto Administrativo (Ley $\mathrm{N}^{\circ} 18.843$ ), establece una prohibición para los funcionarios públicos y una causal de destitución, ambas referidas al acoso sexual.

El artículo 84 letra 1 (sic) de la ley 18.843 indica que "El funcionario estará afecto a las siguientes prohibiciones: 1) Realizar cualquier acto atentatorio a la dignidad de los demás funcionarios. Se considerará como una acción de este tipo el acoso sexual, entendido según los términos del artículo $2^{\circ}$, inciso segundo, del Código del Trabajo, y la discriminación arbitraria, según la define el artículo $2^{\circ}$ de la ley que establece medidas contra la discriminación".

Igualmente en el artículo 125 del referido texto, se contempla como causal de destitución infringir el artículo 84 letra 1) ya indicado.

\subsubsection{Tutela del acoso sexual}

Respecto de la tutela hay que distinguir una serie de oportunidades y mecanismo jurídicos para la tutela judicial y administrativa del acoso sexual.

\section{a) Acoso sexual e Inspección del Trabajo}

Una de las primeras acciones disponibles es recurrir ante los organismos administrativos correspondiente denunciando la situación acoso sexual sufrida dentro de la empresa, para lo cual la Inspección del Trabajo efectuará una investigación regida por el actual Título IV del Libro II del Código del Trabajo que regula la investigación y sanción del acoso sexual y por procedimiento de investigación especial de denuncias por acoso sexual regulado mediante Orden de Servicio $\mathrm{N}^{\circ} 8$, de 3 de julio de 1997.

En tal supuesto no se debe olvidar sobre el punto la presunción de que gozan las actuaciones realizadas por los Inspectores del Trabajo. En efecto, el artículo 23 del D.F.L. No 2 de 1967, del Ministerio del Trabajo y Previsión Social, disponen que "Artículo $23^{\circ}$ Los Inspectores del Trabajo tendrán el carácter de ministros de fe respecto de todas las actuaciones que realicen en el ejercicio de sus funciones, dentro de las cuales podrán tomar declaraciones bajo juramento.

En consecuencia, los hechos constatados por los Inspectores del Trabajo y de los cuales deban informar de oficio o a requerimiento, constituirán presunción legal de veracidad para todos los efectos legales, incluso para los efectos de la prueba judicial" lo que para efectos probatorios e indiciarios es relevante.

Por lo demás debemos recordar que de conformidad al artículo 486 del Código del Trabajo, existe un mandato legal a la Inspección del Trabajo el cual ordena que en aquellos casos en que si actuando dentro del ámbito de sus atribuciones y sin perjuicio de sus facultades fiscalizadoras, 
la Inspección del Trabajo toma conocimiento de una vulneración de derechos fundamentales, deberá denunciar los hechos al tribunal competente y acompañar a dicha denuncia el informe de fiscalización correspondiente. Esta denuncia servirá de suficiente requerimiento para dar inicio a la tramitación de un proceso conforme a las normas del procedimiento de tutela. La Inspección del Trabajo podrá hacerse parte en el juicio que por esta causa se entable.

No obstante, la Inspección del Trabajo deberá llevar a cabo, en forma previa a la denuncia, una mediación entre las partes a fin de agotar las posibilidades de corrección de las infracciones constatadas.

b) El acoso sexual laboral y el procedimiento de tutela de derechos fundamentales

Atendido que la conducta de acoso sexual constituye una lesión a derechos fundamentales del trabajador, una opción de tutela procesal es la utilización del procedimiento de tutela de derechos fundamentales, contemplado en los arts. 485 y siguientes del Código del Trabajo.

Este procedimiento presenta ventajas para la víctima de acoso, las cuales pueden sintetizarse en: a) La preferencia de tramitación contemplada en el artículo 488 del Código del Trabajo; b) La indemnización adicional no inferior a seis ni superior a once remuneraciones mensuales señalada en el precepto 489 ; c) La reincorporación del trabajador en el caso del despido discriminatorio grave, autorizado en el mismo precepto; d) La facultad del juez de ordenar, en la primera resolución, la suspensión de los efectos del acto impugnado, constituyendo ésta una resolución de carácter cautelar, y que se consagra en la regla 492; e) El alivio probatorio en favor del denunciante indicado en el precepto $493 \mathrm{y}$; f) la posibilidad de obtener la reparación de los daños morales, según la interpretación de la norma 495, No 3 del Código del Trabajo, al expresar “incluidas las indemnizaciones que procedan".

En tal caso, la acción de tutela tendrá por objeto obtener el cese de la conducta hostigatoria en la hipótesis que la relación laboral este vigente, y si ella es ocultada bajo la excusa de un despido disciplinario justificado, el trabajador afectado podrá reclamar del despido con ocasión de la vulneración de derechos fundamentales autorizado en el art. 489 del Código del Trabajo, pudiendo solicitar las indemnizaciones típicas y una adicional que puede fijarse en el rango de seis a once remuneraciones mensuales o dependiendo del derecho infringido la reincorporación.

De igual forma, creemos que en el caso que el trabajador estime necesario ejercer la acción por despido indirecto contemplada en el artículo 171 del Código del Trabajo, también podrá verse beneficiado de dichas formas procesales, por cuanto creemos que el canal idóneo de sustanciación de dichos intereses y derechos se hace mediante el procedimiento destinado a la infracción de derechos fundamentales, por cuanto la esencia justificadora del instituto de acoso sexual recae en los derechos fundamentales inespecíficos del trabajador. Sobre el punto nos remitimos a los comentarios sobre la compatibilidad de esta acción y el procedimiento de tutela respecto del acoso laboral.

c) El acoso laboral y el procedimiento de aplicación general

Si bien el hostigamiento constitutivo de acoso sexual implica necesariamente la lesión a alguno de los derechos fundamentales del trabajador, lo lógico e idóneo es que el mecanismo procesal para su tutela inhibitoria y resarcitoria sea la acción de tutela de derechos fundamentales mediante las formas establecidas para el procedimiento de tutela de derecho fundamentales indicado -no obstante las observaciones indicadas respecto del autodespido-, lo cual no impide que la víctima opte por las acciones típicas que se contemplan en el Código del Trabajo y que en 
Álvaro Eduardo Domínguez Montoya, Patricio Eleodoro Mella Cabrera, Teodoro Rodolfo Walter Díaz / El acoso en el trabajo: algunos aspectos doctrinarios, jurisprudenciales y legales del acoso moral y sexual en Chile

consecuencia no sea necesario invocar el procedimiento de tutela laboral antes mencionado, sin mencionar obviamente la poco utilidad práctica que conlleva tal opción.

Dicha hipótesis si bien no es aconsejable por no desplegar la virtualidad protectora de la acción de tutela, puede ser útil en la medida que se invoque frente un despido injustificado -en su amplia expresión- o bien como forma procesal para tramitar una acción de auto despido si como consecuencia del acoso laboral se produce un incumplimiento o infracción contractual contemplado en el artículo 171 en relación al $160 \mathrm{~N}^{\circ} 5^{\circ}$ y $7^{\circ}$ del Código del Trabajo.

\section{1) El caso del despido}

En esta hipótesis, aun cuando el trabajador estime que el despido que invoca el empleador tiene como antecedente conductas de hostigamiento sexual pero que por problemas probatorios no es posible acreditar, bien puede reclamar del despido ilegal o indebido sin acudir a la tutela laboral ${ }^{205}$ o bien acudir de manera principal a la misma y ejercer subsidiariamente la acción de despido injustificado en su más amplio termino. Esta postura puede explicarse por una insuficiencia probatoria respecto de la lesión del derecho constitucional, que no concurre respecto de la prueba del cumplimiento por parte del trabajador de la conducta invocada para poner término a su contrato por parte de su empleador, haciendo más viable el reclamo judicial conforme al art. 168 del Código del Trabajo, pudiendo demandar además una acción resarcitoria de perjuicio morales ${ }^{206}$.

\section{2) En relación al autodespido}

Esta vía sin duda puede descartar la duda interpretativa acerca de la imposibilidad de unir el despido indirecto a la acción de tutela laboral, y dado el principio de especialidad que rige la tutela, forzoso sería utilizar al procedimiento de aplicación general ${ }^{207}$. La situación que justifica esta vía se encuentra en que no es admisible obligar al trabajador continuar con el vínculo laboral si es objeto de un trato humillante, constitutivo de acoso, pudiendo entonces poner término al contrato fundado en la causal 160 No 1 letra b) del Código del Trabajo, siempre y cuando ello sea obra del empleador. Si se tratara de un acoso horizontal o ascendente, la terminación solo podría ajustarse a la causal de incumplimiento grave que regula el 160 No 5 y 7 del Código del Trabajo, argumentando la violación de la obligación de seguridad y salud que pesa sobre el empleador.

\footnotetext{
205 En relación a un despido, el tribunal resuelve "Que en este mismo orden de ideas lo que en opinión de la Corte se puede inferir, en primer término, que las situaciones de reproche de la empleadora carecían de asidero, por ejemplos, los atrasos imputados se encuentran autorizados, el ingreso de computador personal del actor, fue para cumplir con las labores encomendadas, y en segundo lugar, que se puede concluir que la empleadora no estaba a gusto con los servicios aportados por el actor". Corte de Apelaciones de Santiago, Rol No 858-2010, 25 de enero de 2011.

206 Ver sobre el punto Gamonal Contreras, Sergio. El daño moral en... (n. 128); Gamonal Contreras, Sergio, "Evolución del daño moral... (n. 128). Véase reciente fallo que reconoce dicha hipótesis en materia laboral. Corte Suprema, 7 de noviembre de 2014, ROL N $2746-2014$

207 En la sentencia señalada en el número anterior, el tribunal acoge el despido indirecto propuesto en forma subsidiaria, señalando que no es procedente alegar el despido indirecto en una tutela laboral. Los hechos constitutivos de acoso correspondían a presiones para aceptar rebajas de sueldo, privarlo de acceso a algunos lugares y al libro de asistencia, amenazas directas, eliminación de bonos, gratificaciones, etc. Corte de Apelaciones de Santiago, Rol No 858-2010, 25 de enero de 2011.
} 


\subsubsection{La prueba del acoso sexual}

Existe uniformidad en la jurisprudencia que debido a la naturaleza de los hechos que configuran la hipótesis de acoso sexual, suele:

"Ser de muy difícil prueba para las víctimas, por una parte porque en ocasiones estas suelen normalizarse, y entenderse por los trabajadores, especialmente aquellos menos capacitados o instruidos, como un elemento más del vínculo de subordinación y dependencia y de la potestad de mando del empleador, y porque además, estilos de mando caracterizados por el abuso y la discriminación, suelen tener entre sus consecuencias el causar temor a los trabajadores" 208 .

Haciendo eco de lo anterior se ha dicho que:

“Tratándose de actos constitutivos de acoso sexual no resulta lógico exigir a la víctima elementos de convicción categóricos y de naturaleza tal que conduzcan, sin lugar a dudas, al establecimiento de la figura que se estudia; por el contrario, atendido los bienes jurídicos que se intenta proteger a través de su creación, indiscutiblemente, los sentenciadores han de razonar fundamentalmente sobre la base de indicios emanados de las probanzas aportadas y sobre las consecuencias o efectos demostrables en la persona de la víctima. En la especie, como ya se dijo, la prueba aportada logra formar la convicción del tribunal acerca de la efectividad de los hechos que sustentan la causal de caducidad invocada por la demandante"209.

Creemos que en tal sentido debe darse una mayor flexibilidad en las probanzas a rendir en los casos de acoso sexual, necesariamente por la naturaleza de los hechos y frente al frágil escenario probatorio ante el cual se ve expuesto el trabajador o trabajadora afectado, siendo fundamental que en tal supuesto que las acciones de autodespido sean tramitadas por el procedimiento de tutela el cual permite aliviar mediante la prueba indiciaria la actividad probatoria del trabajador.

\section{OPINIONES CONCLUSIVAS RESPECTO DEL ACOSO MORAL Y SEXUAL}

En general se puede sostener que las conductas de acoso laboral y sexual antes analizadas admiten ser estudiadas desde un triple punto de vista, esto es, como una hipótesis de incumplimiento del contrato de trabajo, lo que implica establecer cuál es la obligación incumplida; o vincular el acoso a una vulneración de un derecho fundamental, lo que según la doctrina puede afectar variados derechos fundamentales, y destacadamente, la dignidad, la integridad psíquica y física, y la intimidad del trabajador; finalmente, puede analizarse como un caso de infracción a la legislación laboral o ilícito laboral, lo que acarrea la aplicación de la teoría del derecho sancionatorio punitivo

\footnotetext{
208 Sentencia del $2^{\circ}$ Juzgado de Letras del Trabajo de Santiago, 16 de abril de 2010, RIT T-16-2010.

209 Sentencia Corte de Apelaciones de Santiago, 27 de mayo de 2008, ROL N ${ }^{\circ}$ 4475-2007. No obstante dicha sentencia es revocada por la Corte Suprema, 11 de septiembre de 2008, ROL No 3868-2008.
} 
Álvaro Eduardo Domínguez Montoya, Patricio Eleodoro Mella Cabrera, Teodoro Rodolfo Walter Díaz / El acoso en el trabajo: algunos aspectos doctrinarios, jurisprudenciales y legales del acoso moral y sexual en Chile

del Estado, cuestión que no fue objeto de este trabajo, y que sin embargo estimamos de relevancia que ello se aborde.

Desde el punto de vista de su evolución en el derecho del trabajo, tanto uno y otro acoso, antes de su reconocimiento legislativo mediante la ley 20.005 del año 2005 y la ley 20.607 del 8 de agosto de 2012, era una conducta reprochable que se resolvía en sede laboral a través de los casos de despido injustificado y el despido indirecto, y más lejanamente, a través del recurso de protección, mecanismo que en la práctica no era utilizado por los trabajadores por el temor al despido.

$\mathrm{La}$ incorporación de la regulación legal respecto de las conductas de acoso, en sus dos vertientes, en fechas distintas según se aprecia desde la entrada en vigencia de los cuerpos legislativos que lo sancionaron, no implica un estatuto novedoso como quedó plasmado en la tramitación de las aludidas leyes, pero contribuye a esclarecer su concepto, particularmente con la exigencia de que la conductas pueden asumir una forma de agresión $\mathbf{u}$ hostigamiento, plasmando la gravedad de ella, a lo que debe unirse que no es necesaria la repetición de ellas en el caso del acoso sexual, solución que no es igual en el acoso moral, en que la reiteración de la conducta viene impuesta por la ley, debiendo la jurisprudencia dándole contenido a estos requisitos.

En el escenario actual, la tutela judicial de ambos acosos en sede laboral, admiten la protección a través del procedimiento general de aplicación, el autodespido y destacadamente el Procedimiento de Tutela Laboral contemplado en el párrafo $6^{\circ}$ del Libro $\mathrm{V}$ del Código del Trabajo, artículos 485 y siguientes. Igualmente puede acudirse al recurso de protección, pero como se dijo, dicha acción no ha constituido un mecanismo confiable para el trabajador.

En el caso del procedimiento de tutela laboral, se observan variados pronunciamientos judiciales respecto de los requisitos y fórmula de reparación de las conductas de acoso, distinguiéndose según si el contrato está vigente o si el acoso acarrea el despido del trabajador. En el primer caso la reparación se logra con las medidas que autoriza la sentencia de tutela laboral en el artículo 495 del Código del Trabajo, y la indemnización de los daños morales. En el caso del acoso que acarrea el despido, la reparación puede abarcar desde el reintegro (si el acoso es constitutivo de un despido discriminatorio grave) hasta la indemnización adicional de seis a once remuneraciones mensuales, según la fórmula que se describe en el art. 489 del Código del Trabajo.

Por último, es interesante destacar como las conductas de acoso moral y sexual en el ámbito laboral se han ido perfilando como un caso de vulneración de derechos fundamentales, lo que ha ido configurando una jurisprudencia más robusta respecto de su contenido, requisitos y reparación.

\section{BIBLIOGRAFÍA}

Aвajo Olivares, Francisco Javier. Mobbing: El acoso psicológico en el ámbito laboral. Bucnos Aires, Argentina: Editorial Depalma, 2004.

Barbagelata, Héctor-Hugo. Derecho del Trabajo. Montevideo, Uruguay: Fundación de Cultura Universitaria, Tomo I, 2007.

Bayzos Grau, Antonio. "En torno al Estatuto de los Trabajadores: la prohibición de inquirir sobre la ideología, creencias y vida privada del trabajador". En: Lecciones del derecho del trabajo en homenaje a los profesores Bayón Chacón y del Peso y Calvo. Madrid, Espańa: Facultad de Derecho de la Universidad Complutense, 1980.

Begoña Pernas (et al.). La dignidad quebrada. Las raices del acoso sexual en el trabajo. Madrid, España: Fundación $1^{\circ}$ de Mayo Secretaría Confederal de la Mujer CC.OO, Los Libros de la Catarata, 2000.

Brodsky, Carroll. The Harassed Worker. D.C. Health and Company, Lexington, 1976. 
CaAmaño, Eduardo. "El bien jurídico protegido frente a los actos de acoso sexual en el lugar de trabajo", en: Revista de Derecho $\mathrm{N}^{\circ} 25$, pp. 93-114. Valparaíso, Chile: Escuela de Derecho, Pontificia Universidad Católica de Valparaiso, 2004.

CaAmaño, Eduardo. "Acoso Sexual: concepto, clases y bien jurídico protegido". En su: El acoso sexual en la empresa. Análisis de la ley 20.005. Santiago, Chile: Lexis Nexis, 2005.

CaAmaño, Eduardo. El derecho a la no discriminación en el empleo. Santiago, Chile: AbeledoPerrot, 2007.

CaAmaño, Eduardo. "La noción de acoso laboral o mobbing y su reconocimiento por la jurisprudencia en Chile", en: Revista de Derecho, No 37, XXXVII, pp. 215-240. Valparaíso, Chile: Pontificia Universidad Católica de Valparaíso, 2011.

CaAmaño Rojo, Eduardo; Ugarte Cátaldo, José Luis. "El acoso laboral: tutela y prueba de la lesión de los derechos fundamentales", en: Revista Ius et Praxis, Vol. 20, ${ }^{\circ} 1$. Talca, Chile: Facultad de Derecho, Universidad de Talca, 2014.

Calle Fuentes, M.; GonzÁlez Romero; NúNéz Triguero, J.A. Discriminación y acoso sexual a la mujer en el trabajo. Madrid, España: Largo Caballero, 1988.

Cameruynk, G.H.; Lyon- Caen. Derecho del Trabajo. Madrid, España: Editorial Aguilar, 1974.

Cavas MarTínez, Faustino. "El acoso moral en el trabajo (mobbing): Delimitación y herramientas para combatirlo", en: Actualidad Juridica Aranzadi, No 555, pp. 1-7. Madrid, España: Thomson Reuters, 2002.

Chapell, Duncan; Di Martino, Vittorio. Violence at Work. Ginebra, Suiza: OIT, 1998. Correa Carrasco, Manuel; VAldés DE LA VeGA, Berta (Coords.). Los Medios de Tutela frente al Acoso Moral en el Trabajo. Granada, Espańa: Comorales, 2007.

Carrasco Oñate, Celina; Vega López, Patricia. Acoso Sexual en el trabajo, ¿denunciar o sufrir en silencio? Análisis de denuncias. Santiago, Chile: Estudios de Dirección del Trabajo, 2009.

DaEREN, Lieve. La OIT frente al acoso sexual. Santiago, Chile: Documento de trabajo, OIT-ETM, 1998.

Dejours, C. Trabajo y violencia. Cuando la injusticia se hace banal. Madrid, España: Modus Laborandi, 2009.

Escudero Moratalla, Jf.; Poyatos, I.; Matas, G. "Mobbing: análisis multidisciplinar y estrategia legal; adaptado a la ley 26/2003, de 30 de diciembre. Comentarios y formularios". Barcelona, España: Boch, 2004.

Farías, Pamela; Gómez, Marcela. Acoso sexual en el trabajo: de la impunidad a la acción. Aportes al Debate Laboral, $\mathrm{n}^{\circ}$ 7. Santiago, Chile: Departamento de Estudios, Dirección del Trabajo, 1999.

Ferrada Bórquez, Juan Carlos; Watter Díaz, Rodolfo. "La tutela laboral de derechos fundamentales en el código del trabajo o la aplicación del derecho como Arte de Magia" (A propósito de la sentencia de la Excma. Corte Suprema "Monsalve con Muellaje STI S.A"), en: Revista de Derecho, año LXXVIII, pp. 91-11. Concepción, Santiago: Facultad de Derecho, Universidad de Concepción, 2010.

Farley, L. Sexual Shakedown. New York, Estados Unidos: Warner Book, 1978.

Foucault, Michel. La verdad y las formas jurídicas. Barcelona, Espańa: Gedisa, 2005.

Gamonal Contreras, Sergio. Ciudadania en la empresa o los derechos fundamentales inespecificos. Montevideo, Uruguay: Fundación de Cultura Universitaria, 2004.

Gamonal Contreras, Sergio; Prado López, Pamela. El mobbing o acoso mora laboral. Santiago, Chile: Lexis Nexis, 2006.

Gamonal Contreras, Sergio. El daño moral en el contrato de trabajo -2º ed.-. Santiago, Chile: Legal Publishing, 2007.

Guidi Moggia, Caterina. "El acoso moral o psicoterror en el ámbito laboral" (parte I y II), publicados en: Revista Laboral Chilena, Junio-Julio. Santiago, Chile, 2006.

Gamonal. Contreras, Sergio. "Evolución del daño moral por término del contrato de trabajo en el derecho chileno", en: Revista de Derecho, n. 39, pp. 161-176. Valparaíso, Chile: Escuela de Derecho, Pontificia Universidad Católica de Valparaíso, 2012.

Gamonal, Sergio; Guidi, Caterina. Fundamentos de Derecho Laboral. Santiago, Chile: Lexis Nexis, 2008. 
Álvaro Eduardo Domínguez Montoya, Patricio Eleodoro Mella Cabrera, Teodoro Rodolfo Walter Díaz / El acoso en el trabajo: algunos aspectos doctrinarios, jurisprudenciales y legales del acoso moral y sexual en Chile

Heinemann, Peter-Paul. Mobbning-grupvald bland barn och vuxna. Estocolmo, Suecia: Natur och kultur, 1972.

Henríquez, Helia; Riquelme, Verónica. Asedio sexual en el trabajo. Una politica para su erradicación. Temas Laborales $n^{\circ}$ 6. Santiago, Chile: Departamento de Estudios, Dirección del Trabajo. 1997.

Hirigoyen, Marie-France. El acoso moral. El maltrato psicológico en la vida cotidiana. Barcelona, España: Paidós, 1999.

Hirigoyen, Marie- France. El acoso moral en el trabajo. Distinguir lo verdadero de lo falso. Barcelona, España: Paidós, 2001.

JaVILLIER, Jean-Claude. Derecho del Trabajo. Madrid, Espańa: Edición de Instituto de Estudios Laborales y Seguridad Social, 1982.

Javillier, Jean-Claude. Derecho del Trabajo. Montevideo, Uruguay: Fundación de Cultura Universitaria, 2007.

JIMÉNEZ, Patricio. "Las obligaciones del empleador frente al acoso sexual". En su: El acoso sexual en la empresa. Análisis de la ley 20.005. Santiago, Chile: Lexis Nexis, 2005.

Jurado Segovia, Ángel. Acoso Moral en el Trabajo. Madrid, España: Editorial La Ley, 2008.

Leymann, Heinz. "The mobbing Encyclopedia", disponible en www.leymann.se.; The content and development of Mobbing at work; European Journal of Work and Organizational Psychology, 1996, 5 (2), disponible y traducido al español por Francisco Fuentes, en www.ste.uji.es,

Lizama Portal, Luis. Derecho del Trabajo. Santiago, Chile: Lexis Nexis, 2005.

Lizama, Luis; Ugarte, José Luís. Nueva Ley de Acoso Sexual. Santiago, Chile: Lexis Nexis, 2005.

Lorenz, Konrad. El comportamiento animal y humano. Barcelona, España: Plaza \& Janés, 1985.

Lorenz, Konrad. Sobre la agresión: el pretendido mal. Madrid, España: Siglo veintiuno de España, 1985.

Mangarelli, Cristina. “Tendencias del derecho del trabajo", en: Revista Gaceta Laboral, vol. 15, nº 1, pp. 87-100. Venezuela, Caracas, 2009.

Mangarelli, Cristina. "Protección de la vida privada del trabajador en el lugar de trabajo" en: Octavo Congreso Regional Americano del Derecho del Trabajo y de la Seguridad Social. Bogotá, Colombia: Colegio de Abogados del Trabajo, 2010.

Mackinnon, C.A. Sexual Harassment of Working Women:a cases of sex discrimination. New York, Estados Unidos: Yale University press, 1979.

Mella Cabrera, Patricio; Domínguez Montoya, Álvaro. "Conflicto de derechos constitucionales y juicio de tutela laboral en Chile: Estado doctrinal, legal y jurisprudencial”, en: Revista de Derecho, n' XXXIX, vol. 2, pp. 177 219. Valparaíso, Chile: Escuela de Derecho, Pontificia Universidad Católica de Valparaíso, 2012.

Palavecino Cáceres, Claudio. "La protección contra el Acoso Psíquico Laboral en el ordenamiento jurídico chileno", en: Revista de Derecho, vol.17, pp. 63-89. Valdivia, Chile: Facultad de Derecho, Universidad Austral de Chile, 2004.

Palavecino Cáceres, Claudio. "El nuevo ilícito de acoso sexual en el derecho del trabajo chileno", en: Revista de Derecho, n 19, pp. 105-123. Valdivia, Chile: Facultad de Derecho, Universidad Austral de Chile, 2006.

Palomeque, Manuel. Los derechos laborales en la Constitución española. Madrid, España: Centro Estudios Constitucionales, 1991.

Palomeque, Manuel; Álvarez de la Rosa, Manuel. Derecho del trabajo -18 a edición-. Madrid, España: Editorial Centro de Estudios Ramón Areces S.A., 1996.

Pérez Del Río, Teresa. "El acoso sexual en el trabajo: su sanción en el orden social”, en: Relaciones Laborales, $\mathbf{n}^{\circ}$ 2, pp. 181-199. Madrid, España, 1990.

Piñuel y Zabala, Iñaki. Mobbing. Manual de autoayuda. Madrid, España: Aguilar, 2003. 
Álvaro Eduardo Domínguez Montoya, Patricio Eleodoro Mella Cabrera, Teodoro Rodolfo Walter Díaz / El acoso en el trabajo: algunos aspectos doctrinarios, jurisprudenciales y legales del acoso moral y sexual en Chile

Piñuel y Zabala, Iñaki. Mobbing: cómo sobrevivir al acoso psicológico en el trabajo. Bilbao, España: Sal Terrae, 2001.

Planet SEPúlveda, Lucía. "Eficacia del procedimiento de tutela laboral como protección contra el Mobbing en Chile", en: Revista Chilena de Derecho del trabajo y de la Seguridad Social, vol.1 No 1, pp. 93-122. Santiago, Chile: Facultad de Derecho, Universidad de Chile, 2010.

Prado López, Pamela, "Breves reflexiones en torno al mobbing", en: Revista Laboral Chilena, Julio, pp. 91-98. Santiago, Chile, 2005.

Real Academia Española. Diccionario de la lengua española -23ํe.-. Madrid, España: 2013.

Rojas Rrvero, Gloria. Delimitación, Prevención y Tutela del Acoso Laboral. Madrid, España: Bomarzo, 2005.

Rojas, Irene. “¿Por qué se debe legislar sobre el acoso sexual?”, en: Revista Laboral Chilena, Mayo. Santiago, Chile, 1998.

SAGARDoY Bengoechea, Juan. Los derechos fundamentales y el contrato de trabajo. Navarra, España: Editorial Aranzadi, 2005.

Sala Franco, Tomás. Derecho de la prevención de riesgos laborales. Valencia, España: Tirant Lo Blanch, 2004.

SÁnchez, Cruz. Del Acoso Sexual. Aspectos penales. Madrid, España: Thompson Reuters, 2010.

Sierra Herrero, Alfredo. "Acción de tutela laboral y despido indirecto. Comentario a la sentencia "Gómez Cattini con Camilo Ferrón Chile S.A." Segundo Juzgado de Letras del Trabajo de Santiago, 3 diciembre de 2009, RIT T-11-2009, en: Revista de Derecho, Vol. 17, $\mathrm{n}^{\circ} 2$, pp. 325-351. Coquimbo, Chile: Facultad de Derecho, Universidad Católica del Norte, 2009.

Stockdale, Janet. "Acoso Sexual en el Trabajo". En: Firth-Cozanes, J.; West, M.A. (Coords.). Las mujeres en el mundo del Trabajo. Madrid, España: Editorial Morata, 1993.

Ugarte Cataldo, José Luis. Tutela de derechos fundamentales del trabajador. Santiago, Chile: LegalPublishing, 2010.

Ugarte, José Luis. "El acoso laboral: entre el Derecho y la Psicologia", en: Revista de Derecho, n.39, pp. 221-231. Valparaíso, Chile: Escuela de Derecho, Pontificia Universidad Católica de Valparaíso, 2012.

UGARTe, José Luis. El Derecho a la no discriminación en el trabajo. Santiago, Chile: Legalpublishing, 2013.

Uriarte, Óscar; Hernández, Oscar. "Crítica de la Subordinación. Parte I" en: Revista Laboral Chilena, Abril. Santiago, Chile, 2002.

UrrutikoetXea Barrutia, Mikel. Acoso Laboral y Lesión de Derechos Fundamentales. Madrid, España: Boromarzo, 2014. 